Florida International University FIU Digital Commons

6-2-2016

\title{
Ethnographic Investigations of Commercial Aquaculture as a Rural Development Technique in Tamil Nadu, India
}

Brittany L. Kiessling

Florida International University, blkiessling@gmail.com

DOI: $10.25148 /$ etd.FIDC000763

Follow this and additional works at: https:// digitalcommons.fiu.edu/etd

Part of the Asian Studies Commons, Environmental Studies Commons, and the Social and Cultural Anthropology Commons

\section{Recommended Citation}

Kiessling, Brittany L., "Ethnographic Investigations of Commercial Aquaculture as a Rural Development Technique in Tamil Nadu, India" (2016). FIU Electronic Theses and Dissertations. 2560.

https://digitalcommons.fiu.edu/etd/2560 


\section{FLORIDA INTERNATIONAL UNIVERSITY}

Miami, Florida

ETHNOGRAPHIC INVESTIGATIONS OF COMMERCIAL AQUACULTURE AS A

RURAL DEVELOPMENT TECHNIQUE IN TAMIL NADU, INDIA

A dissertation submitted in partial fulfillment of the

requirements for the degree of

DOCTOR OF PHILOSOPHY

in

GLOBAL AND SOCIOCULTURAL STUDIES

by

Brittany Louise Kiessling

2016 
To: Dean John F. Stack, Jr.

School of International and Public Affairs

This dissertation written by Brittany Louise Kiessling, and entitled Ethnographic Investigations of Commercial Aquaculture as a Rural Development Technique in Tamil Nadu, India, having been approved in respect to style and intellectual content, is referred to you for judgement.

We have read this dissertation and recommend that it be approved.

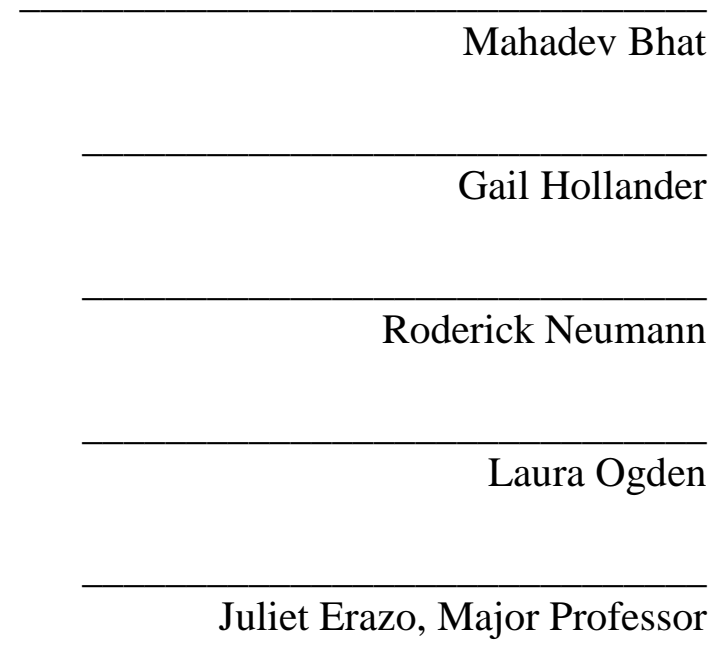

Date of Defense: June 2, 2016

The dissertation of Brittany Louise Kiessling is approved.

Dean John F. Stack, Jr. School of International and Public Affairs

Andrés G. Gil Vice President for Research and Economic Development And Dean of the University Graduate School

Florida International University, 2016 


\section{ACKNOWLEDGMENTS}

There are many people that I would like to thank and acknowledge for supporting and guiding me through this extensive dissertation process. First, I would like to thank my major professor and the members of my dissertation committee for investing the long hours into mentoring me, reading my drafts, and providing such constructive feedback. Professor Laura Ogden served as my advisor and major professor for several years and made sure I navigated the program successfully. She spent long hours working with me on grant proposal submissions and was instrumental in helping me to develop my dissertation project. She stayed on as a committee member even after her transition to Dartmouth College and helped me secure essential funding that allowed me to remain a full-time student. After Professor Ogden moved to Dartmouth College, Professor Juliet Erazo jumped in as my major professor when duty called and made sure that I stayed on track in the midst of the transition between advisors. Professor Erazo patiently read and edited all the iterations of my dissertation, helping me to strengthen my arguments and organize my thoughts. Both professors are role models to me; they have shown me how to persevere in the face of adversity, to be professional while balancing a career and family life, and push myself to become a stronger critical thinker. I aspire to be as motivated, hardworking, and successful as they are. Professor Gail Hollander has also been an integral part of the dissertation committee, stepping in at the last moment and joining the committee even though she had many other obligations. She provided insightful feedback during my proposal defense and had excellent suggestions, inspiring me to think about how commercial aquaculture is an agricultural activity. Professor Roderick Neumann also provided constructive feedback throughout the dissertation 
project and helped to ensure that my project was the best that it could be. I also want to thank him for writing many letters of recommendation for me over the years. Professor Mahadev Bhat recommended contacts in India that allowed me to conduct my exploratory research in India in 2012, helping to make this entire research project possible. He also informed me about the Tamil language lessons available at the local Hindu temple and helped to arrange my participation in the classes, which prepared me for my fieldwork. His expert knowledge is continuously invaluable for this dissertation project.

In addition to my committee members, I would also like to thank Professor Hugh Gladwin, who first welcomed me into the Global and Sociocultural Studies Department. He provided me with a research assistantship that gave me important experience and knowledge about research methods, particularly designing surveys. He has been a source of support and encouragement throughout my graduate career.

I was also fortunate to receive generous funding from the Global and Sociocultural Studies Department and Graduate School at FIU for this dissertation project. The Department provided me with teaching assistantships throughout the years that allowed me to focus on my studies full-time. I especially want to thank Professor Benjamin Smith, the Graduate Program Director, for helping me to secure two final semesters worth of assistantship funding that allowed me to finish the writing phase of the dissertation. The Department also funded a portion of my exploratory research in India through a travel reimbursement grant (2012). I was a recipient of the Graduate 
School’s Dissertation Evidence Acquisition Fellowship (2014) that funded the data collection portion of the dissertation project.

I am grateful to my friends, mentors, and interviewees in India. Aarthi Sridhar at Dakshin Foundation in Bangalore helped sponsor my first trip to India in 2012, giving me the opportunity to begin my research. I am also thankful to the generous people who hosted me during my stay, looked out for me, and made me feel like I was part of their family. Thank you Murali, Fanny, Ann, and Sumathi. I am greatly indebted to Dr. Ramachandra Bhatta who took the time to mentor me as if I was one of his own graduate students and Anna University in Chennai that served as my visa sponsor during my fieldwork in 2014. The bulk of my data collection would also not have been possible without the amazing help from my translator and research assistant, Vasanthakumar. His intimate knowledge of the Nagapattinam District and the aquaculture practices taking place in the region was a valuable asset to the project. He became like a brother to me and made sure that I was safe throughout my work in Poompuhar. His family also accepted me into their home, taught me about village life and ensured that even though I was far from my own family, I had a family in Poompuhar to take care of me. Dr. L. Krishna and the staff of the M.S. Swaminathan Research Foundation Fish For All Centre are another important part of this research in Poompuhar. They hosted me when I first arrived in Poompuhar, shared their facilities, equipment, and data, and even assisted me in hiring Vasanthakumar. I am also grateful to the numerous people in Poompuhar who opened their homes to me and answered my questions. All of them are such beautiful, 
welcoming, and inspiring people. Each of them left a lasting impression on my life and taught me the true meaning of resilience.

I am also grateful to my boyfriend, Alex, who travelled with me to India in 2014 and spent 9 long months away from everything familiar. He was my constant companion through all the struggles that came along with working in a foreign place. He has been supportive and understanding while I have spent late nights and weekends writing and editing this dissertation.

Finally, and most importantly, I would not have been able to achieve as much as I have, without my parents Jay and Diana Kiessling. They have given me never-ending love and guidance. I am so lucky to have such an encouraging family that always sees the best in me, even when I am struggling or doubting myself. I know they worried about me when I travelled to India, going so far from home, but they let me make my own way. I am so thankful that I finally have an end-product to show them. 


\title{
ABSTRACT OF THE DISSERTATION \\ ETHNOGRAPHIC INVESTIGATIONS OF COMMERCIAL AQUACULTURE AS A RURAL DEVELOPMENT TECHNIQUE IN TAMIL NADU, INDIA
}

\author{
by \\ Brittany Louise Kiessling \\ Florida International University, 2016 \\ Miami, Florida \\ Professor Juliet Erazo, Major Professor
}

Since the 1960s, international aid organizations and governments have invested millions of dollars in promoting aquaculture as a way to stimulate local economies and improve food security. India is one such country, incorporating aquaculture research and extension programs as part of their development plans as early as 1971. India’s aquaculture promotion efforts gained momentum in 2004, following the Indian Ocean tsunami of 2004. The government sees aquaculture as a post-disaster development tool and a method to increase community resilience in rural areas of India.

Aquaculture currently constitutes nearly half of global seafood production today. Due to this importance, and the attention such practices receive through funding and extension, many scholars have focused on the social impacts that aquaculture practices have on rural communities. In particular, scholars have investigated the effects of aquaculture on environmental conditions, food security, livelihoods, gender relations, and social conflict. However, more scholarship is needed concerning the historical legacies that have contributed to how aquaculture is promoted and practiced, particularly 
connections to the Green Revolution. Furthermore, there needs to be more research about commercial aquaculture as a post-disaster development strategy.

My research - based on 9 months of ethnographic fieldwork and archival analysis in Tamil Nadu, India - contributes to this body of literature. I synthesized postdevelopment theory with that of environmental risk and vulnerability, building upon the work of scholars such as James Ferguson, Tania Li, and Piers Blaikie. My analysis uncovers large disparities between the goals of aquaculture development programs and actual aquaculture outcomes. I attribute this to the technocratic governance structure of the aquaculture industry, which leads to a lack of engagement and participation between aquaculture managers, researchers, and practitioners. This lack of engagement ultimately makes the communities in which aquaculture is being practiced more vulnerable to anthropogenic and natural disturbances. Additionally, I found that aquaculture practices in the study site are causing significant changes to local agrarian structures, particularly through changes to labor. These changes have implications for social stratification and disempowerment of women. Overall, these findings contribute to the anthropological study of aquaculture as well as to theories of post-development. 


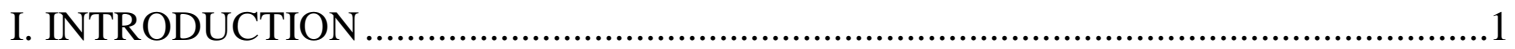

Conceptualization of Key Terms .......................................................................

Situating my Research .............................................................................. 7

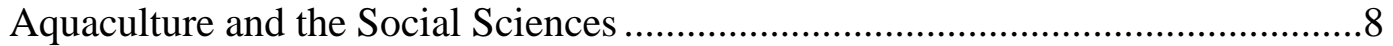

Contributions to Post-Development Studies .......................................................17

Theoretical Frameworks and Outline of the Dissertation ....................................20

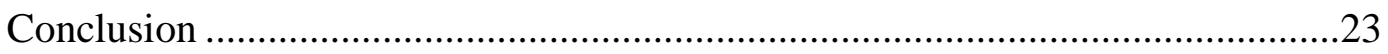

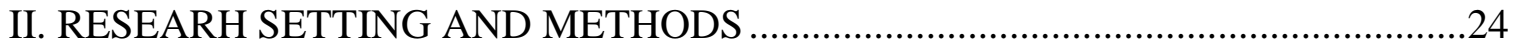

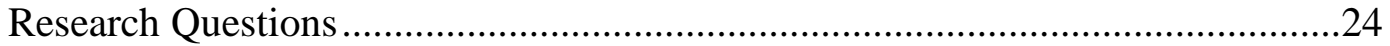

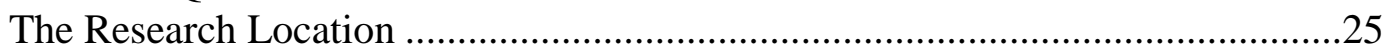

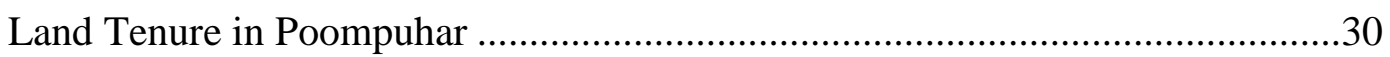

A Site of Rural Development and Recovery......................................................33

Aquaculture Practices within Poompuhar..........................................................35

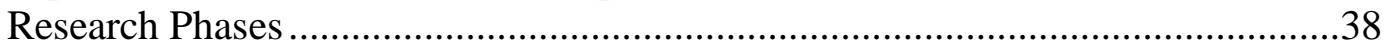

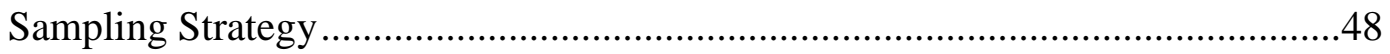

Demographic Overview of Household Surveys ...........................................51

Working with a Translator .........................................................................5

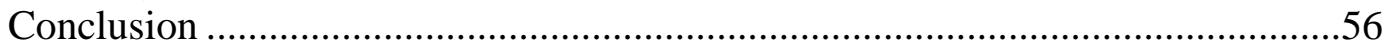

III. ALIGNMENTS BETWEEN THE GREEN REVOLUTION, BLUE

REVOLUTION, AND THE DEVELOPMENT PROJECT ........................................58

Historical and Ideological Underpinnings of the Green Revolution and

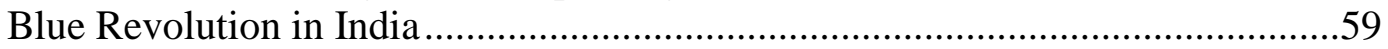

Issues of Food Security and Social Stratification ............................................ 72

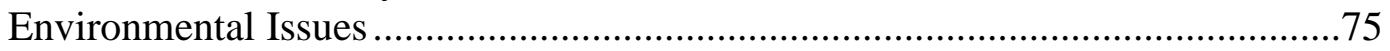

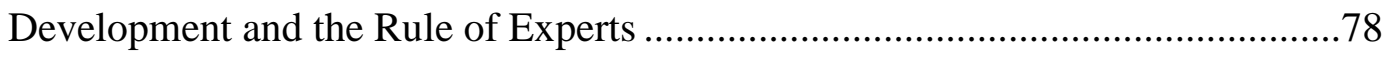

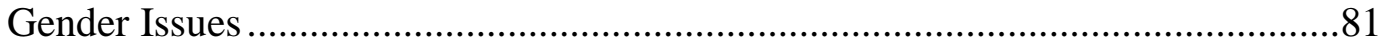

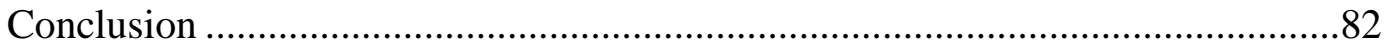

IV. STAKEHOLDER ESTRANGEMENT AND THE CREATION OF

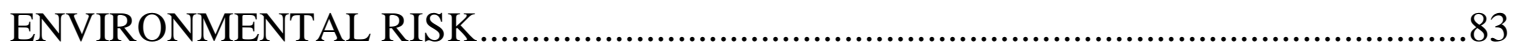

Technocratic Governance and Stakeholder Estrangement ................................85

The Creation of Environmental Risk ...........................................................97

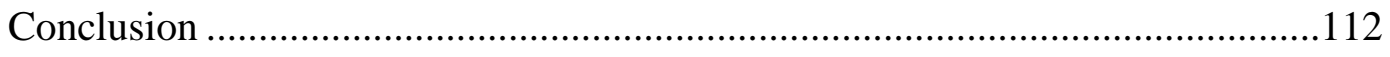

V. COMMERCIAL AQUACULTURE AS POST-DISASTER DEVELOPMENT.......114

Community Damages from the Tsunami .......................................................115

Recovery Responses ..........................................................................118

Aquaculture as Post-Disaster Development...................................................126 
Conclusion

VI. THE AQUACULTURE TRANSITION AND THE GLOBAL INTIMATE:

UNDERSTANDING AGRARIAN CHANGE IN THE WAKE OF COMMERCIAL

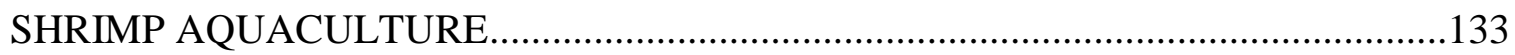

Motivations Behind the Aquaculture Transition.............................................136

The Aquaculture Transition vs. Traditional Agriculture ....................................143

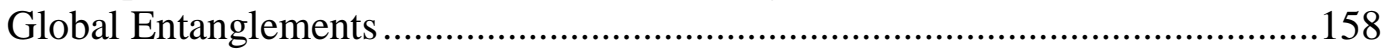

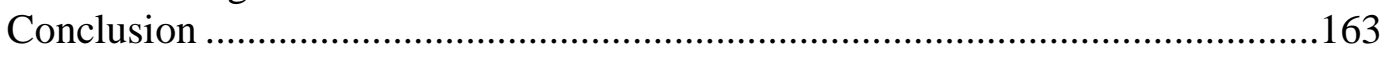

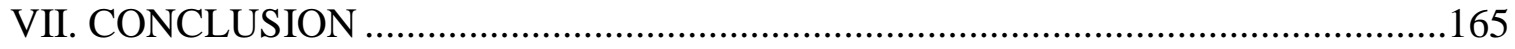

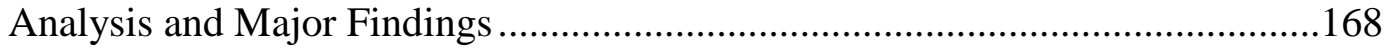

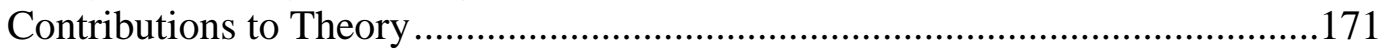

A Note on Generalizability and Future Directions ........................................172

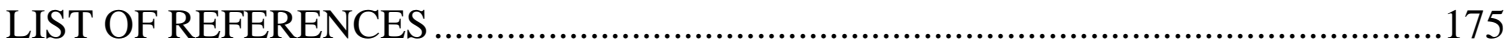

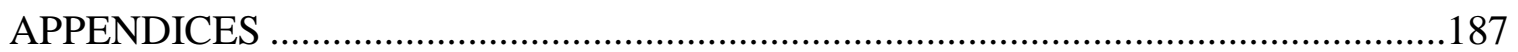

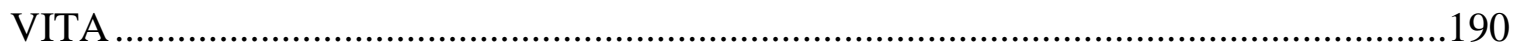




\section{LIST OF FIGURES}

FIGURE

PAGE

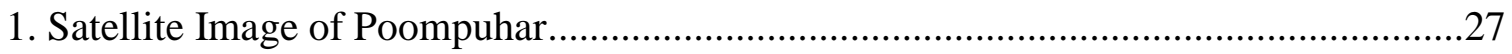

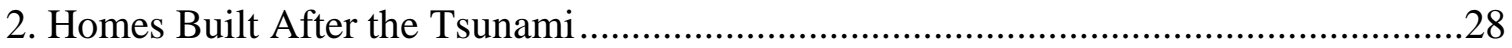

3. The Bureaucratic Hierarchy of Aquaculture in India .............................................40

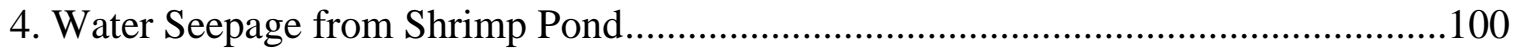

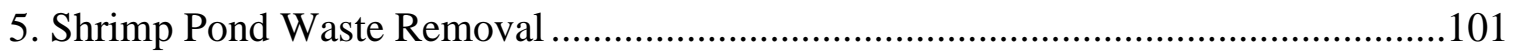

6. Vasanthakumar's Abandoned Ancestral Home ......................................................104

7. Invasive Growth of Prosopis juliflora in Nagapattinam District ..............................105

8. Locations of RGCA Projects in 2014 (map created by RGCA) ................................129

9. Satellite Images of Shrimp Ponds in Poompuhar ...................................................137

10. Scenes of Gendered Labor in Poompuhar ...........................................................156 


\section{ABBREVIATIONS AND ACRONYMS}

\begin{tabular}{|c|c|}
\hline AICRP & All India Coordinated Research Project \\
\hline BCE & Before the Common Era \\
\hline CAA & Coastal Aquaculture Authority \\
\hline CCD & Covenant Centre for Development \\
\hline CIBA & Central Institute of Brackishwater Aquaculture \\
\hline CIFRI & Central Inland Fisheries Research Institute \\
\hline $\mathrm{CP}$ & Charoen Pokphand Foods \\
\hline FAO & Food and Agriculture Organization of the United Nations \\
\hline HYV & High Yield Variety \\
\hline IADP & Intensive Agricultural District Programme \\
\hline ICAR & Indian Council of Agricultural Research \\
\hline ICSF & International Collective in Support of Fishworkers \\
\hline kg & Kilogram \\
\hline L. vannamei & Litopenaeus vannamei \\
\hline MPEDA & Marine Products and Export Development Authority \\
\hline MSSRF & M.S. Swaminathan Research Foundation \\
\hline NFDB & National Fisheries Development Board \\
\hline NGO & Non-Governmental Organization \\
\hline P. monodon & Penaeus monodon \\
\hline RGCA & Rajiv Gandhi Centre for Aquaculture \\
\hline Rs. & Rupees \\
\hline SC & Scheduled Caste \\
\hline SHG & Self Help Group \\
\hline
\end{tabular}




\section{CHAPTER I. INTRODUCTION}

An estimated 50\% of the world's fish and seafood production is from aquaculture (FAO 2016). This means that roughly half of the seafood people consume is actually farmed, rather than captured from wild populations - a fact that most people I speak with are surprised to hear. In the case of the United States, $60 \%$ of the fish and fish products, often farmed, come from “developing” countries such as China, Thailand, and India (FAO 2012). In fact, 21\% of India's marine export products go to the United States, the majority of which is cultured shrimp (FAO 2016).

As important as it is to know where our food comes from, it is also important to understand why our food comes from these specific locations and the processes behind global food networks. One of the driving forces behind the global rise in aquaculture production and the flow of cultured seafood from the developing world to the developed world is its connection with rural development programs. Since the 1960s, aquaculture has been promoted by international aid organizations and governments, particularly in less developed countries, as a way to boost employment opportunities, stimulate local economies, and provide cheaper sources of protein. Scholars often refer to this process as the Blue Revolution. India is an example of a country at the forefront of the Blue Revolution, incorporating aquaculture research and extension programs as part of their development plans as early as 1971- even going as far as to promote aquaculture as an alternative livelihood in areas recovering from the Indian Ocean tsunami of 2004. In this

way, aquaculture is a post-disaster development tool and a method to increase community resilience in rural areas of India. 
Due to the global importance of aquaculture as a food production method, and the attention such practices receive through funding and extension programs, it is not surprising that many studies focus on issues regarding aquaculture. Notable areas of research include investigations of the impact commercial aquaculture practices have on natural resources (Bhatta and Bhat 1998; Dewalt et al. 1996; Shiva and Karir 1996; Vandergeest 2007), changes to food security and livelihoods (Flaherty et al. 2009; Pradhan and Flaherty 2008; Swapan and Gavin 2010), instances of conflict and social mobilization against the aquaculture industry (Aducci 2009; Shiva 2000; Stonich et al.1997; Stonich and Bailey 2000), and issues of gender (Flaherty et al. 2009; Ito 2002; Shiva 2000). However, there are several areas where more research is needed. For example, more attention has been given to the industrialization of agriculture that started around the same time, otherwise known as the Green Revolution. Scores of books have been written about the Green Revolution describing how it unfolded; what sorts of effects it had on household incomes and gender dynamics within families; and how it altered subsistence livelihoods, changed cultural practices, and impacted environmental conditions (Baker and Jewitt 2007; Chakravarti 1973; Cullather 2010; Lipton and Longhurst 1989; Niazi 2004; Perkins 1997; Samaddar 2006; Sobha 2007). The history of the Blue Revolution has inspired much less scrutiny, however, and the social science research that does exist tends to make vague comparisons between the Green and Blue Revolution. But are these two revolutions really that similar? In what ways do they overlap, and in what ways are they different? How are these comparisons significant to understanding the processes behind global networks of food production? This dissertation sets out to answer these questions. 
While commercial aquaculture is widely recognized as a development strategy, particularly in India, there is also a need for more research concerning how practices are incorporated into development programs. Belton and Little (2008) investigated this topic in Thailand and found that aquaculture development is primarily connected to economic processes, particularly trade liberalization and globalization. While their study makes significant contributions to understanding the driving forces behind aquaculture development, there are many unanswered questions, particularly in the context of India. Flaherty et al.'s study (2009) focused on coastal aquaculture in India and does provide important insight into the central government's role in the cultured shrimp export industry. However, their analysis does not fully explain the narratives and ideologies linked with these development processes. This dissertation contributes to these investigations by addressing the following questions. What were the ideological motivations behind the Blue Revolution in India? How is the sector funded and regulated? How is aquaculture extension implemented? What are the goals of these extension programs? What structural changes has such aquaculture development made in communities? This dissertation explores these topics and identifies the various stakeholders involved as well as their unique perspectives.

Another area of research that needs more attention is the use of aquaculture following the Indian Ocean tsunami of 2004. This area of investigation is important because the way in which the Blue Revolution has been implemented in Tamil Nadu has implications for our understanding of disaster recovery efforts. With almost inevitable increases in the frequency of such major climatic events in the coming years due to climate change, what does India's response to the tsunami teach us about governmental 
efforts to reduce risk and improve community resilience? Can governments be effective diversifiers of local economies? Are there unintended consequences of their efforts to do so, and if so, what are they?

Another area of analysis that this dissertation contributes to is how the commercial aquaculture industry, which is both a product of and a driving force behind globalization, entangles within networks at both the global and local scale. In particular, how do commercial aquaculture practices reach across scales in other ways besides food production? What other networks may be involved? Interrogating these entanglements can help scholars to understand the impact that globalization has at different scales; and in the case of this research project, the effect that the global food production process has on the social, economic, and environmental realities of a rural village in India.

My research - based on 9 months of ethnographic fieldwork and archival analysis in Tamil Nadu, India - sought to investigate the connection between rural development initiatives and aquaculture practices in India. Specifically, the following overarching questions guided my research: 1) What types of aquaculture practices are taking place within the research site, particularly as part of rural development efforts in the region, 2) What are the underlying ideologies and assumptions that drive aquaculture development in the research site and what are the goals of such development, 3) How is commercial aquaculture transforming social, economic, and environmental realities within the research site, and 4) How has the community changed since the tsunami of 2004 and the disaster efforts that followed? 


\section{Conceptualization of Key Terms}

There are several important concepts that I engage with throughout this dissertation. Those concepts are “aquaculture,” “aquaculture development,” "livelihood,” “vulnerability,” and “resilience.” In order to clarify my discussion, the following section explains the ways in which I specifically conceptualize these key terms.

\section{Aquaculture and Aquaculture Development}

The term "aquaculture” in the broadest sense, refers to the farming of aquatic organisms either for personal subsistence or in a commercial setting. Several subdivisions of aquaculture exist, depending on the species, water-type, and implementation strategy. For example, the cultivation of fish can be referred to as "pisciculture" and the cultivation of algae or seaweeds can be referred to as "algaculture.” Additionally, "mariculture" is a specialized type of aquaculture that involves the farming of marine organisms in salt-water systems, usually in the open ocean. Throughout this dissertation, I utilize the broadest term, “aquaculture,” but nearly all of the cultivation in the site where I worked consisted of the farming of freshwater fish in ponds and the cultivation of brackishwater shrimp in coastal ponds. I refer to the cases where aquaculture is utilized solely as an income generating activity as “commercial aquaculture” to differentiate from subsistence practices. Additionally, the term “aquaculture development” refers to rural development programs that rely on aquaculture extension and training as the main focus. These programs are meant to expand the aquaculture industry. 


\section{Livelihood}

I conceptualize the term "livelihood" in the same way as Blaikie et al. (1994). They define livelihood as "the command an individual, family or other social group has over an income and/or bundles of resources that can be used or exchanged to satisfy its needs” (Blaikie et al. 1994: 12). Often livelihood is synonymous with a person's job, but it is important to highlight that it encompasses both paid and unpaid labor as well as any other activity that contributes to subsistence.

\section{Vulnerability and Resilience}

Blaikie et al. (1994) defines vulnerability in relation to resilience, conceptualizing it as the characteristics of a system that influence resilience (Blaikie et al. 1994). They explain that "It involves a combination of factors that determine the degree to which someone's life, livelihood, property and other assets are put at risk by a discrete and identifiable event...in nature and in society” (Blaikie et al. 1994: 11). Along these lines, I conceptualize vulnerability as the factors that make human communities less resilient, which in turn puts them at risk for suffering a loss of life, livelihood, property, or other assets.

The concept of resilience, which has its roots in ecology, refers to the capacity for systems to adapt to and resist changes and physical disturbances (Gunderson 2000; Holling 1973). In this dissertation, I apply the term resilience solely to human communities, that is, the ability of human communities to adapt to and resist any type of change to their social, economic, or physical environment. 


\section{Situating my Research}

The state of Tamil Nadu was selected for the research project not only because it has a long history of aquaculture development, but more recently it has been the site of a specific type of development that is aimed at post-disaster recovery following the tsunami of 2004. Out of the thousands of kilometers of India's coastline affected from the tsunami in 2004, Tamil Nadu suffered the most damage and loss of lives (Thirumalai et al. 2007). In order to assist the numerous fishing communities affected, the state government in partnership with international aid organizations provided intensive training in various aquaculture technologies with the goal of improving local economies (Asian Development Bank 2009). As a result, Tamil Nadu has a strong and diverse aquaculture industry. For example, Tamil Nadu is the second largest producer of cultured Pacific White Shrimp out of all the states in India (MPEDA 2015). It also produces a variety of other aquaculture products such as freshwater fish, mud crab, and ornamental saltwater fish. Many research and extension programs that aim to diversify and expand the Indian aquaculture industry while providing alternative livelihood opportunities for community members also support the local aquaculture industry. Consequently, this area provides an ideal location for studying how development practitioners incorporate aquaculture into programs and how these programs transform rural communities.

Poompuhar, a rural village located on the coast of the Bay of Bengal, served as the central site for my research. Many of the residents practice fish and/or shrimp farming, either as primary or supplementary livelihood practices. Poompuhar was one of the hardest hit areas in India during the 2004 tsunami, affecting most of these livelihood practices as well as destroying homes and infrastructure (Thirumalai et al. 2007). Several 
reasons led to my decision to focus the fieldwork in Poompuhar. First, it has a strong aquaculture industry that has been stimulated by development funding, particularly following the 2004 tsunami. Several different types of aquaculture practices take place in the village, such as shrimp farming and fish farming, allowing for a rich investigation of the industry. It also allowed for an analysis of how practices connect to international and local networks as different cultured products reach different types of markets. The second reason that I chose this research site is that it is the location of several prominent aquaculture research and extension stations. This created the opportunity to interview aquaculture technicians, those who are involved in research and extension, in contrast to aquaculture practitioners, those involved in aquaculture as a commercial venture. The third reason why I chose this site is that I had already established connections with key informants from organizations in the region during the exploratory phase of my research.

The processes taking place in Poompuhar entangle with wider networks of development that extend beyond the village and district. To investigate these relationships, I also interviewed technical staff from different institutes and organizations in Chennai, the administrative center for aquaculture research and development in India. Consequently, one phase of the research project took place outside of the main research city of Poompuhar.

\section{Aquaculture and the Social Sciences}

Because commercial aquaculture is promoted by international aid organizations as a way to boost local economies, provide more employment opportunities in rural areas, and improve food security, it is not surprising that a large body of literature exists which 
seeks to measure the success of such programs. In fact, the topic has inspired intense debates among social scientists. Some studies have found that commercial aquaculture can be a desirable alternative livelihood practice, while others have found the opposite. The following section describes the main themes within this debate as well as how this dissertation contributes to the discourse of aquaculture within the social sciences.

\section{Environmental Degradation}

A prevalent topic of discussion involving commercial aquaculture is its negative environmental impacts. For example, many studies link the development of aquaculture to the destruction of mangroves (Bhatta and Bhat 1998; Boyd 2002; Flaherty et al 2009). Commercial aquaculture relies on the production of higher yields, which generally require larger operations than traditional practices. Instead of farming within the mangrove system, aquaculture practitioners, particularly shrimp farmers, cleared away the mangroves and built extensive pond enclosures. This resulted in the loss of important habitats used for spawning, juvenile nurseries, and nesting grounds for many species.

An environmental impact of aquaculture that this dissertation specifically highlights is the contamination of water and soils. My interview data serves to document cases of soil and water changes related to aquaculture practices. Other studies have also documented issues with the contamination of ground water and soils from the practice of commercial shrimp farming (Gujja and Finger-Stich 1996; Pillai et al. 2004; Whitmarsh and Palmieri 2008). These studies demonstrate that shrimp farming, which requires brackish water, causes salinization of surrounding soils and ground water through the seepage of saltwater over time. This decreases the ability for soils to support agricultural 
crops such as rice, forcing farmers to abandon their land. Interviews with community members in Poompuhar, as part of this dissertation, found that similar processes were taking place in the village. My research contributes to the literature not only by providing an additional case study, but also by connecting the issue of salinization with a discussion of risk and vulnerability. I also investigate some of the reasons that this particular environmental problem persists in the aquaculture industry in India, due to the failure of stakeholder engagement.

The loss of biodiversity is another environmental concern associated with commercial aquaculture. Many commercial aquaculture farms use non-native species because they can be more profitable due to faster growth rates, immunity to disease, or high values in international markets (Stickney and McVey 2002). Unfortunately, some studies have linked new varieties of aquaculture products to the loss of native populations. The spread of disease, genetic modification, loss of habitat, and spread of invasive species from commercial aquaculture practices contribute to declines in native aquatic species populations (Hershberger 2002; Shiva 1991; Whitmarsh and Palmieri 2008). While it is important to discover how aquaculture practices affect biodiversity and native populations, more studies are needed that investigate the driving forces behind the use of non-native species and the role of aquaculture research and extension. This dissertation uses data from interviews conducted with aquaculture practitioners and extension workers to explore this topic in further detail.

The environmental problems associated with the commercial aquaculture industry have resulted in the creation of many environmental organizations, which protested the development of aquaculture and pushed for industry bans (Shiva 2000; Shiva and Karir 
1996; Stonich and Bailey 2000; Stonich et al. 1997; Whitmarsh and Palmieri 2008). In some countries, these organizations were successful in lobbying for stricter coastal regulations. For example in India, S. Jagannathan, a Gandhian activist, filed a petition with the Supreme Court of India in 1996 to ban intensive and semi-intensive shrimp farming in ecologically sensitive areas, particularly along the coast. This petition eventually led to the creation of the Aquaculture Authority Act and greater enforcement of the Costal Regulation Zone laws. These laws limit the types of aquaculture activities that can take place and ban any activities in ecologically sensitive areas. Vandana Shiva is another important figure in the aquaculture debate, particularly in her home country of India, where she has led protests against industrial shrimp farming. She is also an outspoken author, writing numerous pieces about the harmful social impacts that industrial aquaculture can have on communities (Shiva 2000).

Scholars such as Matilde Aducci, Susan Stonich, and Conner Bailey have specifically investigated some of the social conflicts arising from the aquaculture industry. For example, Matilde Aducci (2009) investigated the resulting conflict from the entrance of commercial shrimp farming on Chilika Lake in Orissa, India. She found that traditional capture fishermen mobilized with the help of NGOs to protest the shrimp aquaculture industry, particularly corporate-owned shrimp farms. Aducci analyzed this process in terms of class dynamics, and concluded that the privatization of a common resource area led to the reproduction of the dominant "neo-rentier" social class while disempowering the proletariat class. Stonich and Bailey (2000) also studied the social conflict surrounding shrimp farming, particularly the formation of NGOs and transnational advocacy networks against the shrimp industry. They found that these new 
organizations could serve an important role in peasant mobilization, overcoming the weaknesses of local organizations. One aim of this dissertation was to investigate the issue of peasant mobilization and social conflict in Poompuhar given the history of such occurrences in other areas of India. Since the enactment of the Aquaculture Authority and the establishment of Coastal Regulation Zone laws in India, is there still mobilization against the shrimp farming industry? My research found that although some community members complain about the shrimp farming industry, there is no current mobilization against the industry in the area and there is a scarcity of aquaculture related NGOs.

Fortunately, the international community has become aware of the environmental problems associated with commercial aquaculture, resulting in the development of best management practices (FAO 2007). The best management practices provide guidelines for the use of pesticides, feeds and chemicals so that environmental problems can be mitigated or avoided. These best management practices are widely available in the literature, and even government websites, but there needs to be more attention given to the analysis of such materials. The literature is clear that special extension programs exist to disseminate management information, but more critical analysis is needed (CostaPierce 2002). How do these programs spread technical knowledge? Who are they targeting? Do local community members participate in these extension programs? With the development of stricter regulations and more specific guidelines do environmental conflicts still persist? This dissertation answers these questions in the context of Tamil Nadu, India, contributing to important analyses of development governance and networks of knowledge. 


\section{Socio-economic Impacts}

According to development literature, one of the main goals of the Blue Revolution is to improve food security for poor communities. "Food security" is a concept that is nebulous and hard to evaluate. Yet it is a term that continuously arises throughout development literature. In broad terms, it refers to a person's access and ability to meet their most basic food requirements (Cai et al. 2009). I use this definition as my own conceptualization of the term in this dissertation. Some case studies have shown commercial aquaculture to improve local food security through increasing household incomes, which allow families to buy the food that they need. Additionally, food security is improved from the increased protein produced through the aquaculture practice itself (Cai et al. 2009; Pant et al. 2014). Alternatively, other studies conclude that commercial aquaculture, particularly export-oriented shrimp production, impedes food security by blocking other resource users from their modes of subsistence (Ito 2002; Rivera-Ferre 2009). This occurs through changes in land ownership and management (Bhatta and Bhat 1998). Wetlands and coastal zones are usually state owned lands but managed traditionally as a common-pool resource. Although coastal communities use the land, they do not have official land-use rights. The introduction of commercial aquaculture increased the value of coastal zones, which often spurred the states to sell the land to private parties, ignoring traditional claims to the land. This has changed the coastal zones from multiple-use, multiple-user land to privately owned and single-user land (Stonich and Bailey 2000; Ito 2002). This effectively blocks many traditional land users from access to or control of natural resources. For example, Sanae Ito (2002) found that shrimp farming enterprises in Bangladesh create problems in access to clean drinking water. 
Landowners who decided to practice shrimp farming ended up breaking dykes in the river and flooding large areas of land with brackish water, contaminating freshwater sources and salinizing soils. Like Ito's research, this dissertation concludes that the majority of commercial aquaculture practices in Poompuhar, that is, shrimp farming, do not contribute to food security. My research suggests that in fact, shrimp farming as it is currently practiced in Poompuhar restricts household food security due to the fact that cultured shrimp is solely an export commodity that does not contribute to household protein consumption and does not provide improvements to incomes for families in a lower socioeconomic class. However, other local aquaculture practices such as fish farming do hold promise for boosting the availability of protein for local households.

Another important theme in aquaculture studies is its effects on employment. Some scholars argue that in rural communities where job opportunities are limited, commercial aquaculture can provide alternatives. For example, Pant et al. (2014) concluded that aquaculture practices help to diversify local livelihoods and increase household incomes. Additionally, Sanae Ito (2002) found that shrimp farming provided more wage-earning employment opportunities for women through ancillary activities such as snail collection (which is used for feed in aquaculture ponds). However, case studies also demonstrate that the issue of employment is very complex to judge. Although commercial aquaculture may provide job opportunities, it may not improve the quality of living or overall economic conditions in poverty-stricken areas. Barrett et al. (2002) found that the salmon farming industry in Chile was associated with poor working conditions, only seasonal improvements in employment opportunities, and low wages. Additionally, other scholars have found that commercial aquaculture leads to greater 
social stratification in some cases; shrimp farmers prosper, while rice farmers lose income because salinization problems from aquaculture decrease agricultural productivity (Ito 2002; Pradhan and Flaherty 2007; Swapan and Gavin 2010). These factors make it difficult to evaluate the economic impacts that aquaculture activities have on communities, highlighting the need for more case studies that help to contextualize these processes and understand the complexities. This is something that this dissertation addresses, through an analysis of how commercial aquaculture entangles individuals, families, and wider communities in networks of labor, materials, and even risk.

\section{Women in Aquaculture}

There is a growing interest in gender issues within commercial aquaculture practices as well, particularly how women may be affected differently than men by the industry (Ito 2002). Traditionally, women were generally unrecognized in fisheries and aquaculture although they indeed participated. Prior to the 2000s, there was much less scholarly attention to women's activities in the sector and there is a paucity of census data about women's employment in fisheries worldwide. Scholars generally believed that fisheries was a male-dominated sphere in which women did not participate, so most studies focused on collecting statistics about men's activities in aquaculture. One of the reasons that women's roles in aquaculture were ignored is because often their contributions are unpaid (Weeratunge et al. 2010).

Recent women's empowerment programs, part of development strategies, have encouraged the participation of women in commercial aquaculture (FAO 2012). Now their role in aquaculture is much more visible and documented. Women's empowerment 
initiatives seek to improve gender equity by challenging ideologies that support inequalities, by improving women’s access to and control of resources, increasing women's participation in decision making processes, and changing the structures that sustain current power relations (Batliwala 2007; Oxfam 1995; UN 1995). Commercial aquaculture can provide women with employment and helps alleviate food insecurity within the household, which improves the health and status of the whole family (Alauddin and Hamid 1998). Aquaculture has also been promoted as a source of employment for women as part of development strategies because it was assumed that it would be an extension of their domestic tasks. In other words, aquaculture was seen as an appropriate activity for women because it would not take them outside of the private sphere; they could tend fish ponds close to home. However, these assumptions are not necessarily true (Weeratunge et al. 2010).

Feminist scholars reveal that women's participation in commercial aquaculture is much different from that of men. In fact, the commercial aquaculture industry is highly gendered in that there is a strict separation between men and women's involvement in specific activities. Often men participate in the actual on-farm activities, while women participate in the off-farm work, or ancillary activities (Alauddin and Hamid 1998; Ito 2002). Alauddin and Hamid (1998) concluded that shrimp fry collection in particular, is a major source of income for women, especially women who are poor and come from landless rural families. This is because fry collection allows the women to be selfemployed while not having to invest a lot of capital. Other ancillary activities related to aquaculture, such as packaging and processing, are considered more suited for women because they are less physically demanding and are indoors (Interview data 2014). This 
reinforces certain gender ideologies that women are subordinate and less physically capable than men are. However, many questions still exist regarding gender and aquaculture activities. It is not well understood how different aquaculture activities may affect gender relations, or how trends may vary depending on local cultural practices. This dissertation sought to investigate how women are involved in aquaculture practices in Poompuhar, and how such practices may be gendered. This information is important for improving aquaculture extension programs that specifically target women as entrepreneurs.

\section{Contributions to Post-Development Studies}

The term “development” refers to a specific discourse and process that emerged during the post-World War era and that continues into present day. It is characterized by the spread of a Euro-American model of modernity and progress throughout the world and has dramatically restructured social, economic, and political systems in less industrialized and poorer countries (Cullather 2010; McMichael 2012).

A large body of literature, referred to as "post-development” literature, serves to critique the development paradigm itself, and question its strategies and model of progress (Dasgupta 1985; Escobar 1995; Esteva and Prakash; Ferguson 1994; Rahnema and Bawtree 1997; Sachs 1992). These discourses serve as the foundation for this dissertation project. There are many critiques, but two issues in particular guide my research. The first critique is that interventions associated with development strategies follow an exploitative pattern that leads to the subjugation and further impoverishment of target countries/communities (Escobar 1995; Li 2007). This is also one of the causes of 
what economists refer to as the "resource curse" or "paradox of plenty," which refers to the paradox that countries with the most natural resources tend to have less economic growth and a lower overall quality of life (Ross 1999; Sachs and Warner 1995). One of the goals of this dissertation was to investigate the socio-economic impacts of aquaculture development on the local community in order to see if such critiques are appropriate. I found that although aquaculture development programs are not exploitative, on-the-ground aquaculture practices in Poompuhar do contribute to sources of impoverishment for certain community members.

Another prominent post-development critique that guides my research is that many development projects rely on technocratic solutions devised by an ethnocentric "rule of experts" in tackling problems (Escobar 2008; Ferguson 1994; Li 2007; Mitchell 2002). This means that instead of involving community members and integrating traditional knowledge to solve development problems, agencies utilize highly technical science instead. These programs are often planned and managed by people outside the community or from a different socio-economic group than the target communities. These issues are problematic because they can be expensive and time consuming, cancelling out many of the benefits of the programs. There can also be a problem when the people who are planning such programs have a very different perspective and set of priorities than the target communities. One goal of this dissertation was to investigate how aquaculture development practitioners plan and extend new technologies within the community to see if the "rule of experts" applies. I found that indeed, commercial aquaculture development in Tamil Nadu, India is led by technocratic governance that is comparable to a "rule of experts." 
Development interventions are particularly visible in the context of post-disaster reconstruction efforts as well, and post-development scholars have analyzed these engagements. Frederick Cuny (1983), for example, critiqued post-disaster aid for the negative impacts it can have on communities if organizations do not fully understand the needs of the community first. He argued that failures in planning and implementation can actually undermine local coping mechanisms rather than help them, damage local markets, and decrease the community's confidence.

Other scholars are critical of the concepts of vulnerability and resilience that often serve as the measure of success for risk reduction programs and responses to disasters (Adger 2006; Magis 2010). Lewis and Kelman (2010) argue that conceptualizations of both terms need to be contextualized within the specific areas that they are being applied. Additionally, Weichselgartner and Kelman (2015) argue that conceptualizations of resilience need to include structural socio-political processes and should be differentiated from ecological resilience.

Alternatively, Bush and Marschke (2014) argue that conceptualizations of resilience can be usefully synthesized with agrarian change and transition theory. They assert that such a synthesis can help assess the social aspects of transitions in agrarian transitions, particularly transitions to aquaculture systems.

Like these scholars, I believe that with the proper contextualization, the concepts of vulnerability and resilience can be helpful in understanding how communities might overcome economic and environmental changes, and should not be fully abandoned. Additionally, I am critical of the disaster and risk reduction literature. I agree that such literature is not critical of the approaches and effects of post-disaster development and 
that the concepts of vulnerability and resilience do not help us to understand who has the decision-making power when it comes to shaping a community’s ability to recover from disasters and how plans are conceptualized and rationalized. This dissertation builds upon the work of post-development scholars who have critiqued disaster recovery programs by analyzing the results of the post-tsunami programs. However, I combine this analytical lens with the concepts of vulnerability, risk, and resilience in an effort to bridge the gap between the areas of literature. I argue that a synthesis between discourses of risk reduction and post-development can allow us to understand the social implications and impacts of post-disaster recovery in ways that may have been ignored in the past. For example, how recovery efforts may contribute to resilience for some sections of the community and not others or how efforts may lead to class differentiation.

\section{Theoretical Frameworks and Outline of the Dissertation}

The remaining dissertation is organized into five chapters. Chapter 2 is a detailed account of the ethnographic methods used in this research project. I explain the different phases in the study, starting with my pilot research in 2012 and continuing through extended fieldwork in India in 2014. These phases involved a mixed methods approach that utilized archival research, semi-structured interviews, household surveys, and participant observation. In this discussion, I also explain my experience working with a local translator and how my experience affected the research process. I believe that it is an important point to highlight since I conducted research as an “outsider,” not being from the community in which I was working. 
Chapter 3 begins the analytical discussion with the specific historical context of aquaculture development in India. I argue that the commercial aquaculture industry emerged as part of a turn towards investing in development in India and the same initiatives of rural development continue to drive the expansion in contemporary times. Specifically, I highlight the connection between the processes that led to the widespread industrialization of agriculture, otherwise known as the Green Revolution, and the emergence of commercial aquaculture. Other scholars have connected the Green Revolution with the Blue Revolution but I argue that these comparisons often are superficial, and therefore require further elaboration and analysis. In order to address this issue, I compare the Green and Blue Revolutions’ main objectives, implementation strategies, and criticisms.

In Chapter 4, I utilize a post-development theoretical framework to explain the disparity between the goals of aquaculture development programs and actual aquaculture practices in Poompuhar, India. I argue that aquaculture development programs are led by technocratic and science-centric governance that fails to engage with the public. I argue that this type of governance creates an estrangement between researchers, regulators, and aquaculture practitioners. Rather than empowering marginalized groups as aquaculture programs aim, the estrangement creates further problems of environmental and socioeconomic risk. My argument specifically builds upon the work of anthropologists James Ferguson (1994) and Tania Murray Li (2007), both of whom provide an entry point into the critical analysis of development projects. I synthesize their ideas with those of Blaikie et al. (1994), which help explain the social production of risk and vulnerability, a concept that I extend to development programs. 
In chapter 5, I go into an in-depth discussion of the impacts of the 2004 Indian Ocean tsunami on Poompuhar. I explain the various damages to the community and the specific recovery efforts that took place following the disaster. In particular, I highlight a special recovery strategy meant to boost community resilience, that is, alternative livelihood programs. Skill training and extension programs in commercial aquaculture practices were a key part of these alternative livelihood programs. I argue that the use of aquaculture as a post-disaster development strategy allowed for the expansion and intensification of aquaculture development initiatives in India. However, I assert that despite these post-disaster development efforts to diversify local livelihoods, actual livelihood practices are largely unchanged, particularly aquaculture practices. As in the previous chapter, I tie in the work of James Ferguson (1994) and Tania Murray Li (2007) to interrogate how the post-disaster development strategies are a further example of the failures of the "rule of experts."

In chapter 6, I argue that the commercial aquaculture industry in Poompuhar is causing shifts in livelihood structures, comparable to an agrarian transition. Specifically, I describe changes in cash cropping, resource use, and gendered divisions of labor. I use the theoretical framework of the global intimate, as described by geographers Alison Mountz and Jennifer Hyndman (2006), to demonstrate how the "aquaculture transition" entangles with multiscalar networks of materials, knowledge, labor, and risk. These networks act on "intimate" levels such as the home and the body, while simultaneously connecting Poompuhar to global processes. 
In the final chapter, Chapter 7, I conclude the discussion with a summary of my major findings. I also discuss some of the limitations of my research and avenues for further investigation in the future.

\section{Conclusion}

The production of cultured seafood is a rapidly expanding enterprise that promises to become an ever-increasing part of the global food market as we enter into an era of escalating climate change and population growth. In the decades to come, we will rely more and more on intensive and efficient modes of food production but it is imperative that we also balance the impacts of these practices. The early decades of commercial aquaculture have been marred by extensive reports of social, economic, and environmental problems. Clearly, the time has come to increase our scrutiny of such processes in the contexts where they occur and understand how they connect to other legacies and discourses that might be hindering the sustainability of the industry. 


\section{CHAPTER II. RESEARCH SETTING AND METHODS}

In this chapter, I discuss the methods that I followed to collect data for the dissertation research. This chapter has seven main sections. In the first section, I explain the overarching questions that guided the research. The second section describes the research location of Poompuhar, particularly the village's demographics, local economy, and social structure. The third section introduces Poompuhar as a site of rural development, providing a context for further discussions. The fourth section of this chapter details the research phases. I explain the particular ethnographic methods I used, such as semi-structured interviews and household surveys. The fifth section explains my sampling strategies for selecting participants in the household surveys and interviews. The sixth section summarizes some of the demographic data gathered in the household surveys, such as gender ration, age, education, and occupation. Finally, the seventh section is a discussion of working with a translator, particularly how it affected my research process.

\section{Research Questions}

The following overarching questions guided my research:

1) What types of aquaculture practices are taking place within the research site, particularly as part of rural development efforts in the region?

2) What are the underlying ideologies and assumptions that drive aquaculture development in Poompuhar and what are the goals of such development?

3) How is aquaculture transforming social, economic, and environmental realities within Poompuhar? and, 
4) How has the community changed since the tsunami of 2004 and the disaster efforts that followed?

\section{The Research Location}

The research project focused on the village of Poompuhar, located on the South East coast of India, in the Nagapattinam District of the state of Tamil Nadu. Poompuhar is approximately 5-6 hours south (by car) of the State capital, Chennai, and is well connected to surrounding villages and towns by networks of buses, taxis, and autorickshaws. However, the nearest city and train station is 45 minutes away by car, which limits some access to resources and commerce.

Situated on the Bay of Bengal, in the South of India, Poompuhar has a tropical wet-dry climate with average annual rainfall of 50.32 inches. This rainfall is primarily due to the monsoon seasons, both the southwest monsoon and northeast monsoon, which are largely responsible for recharging the state's water resources. Poompuhar's geography is particularly special because the village is located in the Cauvery River delta, a region rich in irrigated agriculture and fishing. The landscape comprises a patchwork of grazing lands (predominately dotted with Prosopis juliflora, an invasive species of thorny shrub that I discuss in a later chapter), paddy fields, small stands of forest, and sandy dunes adjacent to the beach.

Poompuhar is now a humble village, but it is both historically and culturally significant. It was the hub of the ancient Chola kingdom, one of the longest-ruling dynasties of South India, dating back to 300 BCE. Archaeological surveys and ancient texts reveal that Poompuhar was a major trade port, exchanging items from Ancient 
Rome and China. Coins, jewelry, pottery, and other items have been uncovered from these ancient civilizations beneath the coastal waters of Poompuhar. Some of these unearthed items are on display in an archaeological museum within the village. The area is also dotted with the remains of both Buddhist and Hindu temples and shrines from this ancient time. Poompuhar is also the backdrop to the epic love story of Kovalan and Kannagi, one as tragic as Romeo and Juliet and that has inspired many Indian songs and films. The village contains an art museum that displays stone carvings that depict the story. The public beach area also has a monument commemorating the famous lovers. Both the art museum and monument are tourist attractions.

At the local level, the village is governed by a panchayat. A panchayat is a village council, based on traditional self- governing structures common throughout India. The panchayat is comprised of village elders and respected community members, with leadership roles elected by the villagers. The panchayat helps to settle small disputes and address basic village needs, such as constructing bore wells. It also helps to lobby for funding from higher governance structures for bigger projects like improving village sanitation. The area of Poompuhar is actually comprised of two separate village panchayats. One panchayat is Vanagiri and the other is Kaveripoompattinam, but often locals and administrators refer to the whole area as Poompuhar (with variations on the English spelling) based on the historical boundaries of the ancient city. Because these two villages are so intertwined (many people live in one and own a business or work in the other) and spatially close (see Figure 1), I have decided to include both in my study site and refer to it as the village of Poompuhar. 


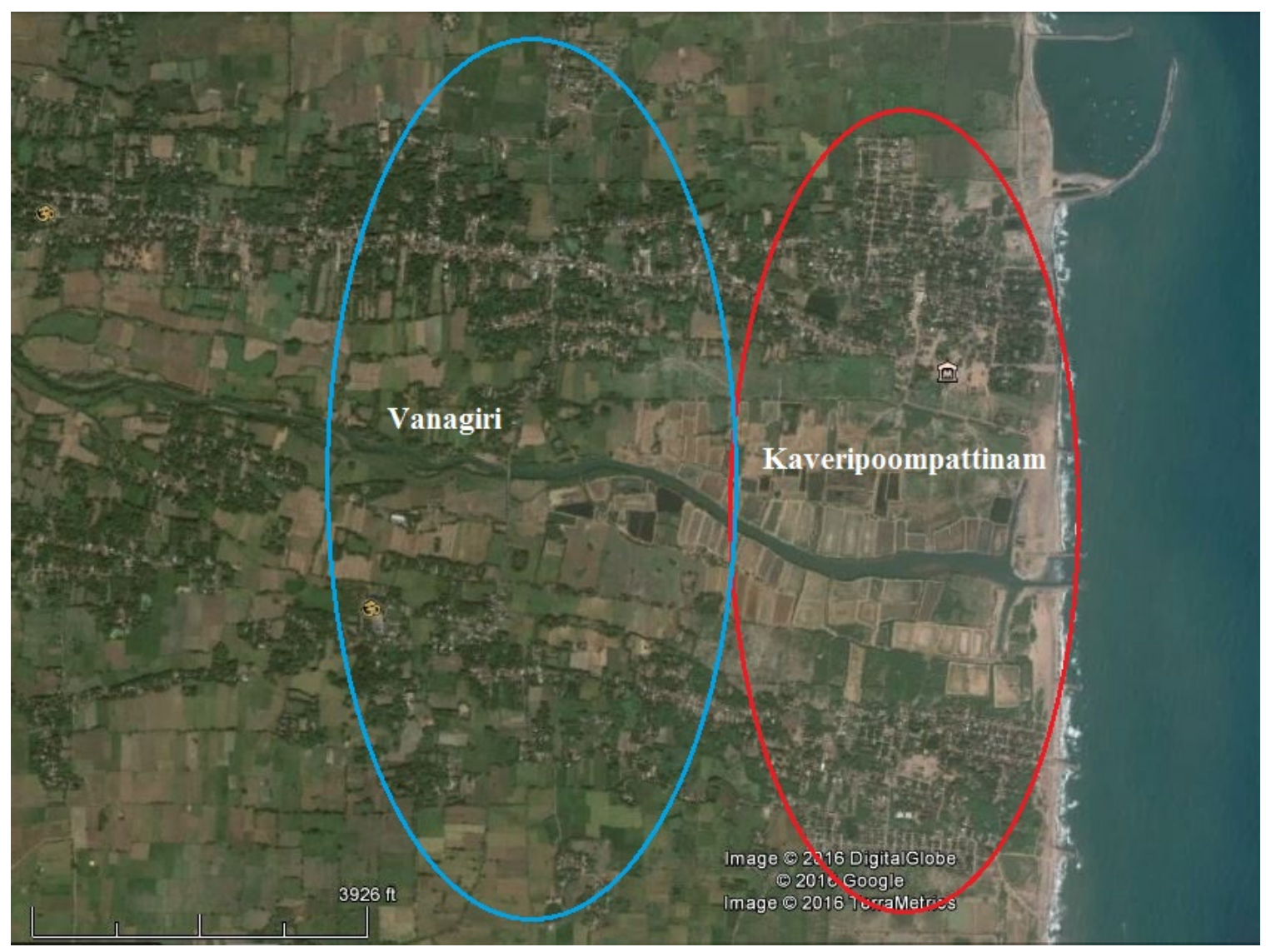

Figure 1. Satellite Image of Poompuhar

The study site extends 3 square miles, and includes homes, shops, agriculture fields, shrimp farms, and the beach. There is a variety of housing types within the village. They range from humble mud-brick and thatched roof homes lacking indoor plumbing, to extensive multi-storied homes that not only have basic amenities, but also what would locally be viewed as luxury items such as air conditioning and indoor toilets. The majority of the population however lives in either the mud-brick and thatched houses or other small concrete structures, with only a few families living in larger structures. Housing type is a visible indicator of socio-economic status within the village, and consequently, I used it to identify local economic and social structures/patterns. It is also 
a significant indicator of the impacts of the 2004 tsunami and which parts of the community received aid. The tsunami destroyed many homes in the village. As part of the recovery efforts, the Indian government, in partnership with NGOs, rebuilt villager's homes. The rebuilt homes are all of the same style, modest size concrete block homes, for a single family, built along straight roads in a grid-like pattern (See Figure 2).

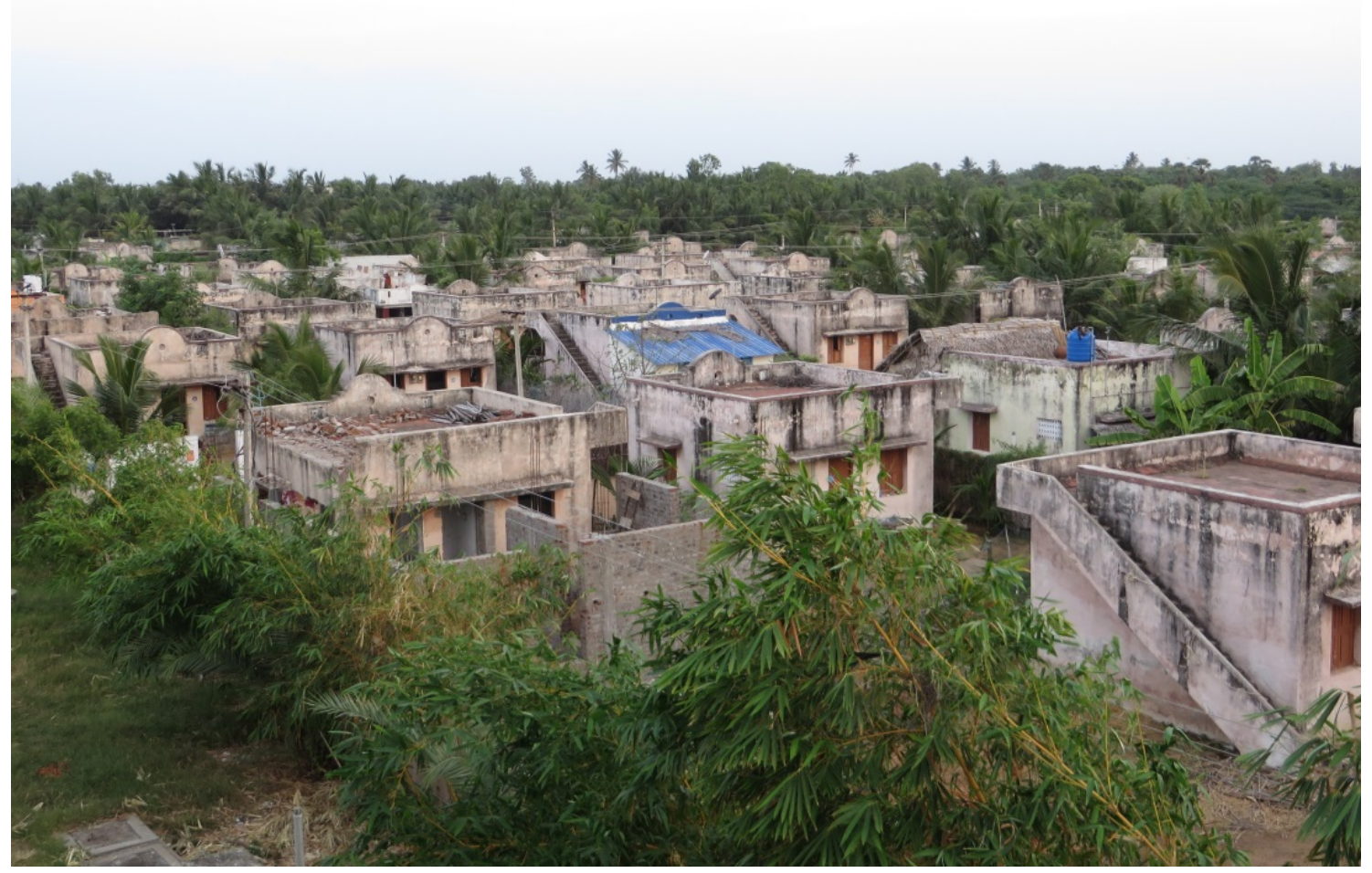

Figure 2. Homes Built After the Tsunami

This type of housing is easy to recognize because it is unlike the traditional style found in the village, which is characterized by a multi-family compound of small dwelling structures surrounded by a fence. Therefore, it is easy to see which families had their homes rebuilt following the tsunami. 
In addition to housing type, several other visual cues and details throughout the village indicate other socio-economic information, particularly livelihood type. For example, within the village there are clusters, or “colonies,” of smaller communities, such as the fishing colony, where most of the fishermen live with their families. Alternatively, there are clusters of farmers. Just by looking at a house, a family's livelihood is often apparent as well. Homes of fisher folk have nets hanging outside to dry or rolled up on the porch. Additionally, homes of fisher folk often have a fish symbol painted on the front of their house or incorporated in the design of their fence or door. Homes of farmers often have livestock kept in the yard such as goats and chickens. There are also clusters of lower caste families, referred to as "SC colonies" or scheduled caste. This categorization pertaining to caste is the official terminology recognized by the government of India. The SC colony in Poompuhar is characterized by lower quality homes, all of mud-brick and thatch. They are also slightly removed from other clusters. These clusters demonstrate the social spatial organization of villager social life, showing that families that are of the same caste often reside near one another.

Census data gathered from the panchayat offices shows that the population of Poompuhar is 24,300; that is 12,000 people in Vanagiri and 12,300 in Kaveripoompattinam. The Vanagiri panchayat secretary estimated that of the 12,000 people in the panchayat, 4,000 are employed with approximately a 50/50 split between agriculture workers and fisher folk. According to the secretary, only a small portion of Vanagiri has a livelihood other than farming or fishing. The panchayat office clerk for Kaveripoompattinam reported that approximately 7,000 people in that panchayat are from fishing households, while 5,000 people are from households where agricultural 
labor is the main source of income. Once again, alternative livelihoods were the minority. However, my own data demonstrated that although households may consider themselves "fishermen" or "farmers," many people actually have a mixed source of income because continuous employment is difficult to find in the village according to my interviews. For example, some families run what is locally referred to as a "petty shop" where they sell convenience items, candy, and snacks. Another under-reported area of employment is women's labor. Although husbands may consider their wife to be a "housewife" who does not have a job, in reality many of those women actually contribute to the household income. Some women may sell the fish that their husbands catch, while others may help pick cotton for a few weeks out of the year.

\section{Land Tenure in Poompuhar}

I define land tenure as the system that determines an individual or organization's property rights; including access, use, control, and associated responsibilities. These rights can be either legally or unofficially granted. The current land tenure in Poompuhar is largely a product of historical institutions during the colonial and post-independence period of India.

During the time of British colonial rule in India (1757-1947), three main types of land tenure systems were established in different areas during different times for taxation and revenue purposes (Banerjee and Iyer 2002). Landlord-based systems, otherwise known as zamindari, gave land tenure to an elite ruling class who were then responsible for collecting revenue in their areas. Individual-based systems, otherwise known as ryotwari, gave land tenure to cultivators who paid their taxes directly to British 
government officers (without the use of a middle-man landlord). Village-based systems, otherwise known as mahalwari, gave land tenure to the village community, which then had the responsibility of collecting and paying taxes. Scholars suggest that these systems were implemented without much understanding of local traditions and rather, were largely based upon the opinions of individual British administrators and various economic theories popular at the time (Banerjee and Iyer 2002). Consequently, the tenure systems were applied in somewhat of an experimental manner and sometimes shifted based on perceived levels of success.

In 1820, the British Governor of the Madras Presidency (an administrative area of South India that included what is presently Tamil Nadu) implemented the ryotwari system, replacing a zamindari system that had been in place for over a decade (Banerjee and Iyer 2002). This eliminated the role Indian landlords had played, granted land title to individual farmers, and gave direct taxing authority to British officers. (Despite the widespread nature of these changes, several districts managed to preserve the zamindari system because they were quite successful in meeting their revenue commitments.) British authorities conducted an extensive land survey that recorded who was cultivating which plots of land and then legal land titles were issued to the cultivators. This meant that the farming caste became the major landowners in the region.

Following India's independence, the area of Madras Presidency, which eventually became Tamil Nadu in 1969, enacted a series of land reform policies. These policies helped protect the rights of land renters, established a land ceiling limiting the size of individually owned plots of land (30 standard acres per family of 5), and redistributed surplus land to marginalized groups such as tribal peoples (Besley and Burgess 2000). 
These historical processes continue to shape land tenure in Poompuhar in contemporary times. As I mentioned, the ryotwari system officially granted property rights to farmers making them the major landowning class, a trend that continues. The majority of landowners I surveyed were from the farming community. These landowners are mainly from the village itself or nearby areas within Tamil Nadu (Interview data 2014). In some cases, these landowners have leased their land out to other local farmers either because they are too old to farm themselves, or as a supplementary income. My interviews revealed that often rent for land leases is paid annually at a fixed amount. These leasing arrangements may involve one tenant or a cooperative tenancy between several farmers. I also observed that property rights and boundaries for privately owned land are only loosely defined in some cases, as uncultivated agricultural land is open for anyone in the village to use as grazing land. These areas are thus treated more as communal land than strictly private.

In addition to private land tenure, there are several other systems within Poompuhar. There is government owned land, otherwise known as "poramboke" land, which makes up a small percentage of the total area. Within the wider Nagapattinam district, poramboke land makes up 83,548 hectares, approximately $3 \%$ of district total area (SNEHA 2009). Several shrimp farmers in Poompuhar actually lease this government owned land. There is also communal land managed by the village that is used for grazing and construction of village infrastructure. Finally, there is land owned by religious groups, mainly as part of the temples scattered throughout the village. 


\section{A Site of Rural Development and Recovery}

As I already discussed, one of the overarching questions of this research is how aquaculture practices are part of rural development programs in the area. However, it is important to highlight the fact that Poompuhar has been, and continues to be the focus of many other rural development programs sponsored by both the State and NGOs. These programs began as early as the 1940s, and such efforts have only intensified following the tsunami in 2004. In this section, I highlight some of the current rural development programs, in order to provide a context for later discussions. In a later chapter, I will discuss the development interventions specific to the tsunami, specifically connecting recovery efforts with the expansion of the aquaculture industry in Poompuhar.

One of the main objectives of rural development programs in India is to alleviate hunger, especially in rural areas. A ration program exists to improve access and affordability of important food items to rural populations. Poompuhar has ration offices that offer basic food amenities to the poorest of villagers at a very low price. Every household may obtain a ration card that makes it eligible to purchase discounted items such as rice, wheat, and kerosene. The amount each household is eligible for is based on the number of people (adults and children) in the household and the total household income (Interview data 2014). For example, a household that is below the poverty line may purchase up to $35 \mathrm{~kg}$ of rice for 1Rs./kg a month (Commissioner Civil Supplies \& Consumer Protection 2009). Members of each household, often women, line up at the office and wait, sometimes for several hours, to receive their rations. The ration program serves to protect households from food scarcity in times of bad harvests and decreases the financial burden of purchasing food, particularly in areas of high unemployment. 
Another social welfare program for rural development is the National Rural Employment Guarantee Act (2005) that addresses the high rates of unemployment, which is a serious problem, particularly in rural areas. Villagers often refer to the program as the “100 day” program, which guarantees work for each household for 100 days a year. Any adult household members may contribute to the 100 days of work. Each day of work pays minimum wage. The provided work is non-skilled manual labor, such as clearing drainage canals, cutting tree branches, or paving roads within the village. This way, villagers receive an income and contribute to better living conditions at the same time. The amount of payment for this work is small, and many villagers complain about its inadequacy. There was also mention from several village members that people take advantage of the 100 days program by collecting payment but not actually working. A village panchayat member told me, "There are some problems with the 100 days work. There is cheating. People get together but no work is done, only talking and trading stories” (Interview data 2014). Evidently, there are issues with this program, but despite its shortcomings, it still has the potential to make a significant difference for families that are below the poverty line.

In addition to these two specific programs, there are other reminders of the occurrence of development interventions throughout Poompuhar. For example, at each panchayat office there are signs detailing the type, number, and cost of various projects completed - serving as a type of monument or proof that progress is taking place. At the Vanagiri office, a sign lists that between 2011 and 2012, 5 drinking water plants were built for a cost of 3.72 lakh rupees, streetlights were built in seven areas for a cost of 4.94 lakh rupees, and 18 roads were paved for a cost of 21.34 lakh rupees. Together, these 
infrastructural improvements cost 30 lakh, approximately \$50,000 US at today’s exchange rate. Additionally, at the Kaveripoompattinam office, a sign explains that between 1998 and 1999 development programs built, $5 \mathrm{~km}$ of roads, a ration store, a school, 2 cremation areas, 1 bridge, 3 public drinking water pumps, 60 toilets, and 20 homes. One hundred and fifty two homes were also connected to electricity in the same period. The total cost of all of these projects was 45,264 lakh rupees, equivalent to approximately $\$ 75,440$ US at today's exchange rate, and came from the central and state

government. These lists reveal that the focus of most of the projects is on providing basic infrastructure such as water, roads, and electricity

The numerous social welfare and development programs occurring in Poompuhar demonstrates that despite its small size, Poompuhar is connected to much wider networks of finance, policy, and politics that continually reshape the social, economic, and environmental reality of the village.

\section{Aquaculture Practices within Poompuhar}

Within the village of Poompuhar, there are two main types of aquaculture practices taking place: freshwater fish farming and shrimp farming.

\section{Freshwater Fish Farming}

Freshwater fish farming in Poompuhar involves the use of man-made earthen ponds several feet deep, ranging in size from approximately 0.5-1.0 hectare in size. The ponds are filled with water from bore wells, which is sometimes supplemented with water from nearby rivers. Ponds are stocked with several varieties of juvenile carp or fry 
sourced from local hatcheries. Specifically, the fish farmers use a composite or polyculture technique that involves common species such as Labeo rohita, Catla Catla, and Cirrhinus mrigala (Interview data 2014). The production cycle requires approximately 8-10 months of growth before the fish are ready for harvest. When harvest time arrives, several local laborers are hired to harvest the fish using dragnets and then the fish are sold in local markets. According to one fish farmer I interviewed, 1 fish weighing $1 \mathrm{~kg}$ (harvestable size) costs Rs. 60 to produce and sells for Rs. 120 at market, resulting in Rs. 60 profit per kg. He reported that in 2014 he produced five metric tonnes of fish, resulting in Rs. 300,000 in profit (approximately US \$5,000).

At the time of my field research, there were three fish farms in operation. One of them consisted of only one pond, another consisted of two ponds, and the third farm consisted of three ponds. Each of the farmers own the land on which their ponds are located, except the farm with three ponds, which includes one pond that is leased from another landowner. Each of the owners of the aquaculture farms used freshwater fish farming as a supplementary income activity, complementing their main livelihood practice. Two of the fish farmers operate chicken farms, and both use chicken waste as manure in their fishponds. The third fish farmer owns land where he farms rice and cotton. He feeds the fish with the rice husks left over from the milling process and supplements with other products from his land such as coconut. The fact that these men had multiple businesses, in addition to owning land, demonstrates that they are from the middle to upper class section of village society. They are also able to use their multiple income earning activities to integrate their production and thereby save money on inputs. 


\section{Shrimp Farming}

Shrimp farming in Poompuhar consists of man-made earthen ponds approximately 3feet deep and 0.5-2.0 hectares in size. The ponds are initially filled with brackish river water using pumps and drainage canals. Once the ponds are full of water, powdered chlorine is mixed in to kill off unwanted bacteria and organisms (Interview data 2014). Then the $\mathrm{pH}$ and salinity are adjusted using bore water and chemical inputs. Once the water quality is set to the appropriate measurements, the ponds are stocked with shrimp seed acquired from local suppliers. At the time of data collection, all of the shrimp farms were stocking the ponds with Litopenaeus vannamei, otherwise known as Pacific white shrimp. The shrimp farmers use pelleted food, comprised of soybean meal, fishmeal, and wheat flour, to feed the shrimp (Interview data 2014). Many of the farms also rely on other technological and chemical inputs such as aerators and probiotics to boost growth rates. The production cycle takes 3-4 months of grow out before the shrimp are at harvestable size. This allows for up to three cycles of shrimp harvests a year.

In 1982, the first shrimp farm began operation in Poompuhar, along the banks of the Cauvery River delta. Before that time, the landscape along the river consisted solely of rice paddies, groundnut fields, and open grazing lands, all divided into privately owned plots. It took over ten years for shrimp farming to catch on in the village, but in the mid1990s, more landowners in the area started to convert their lands to shrimp ponds (Interview data 2014). At the time of my research, 50 shrimp farms were in operation. The average farm consisted of two ponds with four laborers. Most of the shrimp farms had been in operation for more than five years and most were located on private property. 
My interviews revealed that the majority of shrimp farm owners are from the middleupper class of village society, with almost all of them hailing from the agricultural community. Only one shrimp farm owner I interviewed was from the fisher folk community, a section of the village that is generally a lower socio-economic class or a lower caste than people from the agricultural community. That one shrimp farm owner from the fisher folk community however was not poor, and in fact owned a large fishing boat. He also lived in a large house located somewhat apart from the rest of the fisher folk community, signaling that he had moved up in socio-economic class.

\section{Hierarchy of Aquaculture Bureaucracy}

Multiple government ministries and departments regulate and manage various aspects of aquaculture within India (See Figure 3). Figure 3 depicts the organization of the major departments. The Ministry of Environment, Forest and Climate Change and the Coastal Aquaculture Authority under the Department of Animal Husbandry, Dairying, and Fisheries are mainly responsible for creating policy that regulates the aquaculture industry. There are also two main departments that contribute to aquaculture research; those are the Marine Products Export Development Authority and the Department of Agricultural Research and Education. This extensive bureaucratic hierarchy demonstrates the complexity of the aquaculture industry in India, and is one of the reasons that management is difficult.

\section{Research Phases}

I conducted this research in multiple phases in order to address my research questions in the best possible way. Phase I involved "exploratory” field research where I 
visited possible research sites in India and began to develop my research questions. Phase II began two years after phase I, following the development of my research plan. This phase consisted of archival research and interviews with aquaculture research professionals in Chennai, India. The final phase of my research, Phase III, involved the bulk of my ethnographic data collection. Spanning 6 months living in the village of Poompuhar, I conducted household surveys, aquaculture farm surveys, direct observation of aquaculture activities, and semi-structured interviews. 


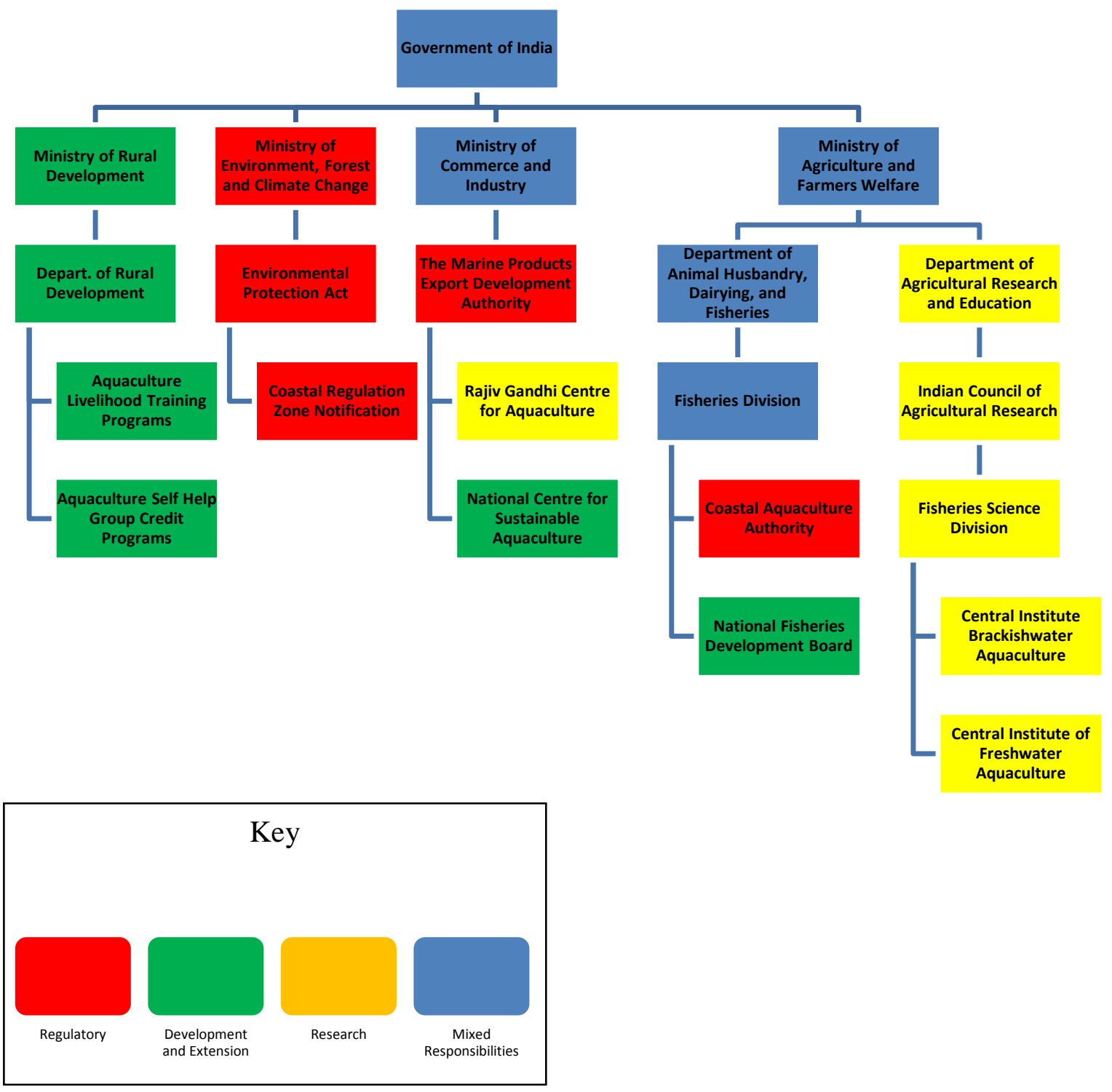

Figure 3. The Bureaucratic Hierarchy of Aquaculture in India 


\section{Phase I - Exploratory Field Research}

This dissertation project began with two months of preliminary field research in South India conducted during the summer of 2012. During this two-month period I worked as an intern at the Dakshin Foundation, a non-profit, non-governmental organization based in Bangalore that works as an advocate for environmental conservation, natural resource management, sustainable livelihoods, and social development. As part of my internship at Dakshin, I gathered information about aquaculture management and policy for the use of the organization's environmental law omnibus website. To do so, I interviewed research staff at the University of Fisheries in Mangalore, and at research stations on the coasts of the Arabian Sea and the Bay of Bengal, where I toured several shrimp and fish farms to observe their practices and interview the farm workers. In addition, I interviewed the director of the Bay of Bengal Programme in Chennai to learn more about his role in the creation of the Aquaculture Authority, the managing body of the aquaculture industry of India. These experiences provided me with a foundation for understanding the structure and management of India's commercial aquaculture industry. They also allowed me to form professional relationships with key stakeholders involved in the aquaculture industry that aided me as I moved on to the next stages of my research project.

\section{Phase II - Chennai, India}

The second phase of my research began in March of 2014, when I arrived in Chennai, India. This phase lasted three months, during which I collected archival data and interviewed several aquaculture researchers and professionals who reside in Chennai. I also completed participant observation at Anna University. 


\section{Participant Observation}

When I arrived in Chennai, I enrolled as an exchange student at Anna University as part of their Institute of Ocean Management program. This affiliation was for visa reasons and because a member of the department, Dr. Ramachandra Bhatta, was serving as my mentor in India. Dr. Bhatta helped me make important contacts in the field and gave me suggestions for my research plan. My affiliation with the department also proved to be a source of data. It allowed me to take part in their $10^{\text {th }}$ annual Indo-Dutch Course on Ecosystem Governance and Services. This program involved topics on various areas in environmental and marine science, such “integrated coastal zone management”, “environmental policy”, and “coastal zone development and disaster management.” Visiting undergraduate students from Amsterdam took part in the program and designed research projects of their own involving environmental and social issues. I sat in on these lectures, participated in the discussions, went on field trips with the Indian and Dutch students and took notes on the subject material presented to the students.

Robin Kearns theorizes that there are three main purposes of observation in social research: counting, complementing, and contextualizing (Kearns 2010). I agree that my purposes were to both complement structured data by providing additional descriptive information and to contextualize by "construct[ing] an in-depth interpretation of a particular time and place through direct experience” (Kearns 2010: 242). My participant observation with the Indo-Dutch course in Chennai allowed me to see how environmental issues, such as climate change, environmental justice, and fisheries management are communicated and taught to students in an Indian University setting. It also demonstrated which topics are primary concerns to the academic community of India and how foreign 
students perceive these issues. Overall, this field experience served as an introduction to the important coastal environmental issues of the region and showed how people are trying to address these issues through academia and research. This data contributed to answering one of my main questions about the ideologies behind aquaculture development, as aquaculture was a part of this lecture series as well. This experience also served as an opportunity to meet important stakeholders who became key informants at a later stage of my research.

\section{Archival Data}

In order to address my questions concerning the ideologies behind aquaculture development, and how such programs are part of rural development initiatives, I wanted to analyze government documents, newspaper articles, and any other materials that might shed light on the topic. I was also interested in exploring how these ideologies may have changed over time. Michael Roche explains that archival research "provide[s] a means of answering questions about the recent as well as the more distant past that are not recoverable by the other techniques” (Roche 2010: 174). I relied on archival materials to provide a historical context as well as access to perspectives that may be difficult to capture through an interview.

I visited the library of the International Collective in Support of Fishworkers, a non-profit organization based in Chennai that works to improve the lives of fishing communities. The organization has an extensive collection of materials about environmental issues, aquaculture, rural development, fisheries, and social activism in India. I searched their bibliography for any materials pertaining to my research questions, and read all the matching materials. I found government documents dating back to the 
1960s and 1970s pertaining to the development of fisheries research in India, legislative records of coastal regulations, annual reports on the progress of government sponsored aquaculture research programs, and news articles about the social activism against the shrimp industry. These documents contributed to my project in several ways. First, I took notes on the history of the aquaculture industry, so that I could better understand how the industry started and expanded in India. I also used the documents to gain an understanding of which government organizations are involved in regulation, management, and research related to aquaculture in India. I also conducted a content analysis of these materials using a coding methodology (Bernard 2011; Cope 2010), specifically coding portions that pertained to: 1) goals of aquaculture programs, 2) aquaculture in relation to the 2004 tsunami, 3) any social, economic, or environmental effects from aquaculture practices, and 4) references to rural development. During the following months of continuing research in India, I also collected pamphlets, leaflets, posters, and other extension/education materials distributed by aquaculture research organizations. I applied the same content analysis to those materials as well.

\section{Semi-structured Interviews}

While I was in Chennai, I conducted three semi-structured interviews with key informants (Bernard 2011). The first interview was with a professor, Dr. A. Shankar, who was involved in the recovery efforts following the 2004 tsunami. She also specializes in coastal risk analysis and disaster mitigation. The information gained from my interview with her helped me to understand how the tsunami recovery efforts were organized and what types of development and aid programs resulted from the disaster. 
My second interview was with the owner of an aquaculture consulting business, Mr. S. Mohan. Mr. Mohan offers training programs for people who want to enter into the aquaculture business. He explained the business side of aquaculture and discussed some of the recent trends in the industry.

The third interview I conducted in Chennai was with the President of an NGO that specializes in aquaculture research and promotion. The President was also involved in the Supreme Court case against shrimp farming in the 1990s. From my interview with him, I learned a lot about the history of aquaculture and some of the current obstacles the industry faces.

I analyzed each one of these interviews using coding methods as previously explained.

\section{Phase III - Poompuhar}

The third phase of this project took place over 6 months of fieldwork in the village of Poompuhar and the wider district of Nagapattinam. During these 6 months, I collected the bulk of the ethnographic data, including aquaculture farm surveys, household surveys, semi-structured interviews and participant observation.

\section{Aquaculture Farm Surveys}

The first thing I did when I arrived in Poompuhar was to survey the area so that I

might become familiar with the region and meet people in the community. I visited 49 aquaculture farms throughout Nagapattinam district. These farms consisted of shrimp farms and freshwater fish farms. I designed a survey instrument that included basic questions about the farms and their operation in order to collect data about the types of aquaculture practices taking place in the region (McGuirk and O’Neill 2010). This data 
served as the context in which I could ground the practices taking place specifically in Poompuhar. I chose to limit the survey to farms within the district, rather than the whole state of Tamil Nadu, because of logistical reasons.

\section{Shrimp Pond Water Quality Measurements}

Within the village of Poompuhar, I took water quality measurements from nine shrimp ponds. The sample size was determined by which shrimp farm owners gave consent. At each sample site, I measured pond water $\mathrm{pH}$, pond water temperature, pond water salinity, and ambient air temperature. Pond water samples were collected using clean glass beakers, first rinsed with distilled water. Water $\mathrm{pH}$ was measured using Litmus paper (Advance Pharma Co. LTD. protocol). Pond water and ambient air temperature were measured using a glass thermometer. Pond water salinity was measured using a Brix refractometer.

\section{Household surveys}

Within the village of Poompuhar, I conducted 77 household surveys using basic methodology of questionnaire design (McGuirk and O’Neill 2010). I designed a survey instrument and first tested it with three households, recording feedback as well as suggestions from my translator. I conducted the surveys in both Tamil and English, depending on the preference of the respondent. For those surveys conducted in Tamil, my translator read the questions in Tamil and translated the responses in English while I was recording. The household survey consisted of basic demographic questions, such as number of people residing in the home, the age, and education level of each household member. There were also several questions concerning involvement in shrimp farming, and changes to the community after the tsunami (see appendix 1). Often the household 
surveys led to more in depth interviews that continued following the survey. The data gathered from the surveys allowed me to gain an understanding of the basic social structure of the village and allowed me to meet many people with whom I could interview for more in depth information regarding the research topic.

\section{Semi-Structured Interviews}

I conducted 40 semi-structured interviews with various members of the community and the surrounding region such as farmers, fishermen, women in a Self Help Group, government workers, researchers, and NGO workers. I tailored the interview questions to fit the specific person with whom I was speaking. For example, when speaking with an NGO worker, I asked questions about their organization and how it contributes to the community. I conducted interviews until I reached saturation with my research questions (Corbin and Strauss 2008). These interviews were recorded and analyzed using the coding system already discussed.

\section{Participant Observation and Field Observation}

I employed two types of observation techniques during the research phase in Poompuhar. The first type is participant observation (Kearns 2010). I took part in daily activities in the village, such as religious ceremonies, birthday celebrations, and family dinners. During these events, I observed the social interactions of the village members and later took notes on the information I gained concerning the local economy, household dynamics, and gender relations. Taking part in these activities allowed me to achieve a better rapport with the community and meet people with whom I could interview. Actually participating in community life gave me a better understanding of daily life, rather than merely reading about it or observing it in a detached manner. 
During my fieldwork, one of my goals was to take part in some aquaculture training programs that are often run by the local research institutes, M.S. Swaminathan Fish for All Centre or the Rajiv Gandhi Centre for Aquaculture. Unfortunately, despite my many attempts, my participation could not be arranged. The program leaders always failed to notify me when the program was taking place, and then later explained it was due to poor planning or short notice. I got the feeling that my participation was either unwanted, or my desire to participate was not taken seriously. Either way, I unfortunately did not get to observe any of the training exercises with the community. Even so, the experience of being "put off" gave me some significant data in itself.

I also conducted another type of observation, one that I term "field observation," which is just purely observational without the participation aspect. In some cases, it was impossible for me to take part in activities, such as harvesting shrimp, because of safety concerns or social customs (for example, women are not allowed to harvest shrimp because it is very labor intensive). In those cases, I observed the activities and took notes on what I saw. This form of data collection was very productive. I used it many times when I visited aquaculture farms, fish markets, and seafood processing facilities.

\section{Sampling Strategy}

In this section, I discuss the sampling strategies used for this research as well as recruitment, and maintaining anonymity. For aquaculture farm surveys, I employed a Convenience Sample, otherwise known as an “availability” sample (Babbie 1998; Mutchnick and Berg 1995). This type of sampling strategy relies on people who are readily available to the researcher. A Convenience Sample was appropriate in this 
situation because the population was unknown, making random sampling impossible. I focused on recruiting people who worked on or owned aquaculture farms, but the number of people in this population is unknown both in census data and in other demographic records. Consequently, I relied on word of mouth and the knowledge of my translator to locate aquaculture farms and then I surveyed whomever was present and willing to participate. I surveyed as many aquaculture farms as I possibly could in the Nagapattinam district, resulting in 49 surveys, therefore my sample size was based on availability rather than a pre-determined number.

The purpose of the household surveys was to gain a better understanding of the dynamics of the community and to expand my network of interviewees. I did not plan to apply statistical analysis to the data from the household surveys; therefore, a nonprobability sampling strategy was appropriate (McGuirk and O’Neill 2010). I utilized both snowball sampling and purposive sampling. I wanted to recruit participants from different sections of the community, and I used livelihood strategy as the parameter since that is the way households organize themselves within the village. I visited different colonies within the village (fishing and agriculture) and then selected households based on availability. In order to target people from other livelihood strategies I visited different places of work around the village, such as tea stalls, tailor shops, taxi stands, and the bank, and then conducted the survey with people who were willing to participate. I also found it more feasible to conduct the surveys with people at their places of work because that was when they were available during the day. It was safer and more appropriate for me, as a foreign woman, to conduct my research during the day, rather than traveling around the village at night. Other participants became involved through word of mouth, 
as they saw I was speaking with their neighbor and they wanted to participate, so in those circumstances a snowball sampling strategy applies.

For the semi-structured interviews, I used three sampling strategies: a) purposive sampling, b) theoretical sampling, and c) snowball sampling (Corbin and Strauss 2008; McGuirk and O’Neill 2010). When I first designed my research plan for my data collection in Poompuhar there were a few people that I knew I wanted to interview based on my previous visit to India. I purposely selected these people because I knew they had knowledge about my research topic. As I conducted the household surveys and met more people in the community, I received suggestions about other people I should interview. When appropriate, I followed through with this advice and my sample size grew based on the "snowball” effect. My research was an iterative process, sensitive to emerging theories and avenues of investigation as I learned more about the community. When I first arrived in Poompuhar, my focus was more on the relation of aquaculture to postdisaster recovery, but as I learned more, I realized that aquaculture practices are embedded in much longer legacies of rural development that I needed to explore. Consequently, part of my interview sample developed through theoretical sampling, allowing me to pursue different ideas rather than focusing on testing one hypothesis (Corbin and Strauss 2008).

The names of the places and research settings are unchanged in this dissertation, but I refer to my interviewees and participants by pseudonyms in order to protect their anonymity. In some cases, I have also changed people’s identifying details so that they remain anonymous. Although I worked with a translator, all research documents and 
materials are in my possession, in a secure, locked location. I also trained my translator to follow proper ethical guidelines and protect the identity of informants.

\section{Demographic Overview of Household Surveys}

I conducted 77 household surveys, which accounted for 379 total residents (approximately 1.6\% of the total population of Poompuhar). The following information is a summary of the demographic data I collected which describes the survey sample, but is not representative of the total population due to sampling techniques (as previously discussed).

Of these residents surveyed, 196 (52\%) are men and 183 (48\%) are women. The average household size is five members. The ages of residents ranged from less than a year, to 80 years old. The average age of the sample of residents is 31 years. Of the 77 households, 27 own land (other than the plot on which their house resides), or approximately $35 \%$ of the sample.

\section{Education}

Of the 77 households surveyed, I was able to record the highest level of education completed for 279 adults. In the context of education, I define an adult as someone 14 years of age or older. This is because it is compulsory for students to attend

school in India up to the age of 14 (usually equivalent to $8^{\text {th }}$ standard/grade). Despite this law however, 38 people surveyed (14\%) reported to have no formal education, with over two times more women uneducated than men. Additionally, 31\% of adults surveyed completed less than an $8^{\text {th }}$ standard/grade education. 
The gender gap closes significantly among college-educated residents, as 33 men and 31 women reported having at least some college education - almost equal amounts. In fact, the only person to have a doctoral degree in the sample is a woman. However, twice as many men than women hold a degree higher than a bachelor's (a master's degree). The most common degree is a Bachelor's in Commerce. Overall, the number of sample adults to have some college education accounts for $23 \%$ of the sample that reported education, while $23 \%$ have only a secondary education (up to $10^{\text {th }}$ standard/grade), and $9 \%$ have only a higher secondary education (up to $12^{\text {th }}$ standard/grade).

\section{Occupation}

Of the 379 residents accounted for in the household surveys, 160 reported their occupation status (see Table 1). The most common occupation reported was "fisherman," and when combined with other capture fishery related activities (selling fish or fish products practiced by the wives of fishermen) it accounted for $24 \%$ of those who reported their occupation. The second most common occupation was "farmer," accounting for $12 \%$ of those who reported their occupation. Twelve people reported that they were unemployed and looking for a job. Thirteen people reported that they owned shrimp farms (accounted for separately from fisherman or farmer). 


\begin{tabular}{|l|l|}
\hline Occupation & Number of People \\
\hline Fisherman & 26 \\
\hline Farm owner & 19 \\
\hline Laborer & 18 \\
\hline Fish seller/pickle & 13 \\
\hline Shrimp farm owner & 13 \\
\hline Unemployed & 12 \\
\hline Housewife & 8 \\
\hline Shop owner & 8 \\
\hline Civil engineer & 7 \\
\hline Business person & 5 \\
\hline Teacher & 5 \\
\hline Shop worker & 5 \\
\hline Bismi (aquaculture product) dealer & 4 \\
\hline Banker & 3 \\
\hline Tailor & 3 \\
\hline Panchayat leader & 2 \\
\hline Retired & 2 \\
\hline Astrologer & 1 \\
\hline Brickmaker & 1 \\
\hline Driver & 1 \\
\hline Mechanic & 1 \\
\hline Dentist & 1 \\
\hline Goat herder & 1 \\
\hline Nurse & 1 \\
\hline Total & 160 \\
\hline
\end{tabular}

Table 1. A list of reported occupations from the household survey with the number of people represented for each.

\section{Working with a Translator}

The official language of Tamil Nadu is Tamil, meaning that the majority of the population speaks Tamil as its primary language. I received Tamil lessons prior to arriving in India, as well as during my fieldwork in Chennai, however, I still found it necessary to hire a translator to help me with my research. There were several reasons I found a translator necessary. The first reason is that despite my lessons I am not fluent in 
Tamil, therefore to converse with someone who only speaks Tamil, I needed help. There is also a regional difference in dialect in rural areas, so I found it best to hire a translator that would be familiar with the way that village people in my research site talked. Another reason I wanted to hire a translator, was so that he or she could help me establish rapport with the local community.

When selecting a translator or research assistant there are many issues to consider, such as gender, age, socio-economic class, education, local knowledge and experience. Just as the standpoint of the researcher introduces certain biases to the project and affects the outcome, so does the translator or research assistant (Sayer 1992). There are also limiting factors such as funding, availability of translators, and other logistics. Ideally, I wanted to hire a person from the village, so that they would have local knowledge and would be in the best position to help me establish rapport with the community. I also wanted someone who could read and write English and Tamil as well as speak it. This meant that I was most likely in need of someone with a higher education. I also struggled with issue of gender, as gender relations can be an obstacle in ethnographic work (Warren and Hackney 2000). Being a woman, I worried that I might not have access to certain informants as most of the aquaculture professionals are men and they may not feel comfortable speaking with me. I also worried that my credibility would be affected because I am a woman researching a topic that is largely male-dominated. Because of these factors, I thought that a male translator might aid in overcoming these obstacles. On the other hand, anthropologists have reported that being male can restrict access to female informants, particularly household data, so I worried that a male translator could make some of my female interviewees uncomfortable. Ultimately, I found that although 
these considerations are important, selection primarily depends upon availability. Consequently, because few people living in the village had the qualifications for which I was looking, the possible candidates were limited.

I selected M. Vasanthakumar, who is native to the village of Poompuhar. His family grows rice and cotton on a few acres of land that they own adjacent to the shrimp farms in the area. The director of the M.S. Swaminathan Fish for All Centre recommended him to me because Vasanthakumar has education and work experience in environmental studies. He also knows many people in the village and is familiar with the aquaculture farms in the region. His local knowledge, combined with his work experience was a huge asset to my project because he was able to serve as a guide. In addition to translating interviews from Tamil to English, he also introduced me to many key stakeholders. He also helped me navigate the social customs of the village, with which I was not fully accustomed. Ultimately, Vasanthakumar became much more than a translator; he was a research assistant, guide and friend.

As I explained, the standpoint of the translator affects the research just as much as the researcher and it is important to identify the possible biases. I realized that because Vasanthakumar was from the farming community, he felt more comfortable speaking with farmers rather than fishermen, so he was more likely to introduce me to members of his own community. I had to overcome this by reminding him that I needed to speak with a variety of people from the community. Another obstacle was that because he is an unmarried man, he felt uncomfortable speaking with groups of women, especially if they were complaining about their husbands. I have to acknowledge the fact that in some cases like this, some comments from the interviewees might have been lost in the translation 
process. Ideally, I would have liked to use multiple translators, or perhaps someone who was specifically trained as a translator (which Vasanthakumar was not) but my budget and access to such people was limited. In working with Vasanthakumar, I realized that he was like a filter in the research process; some details were lost in his translation, while others easily emerged. This constraint occurs in any project that is reliant on a translator. However, I am reassured in knowing that whatever details I lost with a translator, I gained much more in having the assistance of someone with an intimate knowledge of the community with which I was working. I also believe that his familiarity with the area, combined with my "outsider” perspective created a successful combination that allowed for critical analysis.

\section{Conclusion}

This dissertation project serves as a case study of commercial aquaculture livelihood practices in Poompuhar, India, but it has broader applications for understanding processes of rural development, agrarian change, post-disaster recovery, and globalization in other locations. For example, my research suggests that the way in which aquaculture development discourses and approaches are applied within Poompuhar may be indicative of countrywide trends throughout India. The reason is that the aquaculture research and extension institutes that are active in Poompuhar are part of a larger network of government-funded institutes scattered throughout the country. Most fall under the jurisdiction of the same government department, the Department of Agriculture Research and Education, which means that they all have the same mission and objectives. 
My research findings concerning the socio-economic and environmental impacts of the commercial aquaculture industry, as well as the process of agrarian change in Poompuhar may also be applicable to other rural areas in developing countries, particularly areas with similar socio-economic structures. This is because many of these impacts coincide with the findings of other research studies. This suggests that the commercial aquaculture industry, particularly shrimp farming (which dominates my analyses), has similar impacts across regions.

The way in which aquaculture has been incorporated into post-disaster development techniques in Poompuhar may also be indicative of post-disaster experiences in other places around the world, particularly where alternative livelihood schemes have been introduced. My interviews with NGO workers in India revealed that alternative livelihood programs are a common approach for development professionals seeking to increase community resilience. Consequently, I believe that some of the outcomes experienced in Poompuhar may be similar to those in other areas. This also means that development workers can learn from the experiences of Poompuhar and use that information to improve future programs.

I also believe my research is representative of many other rural areas entangled in similar processes of industrialized food production, particularly situations where food production livelihoods are promoted within programs of rural development. Ultimately, the findings of my research helps scholars understand some of the impacts of globalization. 


\section{CHAPTER III. ALIGNMENTS BETWEEN THE GREEN REVOLUTION, BLUE REVOLUTION, AND THE DEVELOPMENT PROJECT}

There is an assumption in the literature that the industrialization and expansion of aquaculture is a clear solution to most rural development goals. Numerous scholars have explored the impacts that aquaculture has on rural communities. Nearly all of these studies, however, focus almost exclusively on levels of economic stimulation and food security, showing that aquaculture is seen first and foremost as a form of rural development. For example, Bouis found that fish aquaculture contributes between 5 and $10 \%$ of total household incomes in rural communities in Bangladesh (Bouis 2000).

Additionally, Pradhan and Flaherty (2007) investigated how shrimp farming affects local employment in coastal villages in Orissa, India.

While these studies seek to answer important questions regarding the impacts of the commercial aquaculture industry, there is a need for more analysis regarding how aquaculture fits into broader processes and discourses of rural development. Scholars refer to the rise of commercial aquaculture as the "Blue Revolution," highlighting the similarities between the industry and the industrialized agricultural practices of the Green Revolution (Islam 2014; Stonich and Bailey 2000). However, there has been much greater critical examination of the social processes associated with the Green Revolution than with the Blue Revolution. Furthermore, many of the contrasts between the two revolutions end in a superficial discussion, without fully explaining the importance and impact of the legacy of the post-World War II development turn. I argue that the commercial aquaculture industry emerged as part of a broader turn towards investing in 
development in India that involved the Green Revolution as well, and that the same initiatives of rural development continue to drive aquaculture expansion in contemporary times.

The chapter has five main sections. In the first section, I explain the historical and ideological underpinnings that serve as the foundation of both the Green and Blue Revolutions. In the second section, I delve deeper into the development objective of food security, highlighting the various perspectives concerning each Revolution. In the third section, I discuss some of the main criticisms of the Revolutions regarding environmental impacts. In the fourth section, I discuss how the technocratic implementation of both Revolutions has raised criticism from scholars. Lastly, in the fifth section I highlight perspectives on the gendered impacts of both Revolutions.

\section{Historical and Ideological Underpinnings of the Green Revolution and Blue Revolution in India}

The Development Project and the Green Revolution

Following World War II, American and European governments were increasingly concerned with regions of poverty and civil unrest (Cullather 2010). Political leaders were afraid that the unstable conditions would lead to peasant uprisings, communist expansion, and ultimately a challenge to Western leadership. Cullather explains, "The image of the Asian peasant, shaking off his ancestral torpor and taking up modern arms, aroused primal fears. As early as 1900, theorists warned that the peasant problem might ultimately defeat any global order the United States might try to construct" (Cullather 2010: 2-3). 
As a solution, Western governments began a series of techno-political interventions in less industrialized and poorer countries (particularly in Asia) in order to improve human quality of life, political stability, and economic growth. These interventions also served as a way for the United States and its allies to gain geopolitical power in the developing world while remaking it in its own image. This is what scholars, such as Philip McMichael, refer to as the "development project” (McMichael 2012). The development project consisted of structural adjustment policies, transfers of technology, and trade liberalization (McMichael 2012). When I use the term "developing countries,” I am referring to the less industrialized countries that were the target of the development project.

One of the main development strategies starting in the 1940s was addressing hunger in developing countries. Planners believed that if communities could overcome hunger, they would be more stable and productive (Cullather 2010). Additionally, Cullather explains that, "By asserting control over agriculture, nations defeated their internal enemies and gained a degree of authority over resources, territory, and people that colonial empires never had” (Cullather 2010: 7). In other words, improved agricultural techniques allowed the West to gain power over countries in a new way. In order to increase food production, scientists such as Norman Borlaug applied modern technologies to agriculture. Through genetic improvement techniques, researchers developed new seed varieties, dubbed "miracle seeds" that had higher yields and faster growth rates (Glaeser 1987). These techniques were first applied to wheat, but improvements to corn and rice varieties soon followed. However, these new seeds were 
not the only changes in agriculture. The whole agricultural process was industrialized. Small subsistence farms were replaced by huge operations farming a single crop requiring many inputs of fertilizers and pesticides (Flaherty et al. 2009; Glaeser 1987). The World Bank, the U.S. Government, The Rockefeller Foundation, and the Ford Foundation primarily funded these processes (Cullather 2010; Glaeser 1987). Countries were able to produce more food for local consumption as well as export the surpluses in the global market. This heralded a new age of human control over nature and the end to many traditional subsistence practices (Shiva 1991). Scholars refer to this rural development process as the “Green Revolution.” They consider it a “revolution” because its political and technological achievements were unprecedented in human history (Shiva 1991). It also dramatically changed the lives of millions of people, particularly in Asia, and has lasting effects even today.

India was one of the main sites of the Green Revolution mainly due to two processes that took place in the decades following World War II: food shortages and modernization. From 1964-1966, India suffered successive droughts causing food shortages. With a growing population, the issue of food security became an everincreasing concern. India was also a newly independent nation at this time (gaining independence in 1947) and politicians grappled with different models of progress and modernity. Many Indians felt as though India was not at its full potential because British colonial occupation had exploited and restricted Indian society. Two main political factions emerged with different ideas of development, one being the Gandhian model that pushed for a revival of rural village communities, the other being the Nehruvian model 
that embraced Western capitalism and industrialization (Baviskar 1995; Gadgil and Guha 1993). Eventually the Nehruvian model, named for India’s first Prime Minister Jawaharlal Nehru, “won” and India’s national policies supported industrialization and investments in modern technology (Baviskar 1995). The modernization of agriculture with chemical, irrigation and seed technologies addressed the problem of food production while at the same time fitting in to India’s economic plans, consequently, the Green Revolution gained support in India.

In 1966, following a partnership between Norman Borlaug and Indian agricultural scientist M. S. Swaminathan, Indian farmers started to adopt high yield varieties (HYVs) of grain crops. Borlaug and Swaminathan introduced five different HYV grains: wheat, rice, maize, sorghum, and pearl millet (bajra in Hindi). Agricultural scientists designed the HYV of each crop to respond well to fertilizers, have higher yields than indigenous varieties, withstand drought, and grow faster to allow for multiple harvests in a year (Chakravarti 1973). Initially, this new technology was mainly applied in North India, in the states of Punjab, Haryana, and Uttar Pradesh, because there was pre-existing irrigation networks (Whitcombe 1972). The availability of irrigation was essential to the success of HYVs because scientists found that $70 \%$ of India did not receive enough or consistent enough rainfall to support HYVs (Chakravarti 1973). The new technology spread throughout India through the "Intensive Agricultural District Programme” (IADP), a government program that involved demonstration farms, credit schemes, and the dispersal of seeds, fertilizers, and pesticides (Chakravarti 1973). Since the late 1960s, HYV crops have spread throughout India but the North, frequently referred to as India's 
"bread basket” for its high wheat production, still has the highest concentrations of HYV farms.

\section{The Blue Revolution}

The farming of fish, shrimp, and other aquatic life has a long history in India, particularly in coastal areas (Interview data 2014). For centuries, people carried out such practices on a small scale with little or no inputs. Aquaculture professionals refer to these early practices as "traditional” aquaculture methods, taking place before modern refrigeration, mechanization of equipment, or the introduction of chemicals to the farming process (Interview data 2014). The types of practices carried out varied by region, depending on the natural resources available and fish species preferred. In Kerala, farmers practiced integrated paddy-cum-shrimp farming, trapping wild stocks of juvenile shrimp in pokkali fields, a type of rice resistant to high salinities. In West Bengal, farmers used bheries, manmade ponds, to trap juvenile fish in the brackish wetland areas. These ponds relied on natural water exchange through tidal or riverine action and did not dramatically alter the surrounding environment (Interview data 2014). Once the shrimp or fish grew to marketable size, farmers harvested them, used them for personal subsistence or dried the fish and shipped them to East Asia (Vivekanandan and Kurien 1997). Traditional aquaculture did not significantly contribute to the national economy, and in some locations, these practices continue, however not in the study site of Poompuhar.

Traditional aquaculture practices remained largely unchanged in India until the progress of the Green Revolution opened the door for further changes in food production in the 1970s, establishing a precedent for industrialization and intensification. As a result, 
the Central Government of India sought to transfer the approaches of the Green Revolution to modernize agriculture to the production of fish, to further boost food production and stimulate local economies. Aquaculture research and fisheries studies became a main goal of the Ministry of Agriculture and Irrigation, with funding from the government. The fact that commercial aquaculture fell under the management of the Ministry of Agriculture and Irrigation, the same government department that facilitated the Green Revolution, is an important point to highlight. It demonstrates that aquaculture has always been perceived and regulated primarily as an agricultural activity in India, sharing the same goals and style of development. This trend continues into present day, as the main governing body over the aquaculture industry in India is part of the Ministry of Agriculture and Farmers Welfare.

As part of the government's initiatives, fishery scientists, notably Dr. Modadugu Gupta, developed scientific methods of breeding and stocking fish and advised on intensifying fish farming efforts. Freshwater fish such as Indian carp species were the first targets (Ministry of Agriculture 1973). Scientists recommended using machines, such as aerators and water pumps, to allow for higher pond stocking densities. Fish farmers also began to use probiotics and chemicals to control water quality and increase fish growth.

There are significant similarities between the Green Revolution and the changes to aquaculture, which I will discuss more of in further sections. However, because of these similarities, scholars refer to the changes that took place within the aquaculture industry as the "Blue Revolution" (Stonich and Bailey 2000). The use of the term now 
signifies a specific type of aquaculture, one that is industrialized, modernized, and commercialized.

My archival research at the International Collective in Support of Fishworkers (ICSF) library in Chennai revealed the importance of government sponsored research institutes in the creation of the Blue Revolution in India. The Central Inland Fisheries Research Institute (CIFRI) under the Indian Council of Agricultural Research was founded in 1959, the first of its kind in India. According to archival documents, CIFRI's initial goals were to survey the country's inland fisheries resources, understand fishery ecology, and determine the best utilization of fisheries resources. An annual report in 1976 from the Ministry of Agriculture and Irrigation documents how these objectives expanded during the 1970s to include the potential of aquaculture. In 1971, CIFRI initiated the All India Coordinated Research Project (AICRP) on Composite Culture of Indian and Exotic Fishes (Ministry of Agriculture and Irrigation 1976). The project successfully produced high yields of cultured carp and in the following three years, several other AICRPs initiated. The AICRPs established scientific methods for culturing fish and introduced technologies for culturing fish on a large scale. By 1973, there were fish farm training programs, seed farms distributing juvenile fish to other farms, and plans to set up fish farmer development agencies (Ministry of Agriculture 1973). The majority of aquaculture activities at this time were in Assam, West Bengal, Bihar and Orissa due to their abundant freshwater resources. From my archival research, I discovered that the objectives of these projects were threefold, as described in the Fisheries five-year plan of 1973: 
To increase the availability of protein-rich food thereby contributing towards bridging the protein gap in the Indian diet. To improve the socioeconomic conditions of fishermen who are among the economically weaker sections of the population through measures designed to provide more effective and remunerative methods of production and distribution. To tap on an increasing scale the vast potential for foreign exchange earnings through export of selected high priced varieties (Ministry of Agriculture 1973).

This quote highlights how the Indian Government envisioned aquaculture as a solution to food security problems and poverty, aligning it with economic and social development from the very beginning. These were also the same objectives of the Green Revolution. However, this quote also identifies a key divergence between the Green and Blue Revolutions, which is that aquaculture was not only developed as a source of domestic food production, like in the Green Revolution, but also as an export commodity. This is most apparent in the shrimp farming industry, one of the largest aquaculture sectors in India and a leader in export production.

It is also important to underscore the point that fishing communities were the target community for aquaculture development programs rather than farmers, another difference between the Green and Blue Revolutions, and a fact that continues to this day. The quote explains that the reason fishermen are specific targets is because they are one of the most impoverished groups in India, but based on my interviews with aquaculture extension workers I believe there is an additional reason. This reason is that aquaculture seems like a perfect fit for people who already have knowledge about aquatic systems and fish, as well as people who are also already living in coastal areas where aquaculture is most viable. My interviews with aquaculture extension professionals revealed that most of the programs to teach community members about aquaculture target fishermen or the 
women of fishing communities. However, when I surveyed the current aquaculture farms in Nagapattinam district, most of the farm owners and laborers were from the agriculture community - not fisher folk. This is because aquaculture generally requires land for ponds or tanks in which to farm the fish. Agriculture communities in India traditionally own more land than fishing communities, therefore making it much easier for members of the agriculture community to transition to aquaculture than it is for fisher folk. There is also a dramatic livelihood difference between fishing and aquaculture, whereas aquaculture and farming are more similar because they require similar techniques. Dr. Jahan, an aquaculture extension worker I interviewed at the Central Marine Fisheries Research Institute, agreed with this problem. He said, “It’s hard to bring a hunter back to sitting and waiting; they feel a loss of independence” (Interview data 2014). This issue is just one example of the discrepancies between the objectives of state-sponsored aquaculture development and the realities of the industry in India, a topic that I discuss in further detail in another chapter.

My archival analysis showed that the successful development of aquaculture technology and practices through the AICRPs proved to the Central Government that aquaculture could be a viable development strategy (Ministry of Agriculture and Irrigation 1976). This led to the further expansion of aquaculture research in India and the establishment of several other important government research institutes, such as the Central Marine Fisheries Research Institute (1973), the Central Institute of Brackishwater Aquaculture (1987), and the Central Institute of Freshwater Aquaculture (1987). All of these institutes are part of the Indian Council of Agricultural Research (ICAR). Each 
institute has many regional offices, field stations, and experimental farms, creating a large network of aquaculture research and development throughout India. In addition, ICAR in partnership with state governments also sponsors a number of fisheries and aquaculture related colleges and universities throughout India. These colleges and universities train students to enter the aquaculture industry, either as regulators, extension workers, or even aquaculture business owners.

Another major boost to modern aquaculture in India was the establishment of an aquaculture division under the Marine Products and Export Development Authority (MPEDA) in 1979, part of the Ministry of Commerce and Industry (Interview data 2014). This signaled the beginning of cultured marine products as a major export commodity in India. It also introduced a categorization system for shrimp farming based on farm size and stocking density, which has become an important factor in contemporary aquaculture management.

The aquaculture industry in India experienced a significant period of growth in the 1990s when shrimp farming became an intensive practice (Kurien 1997). This period, otherwise known as the "shrimp boom," was a product of several economic forces on both the domestic and global scale, both once again tied to development initiatives. However, as I will discuss, the shrimp boom also marks another important point in the divergence between the Green and Blue Revolutions, as it entangles the commercial aquaculture industry of India with contemporary processes of globalization and neoliberalism. 
In 1991, the Government of India spearheaded by then Prime Minister Narasimha Rao introduced economic liberalization policies to encourage economic growth and foreign exchange. These economic changes, which included privatization and trade incentives, were in response to a currency crisis and large amounts of debt owed to international aid agencies. The overall goal was to open the Indian economy to global markets and make India one of the fastest developing countries in the world. One of the industries encouraged at this time was shrimp farming (Kurien 1997). The foreign exchange value for shrimp was high, yet wild captured shrimp was in decline in India. This created an opportunity to invest in shrimp farming, which was already successful in other developing countries such as China. There was also a market gap to fill because the demand from the U.S.A, Japan, and UK was high, yet the Taiwanese market that had dominated through the 1980s had collapsed in 1988 due to shrimp disease outbreaks (Kurien 1997). International aid organizations were also key catalysts to the aquaculture boom in India, as they encouraged trade liberalization with funded investment programs in Indian agriculture and fisheries. For example, in 1992, the World Bank gave US\$ 1.7 billion to India for the development of aquaculture, most of which was used for the expansion of shrimp aquaculture (Mukherjee 1994).

Farmers soon found that they could get rich very quickly from shrimp farming because each "crop" only took a few months and resulted in huge profits. Although the investment costs were (and still are) high to enter into the business (which I will discuss more in a later chapter), farmers were able to recoup that investment in a matter of one or two harvests. The government also subsidized the investment costs of farmers and 
offered credit support to lower the barriers for entering into the industry, all as a way to boost rural economies (Interview data 2014). Dr. Shakti, a fisheries scientist who was involved in the early development of aquaculture in India and continues to be an aquaculture advocate, sat down with me and explained how the shrimp aquaculture industry took hold in India. He explained,

Traditionally shrimp was farmed in rice paddies. I saw this, but the yields were small. I started working with farmers in West Bengal to develop a new way to increase their shrimp outputs. After four months, they made a lot of money - thousands of rupees - enough to buy a new car. We started demonstrations all around the country; we opened demonstration farms in Andhra Pradesh. The government was very happy with the success, and they said they would fund it. The industry started spreading (Interview data 2014).

This government support still exists through the State Fisheries Department, the Marine Products Export Division, and the National Fisheries Development Board (NFDB). For example, NFDB will cover $20 \%$ of aquaculture farmer's investment costs for repairing an existing aquaculture pond/tank, constructing new ponds/tanks, and establishing aquaculture hatcheries (NFDB undated). When I asked shrimp farmers in Poompuhar, why they farm shrimp the answer is virtually always the same: "We can make more money with shrimp than we can with paddy or cotton” (Interview data 2014). "Why not farm fish or crabs?” I asked. "Because shrimp grow faster and the value is better" (Interview data 2014). Every response to this question was always about the economics of shrimp farming.

Other economic factors also encouraged the growth of cultured shrimp. The Government of India allowed for duty exemptions so that businesses could import shrimp feed and seed without any prior clearance. These imported items were also initially 
exempt from quarantine and quality testing, which is no longer legal (Kurien 1997). The government also approved and encouraged the entrance of foreign investors into Indian markets. For example, the Unilever company entered the shrimp aquaculture business in India in 1990 (Kurien 1997). Additionally, the government rapidly privatized large areas of land in some areas of India by transferring government owned coastal land into the ownership of private business owners (Kurien 1997).

This pattern of government support and investment for cultured shrimp that began in the 1990s has continued in India, as growth potential remains high for the industry. A visit to the Tamil Nadu State Fisheries Department website on coastal aquaculture demonstrates the government support for the expansion of the industry. The website states, "The present culture is 4,455 ha. which is only 30 per cent of the estimated potential area of 14,880 ha. readily available for shrimp farm development. Hence there is a wide scope for land based coastal aquaculture development in Tamil Nadu” (http://www.fisheries.tn.gov.in/aquaculture-main.html, accessed October 10, 2014). The interesting part of this quote is that shrimp farming is synonymous with aquaculture, showing how the industry not only dominates in the minds of farmers, but also for the state government. Despite dips in the market due to disease problems, the global demand for shrimp remains high and prices remain high. Investors see that other people are still getting rich off shrimp and want to enter the business too (Interview data 2014). Even during my field research, which took place 24 years after the beginning of the shrimp boom, shrimp still dominates aquaculture practices in the coastal areas of Tamil Nadu, India (a trend I discuss more of in following chapters). 


\section{Issues of Food Security and Social Stratification}

As I mentioned, one of the main development goals behind the changes to global food production was that of food security; a focus on improving people's access and ability to meet their most basic food requirements. Scholars argue that this goal builds upon Malthusian ideologies that experienced a revival in the 1950s, 60s and 70s (Gupta 1998). The logic that guided the development project was the idea that the post-World War II population boom was a threat to global economic stability and a source of poverty in nations such as India because food production could not keep up with population growth. Consequently, industrialized agriculture and fisheries production was a way to increase outputs. Both the Green and Blue Revolutions were originally framed in this way, and contemporary discourses continue to perpetuate this type of framing. For example, in a document produced for the FAO in 2009, the authors state,

As population growth in the region [of Sub-Saharan Africa] places increased pressure on food supply in general and fish supply in particular, capture fisheries will eventually not be able to meet the full demand for fish protein; hence aquaculture must assume an important role in filling the protein gap (Cai et al. 2009).

However, despite the promise of industrialized food production as a means to improve food security in developing areas, both Revolutions have had mixed results. In later chapters, I discuss the implications of aquaculture practices on food security in Poompuhar based on my own data, but here I will address the contending conclusions regarding food security for both the Green and Blue Revolutions.

In reference to the Green Revolution, food production in some areas of India did increase because of HYV crops. Only a year after HYVs were introduced in India, wheat 
production increased by approximately 4 million tons and doubled by the early 1980s (Swaminathan 1996; Kapila and Kapila 2002). Additionally, many agricultural scientists assert that the spread of HYVs ended India’s dependence on foreign imports of food, helping the national economy to grow. Other scholars have demonstrated positive effects on village economic growth, employment opportunities, and quality of life linked to the increase of local food production (Borlaug 2004; Orr 2012). For example, a study analyzing the changes in three Uttar Pradesh villages over a 35-year period since the introduction of HYVs showed that since the beginning of the Green Revolution, famines ended and livelihood security increased (Baker and Jewitt 2007). Baker and Jewitt found that increased crop yields from the use of HYVs, allowed for overall village growth, expanding the non-farm economy. They also found that wages had increased for both men and women because of the improved village economy. Unfortunately, there was evidence of a widening gap between the rich and poor, as people who did not participate in farming did not necessarily benefit, but villagers claimed, "no one went to bed hungry anymore” since the Green Revolution (Baker and Jewitt 2007: 335).

Alternatively, some scholars believe that the Green Revolution has predominately decreased food security. For example, Tarique Niazi (2004) argues that inequalities in land tenure in rural Pakistan meant that many people were excluded from the changes that the Green Revolution brought. This led to problems with employment, decreases in household incomes, and ultimately a decrease in food security. Other studies have also highlighted patterns of land consolidation that accompanied much of the Green Revolution, where large companies or wealthy landowners bought up land and kicked 
tenant farmers off their farms (Freed and Freed 2002). This not only reduced the food security of poor families that lost their land, but also created greater social stratification, as land ownership is often associated with social class and wealth. Additionally, Kamaljit Sangha (2014) argues that any food production gains from the Green Revolution are not sustainable and will ultimately decline. These findings suggest that although food production may have increased in some areas in India, the outcomes were mixed depending on other social impacts such as employment, land tenure, and economic fluctuations.

The Blue Revolution has had a similar mixed record in regards to food security issues. Some scholars assert that aquaculture has improved food security in developing areas. For example, Mahfuzuddin Ahmed and Mylene Lorica measured food security in several Asian countries based on a household consumption model. They concluded that there is “clear evidence of positive income and consumption effects of aquaculture on households” (Ahmed and Lorica 2001: 125). Similarly, Cai et al. (2009) found that tilapia, catfish, and shrimp aquaculture positively contributed to protein supplies available to households in Sub-Saharan countries. However, Cai et al. (2009) admit, as do others, that it is difficult to make generalizations about the impact of aquaculture activities on food security overall, due to a lack of systematic studies (Aguero and Gonzalez 1997; Charles et al. 1997).

Other scholars demonstrate the failure of aquaculture to improve availability of protein within communities, particularly shrimp farming. Shrimp aquaculture in particular has come under scrutiny for its failures related to food security because it often 
involves the conversion of subsistence farming to an export economy (Gujja and FingerStich 1996; Rivera-Ferre 2009). Scholars argue that this makes protein less accessible in poor communities because the fish produced is too expensive for them. Instead of buying other sources of protein in the market, studies have shown that households tend to use their shrimp income to buy other goods, and go without the protein (Abila 2003).

The mixed outcomes of both the Green and Blue Revolutions demonstrate an important commonality, that is, that the success of contributing to food security is largely dependent on the context and implementation strategy of production. Cultural practices, land tenure patterns, environmental conditions, and political regimes can all influence the impacts of food production strategies. As Cai et al. (2009) suggest, more in-depth and systematic studies are needed to assess impacts; that is why ethnographic studies, such as this one, are so essential.

\section{Environmental Issues}

The theme of environmental degradation dominates the critiques of both the Green and Blue Revolutions. In later chapters, I will discuss the specific impacts of aquaculture practices on environmental conditions in Poompuhar, but first I will address the issues as discussed in the literature as it relates to both Revolutions.

One of the main criticisms of both the Green and Blue Revolutions is the causation of polluted or degraded natural resources, namely soil and water. Environmental activist and outspoken critic of industrialized food production regimes, Vandana Shiva, argues that the Green Revolution has led to the contamination of soils in 
the Punjab region of India (Shiva 1991). She argues that the soil contamination arises from the overuse of chemical inputs such as fertilizers and pesticides. Shiva also asserts that the intense water demands of HYV crops, coupled with the intensification of agriculture, causes severe water shortages for some marginalized sections of the community. Additionally, the damming of rivers for irrigation also leads to cases of flooding and the displacement of homes.

Shiva's critiques of the Blue Revolution follow the same arguments. She argues that like industrialized agriculture, shrimp aquaculture has also led to the contamination of drinking water and soils through salinization and runoff of effluents. This has led to the displacement of households as well as conflict within villages (Shiva 2000). She also cites examples of peasant protests against both industrialized agriculture and aquaculture that have occurred in India (Shiva 1991, 2000). For example, on August 15, 1997, coastal villagers marched alongside members of the National Action Committee against Coastal Industrial Aquaculture in support of banning the shrimp farming industry in India (Shiva 2000). Such protests, led by activists such as Vandana Shiva, led to important policy changes regarding the regulation of the commercial aquaculture industry. Only a year later, farmers in the states of Andhra Pradesh and Karnataka protested against the production of genetically modified seeds by burning crops planted as part of a Monsanto demonstration farm (Shiva 2000).

The degradation of soil and water because of the Green and Blue Revolutions is widely documented by other scholars as well. For example, Baker and Jewitt (2007) describe the loss of nutrients in the soil from over exploitation of land from industrial 
agriculture and the disruption of traditional crop rotation methods. Singh and Sindhu (2006) describe the loss of native plant species, which can also degrade soil quality. Additionally, studies have demonstrated that brackish-water aquaculture, namely shrimp farming, often leads to salinization of soils and groundwater (Gujja and Finger-Stich 1996; Primavera 2006; Vandergeest 2007). Paez-Osuna et al. (1998) also showed that shrimp aquaculture has led to coastal water pollution in Mexico from the discharge of untreated pond effluents into water bodies.

In addition to degraded water and soil, the Green and Blue Revolutions have also been critiqued for reducing biodiversity and exacerbating the spread of diseases throughout wild plant and animal populations (Dewalt et al. 1996; Hopkins et al. 1995; Primavera 2006; Sangha 2014; Shiva 1991. These effects are due to the use of monocropping, which is a wide-spread technique of both Revolutions. Mono-cropping is often used in industrialized settings because it increases efficiency and lowers operation costs. However, it dramatically alters local ecologies and may cost farmers more in the longterm because of high instances of disease and pest outbreaks.

With so much attention given to the environmental problems associated with both Revolutions, it is not surprising that the issue of sustainability frequently arises. Many scholars debate whether or not these food production regimes are sustainable or how sustainability can be achieved through better management practices (Barton and Floysand 2010; Falcon et al. 2011; Kutty 2005; Rivera-Ferre 2009). These debates have shifted the development discourse, particularly concerning aquaculture, toward more environmentally-focused objectives. More recent Blue Revolution discourse involves an 
added message that extends beyond poverty reduction and food security. Since the shrimp boom of the late 1980s and 1990s, proponents of industrialized aquaculture combine the rural development rhetoric with discourses aimed at appealing to environmental ethics. International aid organizations such as the Food and Agriculture Organization (FAO), as well as fisheries scientists argue that sustainable aquaculture has the potential to reduce the effects of over-fishing. In other words, they argue that aquaculture can be good for the environment as well as for food security (FAO 2012). This added goal points to a more recent awareness and concern for environmental problems, particularly within the global arena. It also suggests that development managers are either attempting to address critiques of development programs that blame them for causing environmental degradation, or that they are trying to diminish criticisms by highlighting how aquaculture can be seen as minimizing other environmental problems.

\section{Development and the Rule of Experts}

The foundation of both the Green and Blue Revolutions rests upon the application of science and technology to increase outputs in food production. This point has led to what many scholars refer to as "the rule of experts" or the dominance of "technocrats" in development programs (Escobar 2008; Ferguson 1994; Li 2007; Mitchell 2002). In other words, the development of industrial food production industries is guided by scientists, technicians, and development officials rather than members of local communities where the production is actually taking place. In a later chapter, I will discuss specific 
applications of this critique in regards to commercial aquaculture in India, but first I will discuss the discourses involved in the critique.

Scholars argue that the rule of experts hinders participatory development, often leading to many of the problems I have already discussed in this chapter. For example, Timothy Mitchell (2002) highlights how the construction of the Aswan Dam in Egypt, conceived and implemented by technocrats with the goal of improved agriculture, led to a domino effect of environmental health problems. Scholars also argue that a lack of participatory approaches means that the needs of communities are ignored or misrepresented, causing social problems and conflict. Amita Baviskar's research (1995) in the Narmada River Valley in India is a prime example. She demonstrates how technocrats guiding development projects ignore the needs of communities; in this case, marginalized tribal people who protested dam construction. The construction of the Narmada River dam led to the displacement of whole villages and intensified the poverty in the area.

These critiques highlight the point that the technologies of the Green and Blue Revolutions are not necessarily to blame, but the way projects are implemented. Andrew Pearse, a researcher for the United Nations Research Institute for Social Development during the 1970s and 1980s, argues that the changes in social structures, combined with other social factors are what cause problems in development programs (Pearse 1980). He explains that,

These contradictory trends affecting negatively many social groups can in no way be considered to have been 'caused' by the new high-yielding varieties of food grains. Rather they are a product of complex 
interrelationships among and within social systems that happen to have received in some instances additional perturbation from the introduction of the new varieties (Pearse 1980).

Pearse argues for greater involvement of anthropologists and other social scientists in the implementation of development programs. He also recommends holistic policy changes that address the root causes of poverty rather than solely technological fixes. Lipton and Longhurst (2010) also share this perspective. They argue that the Green Revolution is not a "revolution" because it failed to improve the lives of the poor. In order to cause a true revolution, they assert that development planners must take into account existing power structures within communities that serve to perpetuate poverty and disempowerment. Flaherty et al. (2009) make similar arguments about the implementation of the Blue Revolution. They argue that the idea of industrialized aquaculture is not the problem, it is the unsustainable ways in which it is practiced and the lack of regulations that causes environmental and social problems. As a result, they believe that aquaculture practices can be sustainable and help poor communities if there is better coordination between stakeholders and better enforcement of management practices.

The shared critique of both the Green and Blue Revolutions regarding the rule of experts underscores several important points. First, it demonstrates that both Revolutions have similar governance and implementation patterns dominated by technocrats that connect back to the ideologies of the development project. Second, it shows that both Revolutions have a similar record in terms of negative social impacts. Third, like the assertions of Pearse (1980) and others, this critique reveals an underlying solution - that more community participation and social analysis is needed to help plan development projects. Ultimately, it points to hope that programs that are more successful are possible. 


\section{Gender Issues}

Another similarity between the Green and Blue Revolutions is the way in which the impacts are gendered. Scholars such as Shiva (2000) and Sobha (2007) link both Revolutions to changes in gender dynamics and gendered risk. Sobha argues that the Green Revolution is part of a masculinist paradigm because it ignores the activities and needs of women (Sobha 2007). It displaces women from their traditional roles in agriculture, such as collecting organic compost and manure and fodder for livestock. These changing labor patterns can affect the status of women in households, decreasing their agency in household decisions since they contribute less to economic activities (Sobha 2007). Alternatively, in other cases, women’s labor is affected through blocked access to natural resources such as fresh water or firewood due to the privatization of common lands. In these cases, women must travel further to gain access to resources. Shiva (2000) documents such instances in the case of shrimp farming. She describes how village women in Nellore district, India have to work 4-6 extra hours a day to collect fuel wood and drinking water because of environmental problems from shrimp farms.

These critiques highlight how in some cases, the Green and Blue Revolutions have negatively affected women differently than men. Shiva describes these impacts as "the feminization of suffering" (Shiva 2000). These examples also demonstrate how both the Blue and Green Revolutions can affect communities in unforeseen ways, once again pointing to the need for greater engagement with community members and anthropologists in the planning and implementation of development. 


\section{Conclusion}

A dominant theme in aquaculture literature is an analysis of how such practices contribute to the fulfillment of development goals, such as food security and employment. However, there is a need for more scholarship regarding the historical connection of industrialized aquaculture with rural development processes and how and why these processes continue into contemporary times. In this chapter, I have addressed this topic by demonstrating how aquaculture aligns with rural development legacies and strategies in India. I have argued that this connection began with the development project following World War II, sharing its roots with the Green Revolution.

Many scholars have mentioned the connection between both the Green and Blue Revolutions, but their discussions have not explored these similarities in depth. I compared some of the main ideologies and criticisms shared by both Revolutions to underscore their connection. I believe that this helps scholars to understand how global food production aligns with development processes. 


\section{CHAPTER IV. STAKEHOLDER ESTRANGEMENT AND THE CREATION OF ENVIRONMENTAL RISK}

In this chapter, I discuss the disparity between the goals of aquaculture development programs and actual aquaculture practices. I also underscore how the perceptions of extension workers differ from aquaculture practitioners in Poompuhar, India. I argue that the opposing stakeholder perceptions and practices within the commercial aquaculture industry in India are a symptom of what I refer to as “estrangement,” defined as a lack of engagement and participation between aquaculture managers, researchers, and practitioners. I specifically use the word "estrangement” because it denotes a broken relationship between groups; highlighting the fact that initially, aquaculture development programs were designed to benefit communities but presently, the good intentions are overshadowed by a lack of cooperation between stakeholders. The term also highlights the point that aquaculture development workers are not necessarily “outsiders” or “foreigners," but rather they are often members of the community in which they are working but their perspectives and approaches do not match other stakeholders. This estrangement is caused by the technocratic and top-down governance structure of the commercial aquaculture industry. Rather than improving the quality of life and resilience of communities, as aquaculture programs aim, the estrangement creates problems of environmental risk, making the community of Poompuhar more vulnerable.

My argument builds upon the work of anthropologists James Ferguson (1994) and Tania Murray Li (2007), both of whom provide an entry point into the critical 
analysis of development projects. Ferguson argues, “... what is most important about a 'development' project is not so much what it fails to do but what it achieves through its 'side effects'. Rather than repeatedly asking the politically naïve question 'Can aid progammes ever be made really to help poor people?', perhaps we should investigate the more searching question, 'What do aid progammes do besides fail to help poor people?' (Ferguson 1994: 180)”. Ferguson found that development programs could have the effect of expanding bureaucratic state power and reframing political obstacles as technical problems best solved by “experts.” In other words, development programs create a technocratic governance structure. The side effects that Ferguson identified in his ethnographic work do hold true in the case of commercial aquaculture development in India, as development programs reframe the political issue of rural marginalization into a technical problem of how to produce food more efficiently. I agree with Ferguson, that understanding what development programs produce is an important endeavor, although I believe that it is important because the information gained can help development planners adjust their practices so that programs do help poor people.

I found that the side effects of aquaculture development programs in India also mirror the conclusions of Tania Murray Li’s ethnographic work in the Central Sulawesi region of Indonesia. Li found that a mismatch between development goals and those of the community, amplified by a lack of cooperation, led to further marginalization of Sulawesi villagers. She also argues that marginalized communities were blamed for their own impoverishment, thus allowing development managers to legitimize their interventions. The same processes of estrangement and victim blaming are occurring in Poompuhar. 
My argument, that the side effect of aquaculture development in Poompuhar is the creation of environmental risk, contributes to anthropological theory by synthesizing the ideas of Ferguson and Li with those of Blaikie et al. (1994). In their seminal book, At Risk: Natural Hazards, People's Vulnerability, and Disasters (1994), Blaikie and others explain how vulnerabilities to natural hazards can be produced by social, economic, and political processes. However Blaikie et al. do not connect these processes explicitly with development. In this chapter, I demonstrate a connection between development, risk, and vulnerability, which helps us to understand the impacts that development programs have on communities in light of particular failures.

This chapter has two main sections. In the first section, I discuss how estrangement between stakeholders involved in the commercial aquaculture industry develops from technocratic, top-down governance. In the second section, I discuss how this estrangement contributes to environmental problems that in turn make the local community more vulnerable to a variety of hazards.

\section{Technocratic Governance and Stakeholder Estrangement}

My visits to aquaculture research and extension facilities in Tamil Nadu, as well as my interviews with managers, left me with the impression that there was a lot of engagement with the local communities. For example, an RGCA extension worker claimed that in the last three and half years he had trained over 1,750 people in new aquaculture technologies (Interview data 2014). I toured the demonstration farms where the training took place and people could come to see how to farm crab and fish. I also saw pictures of training programs that they had conducted in the past, plastered in 
pamphlets and newsletters. However, extension workers spoke to me about how despite their efforts, the technologies that they were promoting were not taking hold in the community. Dr. D. Karan, an extension worker at a mud crab fattening demonstration farm in the region lamented, "Still people are keen on shrimp, but slowly farmers are coming [to train with us]. But the time investment is a deterrent. If they have disease problems, then they come.” His explanation underscores the persistence of local interest in shrimp farming and that people are only willing to switch to other aquaculture practices if they are desperate due to disease outbreaks in their stock. Other interviews with extension workers highlighted the same sentiments, explaining that the only thing people are interested in farming is shrimp because it has such a proven reputation for making large profits. They also mentioned reluctance from fisher folk for switching livelihood techniques, from fishing on the open ocean to raising fish or crustaceans using aquaculture techniques. One of the major reasons for this reluctance, according to extension workers, is the amount of waiting time required for aquaculture. Dr. D. Karan, explained, "Farmers come for training with some interest, and once they learn they become more interested. But one challenge we are struggling with is that farmers don't want to wait so long for a harvest. For 8 months what else can they do?” His mention of 8 months is in reference to the amount of time it takes to harvest cultured seabass, an aquaculture strategy that many programs, such as his, promote. In contrast, a shrimp harvest takes about half the time, making it more attractive to practitioners. His question, “what else can they do?” refers to the problem of lack of employment. In other words, while farmers are waiting the 8 months for their seabass to mature, they have no other means of income. This is a hardship for their families, not only because it is hard for 
them to survive in the meantime, but also because the waiting period may cause farmers to be restless, stressed, and even depressed. Several wives of capture fishermen hinted at this problem when they talked about the off-season times when their husbands are out of work. They complained that when their husbands are out of work they drink alcohol and cause problems for the rest of the family. I believe that the off-season periods for fishermen during the monsoon are most likely equivalent to the waiting period between harvests in aquaculture.

My interviews with the people who practice aquaculture as a source of income revealed a different perspective. When I interviewed these aquaculture practitioners, most of them had never taken any training from extension programs. My interviews also revealed that they had little interaction with managers, researchers, or extension workers. Shrimp farmers complained, “[scientists and managers] just sit at their desks in their offices and talk a lot about the good things they are doing, rather than coming out and actually visiting our farms” (Interview data 2014). In fact, most of the shrimp farms at my research site were operating illegally in 2014 because no one from the Coastal Aquaculture Authority had come around to renew the licenses.

My observations and interviews uncovered significant opposing perspectives regarding the success of aquaculture development programs and the reasons why they may be failing. From the perspective of aquaculture managers and extension workers, progress seemed to be measured by the number of programs rather than the number of successful new aquaculture endeavors. For example, when I visited an aquaculture extension institute the workers boasted to me about how many people they had trained and that they were promoting 8 different aquaculture technologies including tilapia, 
grouper, mud-crab, and seabass. However, there were no statistics about how many farms were actually practicing such technologies. There was also limited follow up with people after they participated in training programs. Any problems with aquaculture development programs were attributed to the stubbornness of community members and a lack of public education that limited the ability of people to implement new livelihood strategies. Other scholars, such as Jenny Springer (2000), have also highlighted the custom of development workers in India describing rural community members as being "stuck in traditional ways of thinking and doing” (Springer 2000:91). These conclusions demonstrate how blame is shifted away from development workers and onto the community, making the community solely responsible for its own problems. It also shows how failure of development programs are attributed to a moral failing or character flaw within the community, suggesting that development workers may believe that community members cause their own poverty.

Alternatively, from the perspective of aquaculture practitioners, their problems stemmed from a lack of "care" from those managing the industry. In other words, aquaculture practitioners felt as though they were not getting the right attention or resources that they needed from researchers and managers. I attribute these opposing perspectives to what I refer to as "estrangement," a lack of engagement and participation between aquaculture managers, researchers and practitioners due to the technocratic, topdown structure of aquaculture governance.

I use the word estrangement because it refers to a relationship between people or groups of people that are indifferent towards each other or are no longer on friendly terms with each other. I believe this word fits the current relationship between aquaculture 
practitioners and technicians because at the beginning of the Blue Revolution people were hopeful about the potential of commercial aquaculture. The literature was filled with the promise of how aquaculture could contribute to the economy and solve problems of poverty. Now, publications that are more recent talk about mitigating the problems caused by aquaculture such as environmental degradation (which I will explain more in later sections). However as I will discuss, development initiatives now breed mistrust, blame, and animosity between community members and development workers. Consequently, there is a separation between the two groups that I describe as estrangement. Additionally, I use the term governance to refer to the institutions and structures that control aquaculture research and management.

The technocratic, top-down governance exhibits in four main ways. First, although my research revealed that aquaculture governance institutions acknowledge the importance of participatory approaches in their program goals, they do not have clear action plans to meet these goals. For example, The Central Marine Fisheries Research Institute, one of the main aquaculture research institutes in India had this to say about participatory approaches in the industry: "Resource management can succeed only with the involvement and participation of all the stakeholders in the sector as well those from relevant non-fishery sectors. This involves developing vital links with all stakeholders (CMFRI 2015:31).” This short paragraph, found on the second to last page, was printed in a document titled Vision-2050 that was produced as a guide for future efforts in aquaculture research and development. No other details are given in the document about how such participation is to be reached or what stakeholder groups should be involved. It is a classic example of the vague types of references to participatory approaches that are 
common in the materials produced by aquaculture research institutes and extension programs. In addition, rather than consulting practitioners concerning industry problems, such as disease outbreaks, managers rely on technocratic fixes. For example, aquaculture technicians recommend special fish breeding programs to avoid disease, "bioremediation” of disease using probiotics and enzymes, and the construction of more laboratories for research (Yadava 2002). Li argues, as do I, that without strong practitioner engagement, technocratic fixes will only be stopgap measures that do not address the root of problems. Consequently, the structural issues that cause the problems in the first place will continue, further marginalizing impoverished communities (Li 2007).

In addition to a lack of participation between aquaculture development managers and local communities, there is also a lack of participation among aquaculture technicians. Dr. Ahmad, a professor and researcher at an Indian fisheries college explained that there is a major weakness in aquaculture development because there is a lack of collaboration between government institutes and research universities. He attributed this to bureaucratic “red tape,” financing difficulties, decentralization of aquaculture management, and a trend in Indian academia to compete with colleagues rather than collaborate. As an example from his own experiences, he told me about how he spent years developing pearl aquaculture but when he submitted his research so that it could be added to extension programs, it was rejected. According to him, this was because his research competed with other colleagues. As a result, he had binders full of research and examples of successful cultured pearls that he eagerly showed me, just 
sitting, collecting dust in his office. This additional layer of estrangement intensifies the struggle to provide successful aquaculture development programs.

Second, there is a mismatch between the groups of people that aquaculture extension programs target and those actually interested in (and capable of) participating in the industry. Aquaculture extension programs target women and fishing folk because these two sections of the population are some of the most impoverished people in India (Interview data 2014). Women are specifically targeted as well, because of particular development agendas influenced by feminist discourses that began in the late 1970s. Prior to that time, there were few to none specific development programs for women. However studies emerged, highlighting the trend that women seemed to be impacted differently than men by development programs and in some cases, the rights and status of women were even negatively impacted by development programs. Additionally, studies found that if the status and economic agency of women improved within communities, often the overall quality of life improved for the community (Razavi and Miller 1995; Khan 2011). Liberal feminists realized that a different approach to development had to be implemented. As a result, they pushed for women to be a central focus of development strategies. In 1976, the United Nations declared it a "Decade for Women,” officially bringing women's issues into the development sphere and thus heralding a new era of development. Since then, many development programs have tailored programs specifically for the advancement of women, a trend that carries over into aquaculture extension.

Many of the aquaculture research institutes such as the Rajiv Gandhi Centre for Aquaculture (RGCA) and the Central Institute of Brackishwater Aquaculture (CIBA) 
have Self Help Group (SHG) training and support for women. For example, CIBA has implemented women's only SHGs for crab fattening and shrimp feed production (CIBA 2011). The M.S. Swaminathan Research Foundation (MSSRF) Fish For All Centre in Poompuhar also has several women's only aquaculture training programs. One ongoing project started in 2006, $3 \mathrm{~km}$ outside of Poompuhar, involves 15 women from the "SC" community, one of the lowest castes in India. MSSRF trained and funded them to culture carp species in a 2-hectare pond. MSSRF has another similar project in a nearby village that involves 32 women.

It is important to note that the majority of women targeted for these aquaculture extension programs are also part of the fishing community, rather than the agricultural community. This highlights the sole focus of extension to fisher folk. The Tamil Nadu Fisheries Department also specifically states on their website that one of their goals is the "upliftment of poor fisherfolk living in Fishing villages” through the development of Fisheries Co-Operative Societies that include aquaculture activities (http://www.fisheries.tn.gov.in/tsunami-main.html, accessed 3/29/2016). Additionally, the extension manager at MSSRF Fish For All Centre related an almost identical objective for his projects. He explained, "The goal is to boost up the fishermen" (Interview data 2014).

However, none of the aquaculture farms in Poompuhar employs women and people who are not fisher folk own most of the aquaculture farms. Why is there such a contradiction between development efforts and practice? When asked why aquaculture farms are a male-dominated if not exclusively male space, practitioners explained to me that it has to do with the type of labor and the long hours. Maintaining aquaculture farms, 
particularly shrimp farms, is considered labor intensive and requires certain knowledge about water quality and shrimp ecology. That type of work is not considered suitable for women in the village. There is also the issue of safety, as aquaculture farms require workers to practically live on site to protect the ponds from theft and vandalism. Such a job, that would require a woman to be away from her family during the night, is not an option for women in a traditional village where gender rules dictate that they should be in the domestic sphere.

The majority of aquaculture farm owners are also not from the fishing community, but rather from the agricultural community. I found that this was the case because aquaculture practices generally require land, which fisher folk typically do not have. Most of the land in the village is owned by families that were traditionally farmers, making it easier for those families to transition to aquaculture (Interview data 2014).

The mismatch between aquaculture extension target populations and actual practitioners demonstrates that extension workers do not understand the needs or customs of the local community. I also believe that it points to the failure of development organizations to incentivize entry into the industry or to reduce barriers that make it difficult for people to start an aquaculture business.

Studies show that many obstacles can serve to bar people from entering into the aquaculture industry. Ramachandra Bhatta and Mahadev Bhat’s research in Karnataka, India revealed that three main types of barriers exist: capital, technical, and organizational (Bhatta and Bhat 1998). Capital barriers refers to the difficulty of accessing credit or financial backing for people interested in entering the shrimp aquaculture industry or for paying advance rent to lease land before the harvest season. 
Technical barriers refers to the lack of specific knowledge needed to manage a shrimp farm, generally a problem for those who do not attend training sessions or have an education in fishery science. Organizational barriers include the difficulty in organizing aquaculture practitioner groups or establishing a consensus on management practices because the type of people involved in shrimp farming is too heterogeneous in some areas. Additionally, the large number of people trying to enter the industry means that the group dynamic is ever changing, which also makes it difficult to establish a working order. This can lead to conflicts within the community.

My interviews revealed similar barriers. First, a lack of training can serve as an obstacle because aquaculture requires certain knowledge about fish life cycles, water quality, and technology. Many of the shrimp farmers I interviewed admitted that they started without training or knowledge and just copied what their successful neighbors were doing. However, operating in this way is risky and is probably the reason so many farms failed in the 1990s from disease outbreaks and poor management. A second obstacle is access to land. As I discussed earlier, most of the aquaculture farm owners in Poompuhar are from the agricultural community because they already owned land. Many people are barred from the industry if they do not own land or if they do not have the money to lease land (Interview data 2014). This leads to the third obstacle, which is lack of financial resources. It is very expensive to construct aquaculture ponds and maintain them because of the equipment, electricity, and input costs. Consequently, in order to own an aquaculture farm, specifically a shrimp farm, one must be financially "well-off" or go into partnership with several people (an option that some people do). Several government agencies such as the Marine Products Export Development Authority 
(MPEDA) and the Fisheries Department offer subsidies for aquaculture pond construction and maintenance, but once again, the majority of owners do not take advantage of these offers. The reason for this leads us to the final obstacle, which is navigating bureaucracy. My interviews showed that people know about subsidies and how to register their aquaculture farms, but often they cannot start their aquaculture farm because the process is too complicated and lengthy. Some aquaculture farmers told me they had applied for subsidies but were denied and they did not understand why. Additionally, almost all of the shrimp farms in Poompuhar were operating "illegally" at the time of the research project because they were unregistered with the Coastal Aquaculture Authority (CAA), the managing government body. The reason, according to the shrimp farmers in Poompuhar, was that the CAA did not have enough people working and consequently had not come to survey the area, which is necessary for renewal of licenses. This lack of regulatory capacity is something that various stakeholders continually mentioned, even amongst development practitioners. In other words, people kept complaining that the CAA did not have enough funding to support enough staff, and that aquaculture regulations were not enforced.

Third, there are only a few NGOs and other community organizations that specialize in aquaculture related issues. During my fieldwork in India, I tried to find aquaculture related NGOs, so that I could interview staff and learn more about the community side of the industry. However, during my search in Tamil Nadu, I was only able to find one group, the Aquaculture Foundation of India, which is actually comprised of only one man. Other groups resulted in similar disappointments; in many cases they were either defunct or had moved on to other social issues. The shrimp farmers in 
Poompuhar have organized themselves into a type of collective that meets before each shrimp season to talk about aquaculture techniques, but there is little communication between the group and aquaculture technicians. Development scholars have demonstrated that NGOs can be an effective intermediary between government groups and communities, boosting the success of participatory development programs. For example, Vasconcellos and Sobrinho's (2015) research revealed how the participation of NGOs helped a community in the Brazilian Amazon contribute their culture and knowledge to the socio-environmental development program, Proambiente. Vasconcelloes and Sobrinho argue that this engagement empowered the local community and allowed the development program to address the community's specific needs, which was linking environmental conservation to small-scale family based production. With a lack of aquaculture-related NGOs and other community groups in India, it is easy to see how there can be a lack of engagement between practitioners, technicians, and the wider community. Even the main research institutes for aquaculture mention a lack of NGO involvement in their annual reports.

Fourth, the community of aquaculture practitioners lacks trust in and respect for governance structures. This was evident in my interviews when I asked whether or not practitioners had participated in specialized aquaculture training. The responses were always along the lines of “Of course not!” The underlying assumption being that it was a waste of time because there was nothing for the farmers to gain from extension programs. Out of the 25 shrimp farmers I interviewed in Poompuhar, only two of them had received specialized aquaculture training (both from MPEDA). Shrimp farmers, in particular, also shared experiences of getting conflicting information from different types of aquaculture 
technicians, which made them confused about whom to trust. This results in aquaculture practitioners avoiding training programs or ignoring advice of aquaculture managers. I believe this distrust stems from a lack of participatory approaches as well as the failure of governance institutions to meet the needs of the community. Consequently, this fourth reason is part of a feedback loop that continually intensifies the estrangement.

\section{The Creation of Environmental Risk}

The issue of estrangement is significant because it has consequences throughout the wider community through the creation of environmental risk. I conceptualize environmental risk in a two-pronged way: 1) as a situation or context that has the potential to cause damage or adverse effects upon the physical environment such as water, soils, and/or ecosystems, and 2) environmental hazards that put communities at risk for further vulnerability. This conceptualization builds upon the work of Ulrich Beck (1992), who theorizes that contemporary risks are a social construction of modernization. I argue that the lack of cooperation and participation between aquaculture governance institutions and practitioners results in the failure of extension programs and dissuades practitioners from making changes to their practices. Consequently, environmental problems arise, making communities more vulnerable to causes of poverty and environmental disturbance. In this way, I am applying the concept of risk and vulnerability to the analysis of development programs. I believe that this can be a productive marriage of ideas because development programs inherently target vulnerable communities; therefore, it is important to know how programs may add to these vulnerabilities through the creation of risks. 
The creation of environmental risk is particularly evident at my research site through reported cases of water and soil salinization linked to shrimp aquaculture, an environmental impact of aquaculture that studies have also shown in other areas (Bhat and Bhatta 2004; Dierberg and Kiattisimkul 1996; Swapan and Gavin 2010). The issue of salinization arises from the use of brackish-water in manufactured ponds needed to raise farmed shrimp. In the case of Poompuhar, shrimp farmers excavate hectare-sized ponds measuring approximately 3 feet deep, either using a backhoe or by hand. The ponds are then filled with a mixture of brackish river water and bore well water, until the salinity is within the ideal range for Litopenaeus vannamei (the species of shrimp farmed in the area). I sampled water from 9 shrimp ponds in Poompuhar and using a refractometer I found that salinities ranged from $11-25 \mathrm{ppt}$, with a mean at $20 \mathrm{ppt}$. These salinities are well above the range of freshwater, which is 0-0.5 ppt. This average aligns with the life cycle needs of $L$. vannamei species of shrimp, which is actually very tolerant of a wide range of salinity (1-40 ppt) but has the best growth rates at 10-15 ppt (Davis et al. 2004; Wyban and Sweeny 1991). The problem with the use of brackish water is that high concentrations of salt build up in the soil and can leach into adjacent soils from pond seepage. Seepage refers to water that leaks or infiltrates from the shrimp ponds through the earthen walls into adjacent canals, soils, and fields. This happens more frequently if the soil is porous such as with sandy soil, as opposed to clay, or if the soil surrounding the ponds is unsaturated.

While walking around the shrimp ponds in Poompuhar, it was apparent that seepage was taking place on some farms. It was evident from water pooling on the 
opposite side of pond walls and damp spots on the walls themselves (see Figure 4). This is no surprise, considering the fact that the soil in Poompuhar is very sandy. Some shrimp farmers even mentioned it as a problem that they face in maintaining their farms.

Research studies have found that the effects of seepage from shrimp ponds is salinization of surrounding soils, decreased productivity of nearby agriculture, and stunted vegetation (Barraclough and Finger-Stich 1996; Lewis et al. 2003). 


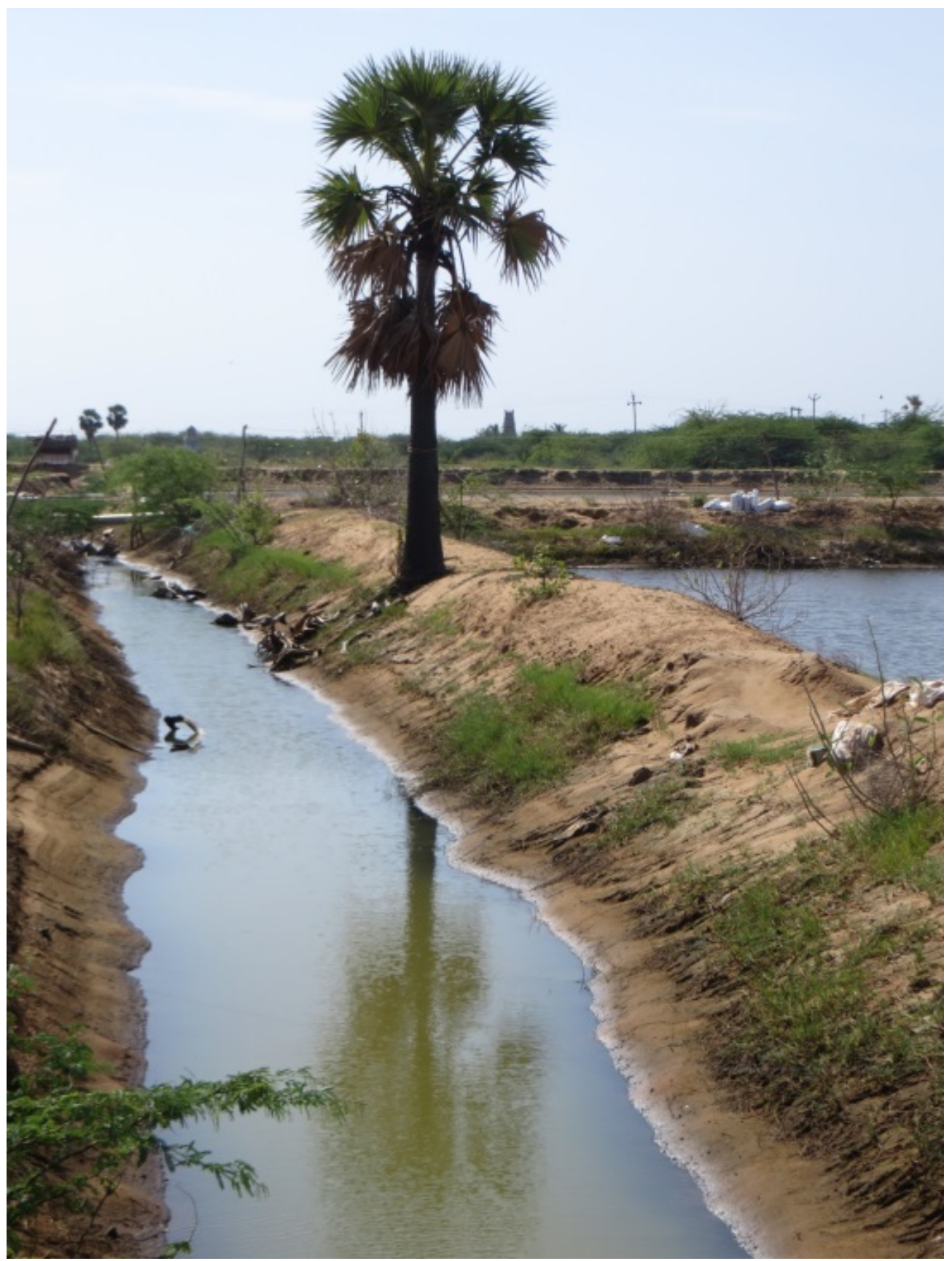

Figure 4. Water Seepage from Shrimp Pond

The build-up of salt mixed with shrimp waste materials (ammonia) was also evident as I visited shrimp farms. After each harvest, shrimp farmers have to dig out this build-up of wastes from the bottom of the drained ponds (see Figure 5). 


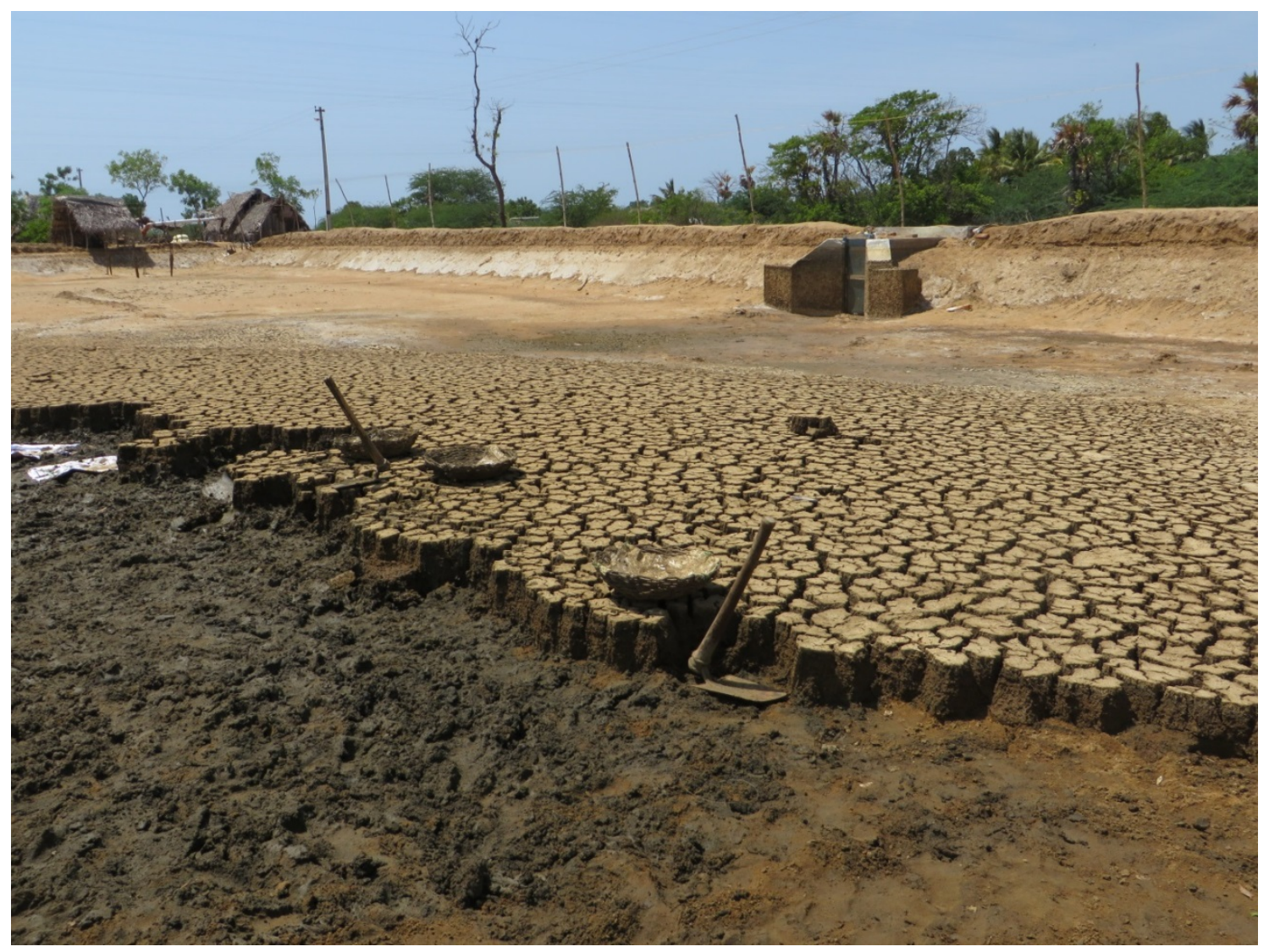

Figure 5. Shrimp Pond Waste Removal

The waste soils are used to build up the sides of the ponds, and therefore are never actually removed from the environment. The ammonia can also seep into nearby farms, contaminating ground water and soils (Interview data 2014).

Of the 77 households I surveyed, 23 of them, nearly 30\%, reported problems with contaminated water or soil from high levels of salt or ammonia. The affected properties were located near or adjacent to shrimp farms operating in the village and many of the property owners believe that aquaculture activities are to blame for the salinization. However, another popular theory amongst landowners is that the groundwater and soil changes occurred from the tsunami. This is because they started to notice the changes around the same time and the tsunami caused visibly dramatic changes to the coastal 
landscape, inundating fields and destroying farms. It is understandable that people would equate such a significant event with changes to their environment. I spoke with the director of one of the local aquaculture research institutes about this problem, a fisheries scientist himself, and asked if it was possible that the tsunami was indeed the reason for some or all of the environmental changes. He replied, "The tsunami could not be the reason for groundwater changes - that was a short-term change. The reason is excessive shrimp farming” (Interview data 2014). Hydrological studies conducted after the tsunami support his claim. For example, research conducted in Sri Lanka, another area affected by the 2004 tsunami, revealed that although freshwater wells were salinized from the tsunami, salinity rapidly decreased in a matter of months, from approximately 29,400 $\mu \mathrm{S} / \mathrm{cm}$ to $3200 \mu \mathrm{S} / \mathrm{cm}$ (Villholth et al. 2005). This was a result of rainfall and natural groundwater recharge. The study team estimated that salinity would decrease to pretsunami levels after the course of another rainy season. A study conducted in Nagapattinam district, where Poompuhar is located, also found that 6 months after the tsunami, soil quality was nearing pre-tsunami conditions (Chandrasekharan et al. 2008). However, Chandrasekharan's team observed that the groundwater in areas was still too saline for irrigation or drinking but that high intensity rain events would most likely flush out the salt. Consequently, long-term salinization of soils and groundwater from the tsunami is unlikely.

Of the 23 households that reported problems with contaminated water or soil, 17 of them (nearly 74\%) reported that agriculture is their main livelihood strategy. This suggests that environmental changes to water and soil affects members of the agriculture community disproportionately, making them more vulnerable to such changes. This 
makes sense because households in Poompuhar that practice agriculture directly rely on groundwater and soil for their survival and interact with these factors on a daily basis. Therefore, such households would be more aware of environmental changes and would be most affected. Of the 17 households that reported environmental problems and practice agriculture, 8 of them reported that the changes to the soil and groundwater had negatively affected their agrarian livelihoods, some to the point where they had to abandon farming altogether.

One landowner I interviewed, Rajiv, is a common example of the struggles farmers in Poompuhar face due to environmental changes. He explained to me that his land used to be one of the most productive plots of groundnut in the village. In recent years, the soil became too saline and his groundnut crops failed. Rajiv had to quit farming and he now uses his land to produce mud-bricks. Mud-brick production involves the digging out of clay to make bricks that are then sold and used for construction of homes and buildings. The process causes the erosion of top soils, which strips the land of nutrients, leading to a dusty, barren landscape that can no longer support any type of vegetation.

The family of my translator, Vasanthakumar, owns land next to shrimp ponds as well. His family had to abandon their ancestral homestead where they lived and grew vegetables because the land and drinking water became contaminated with salt. The land is now uninhabited and overgrown with thorny underbrush, Prosopis juliflora, an invasive bush that can withstand arid climates and higher levels of salt in the soil. Their old house sits crumbling as it slowly reverts to wilderness (See Figure 6). 


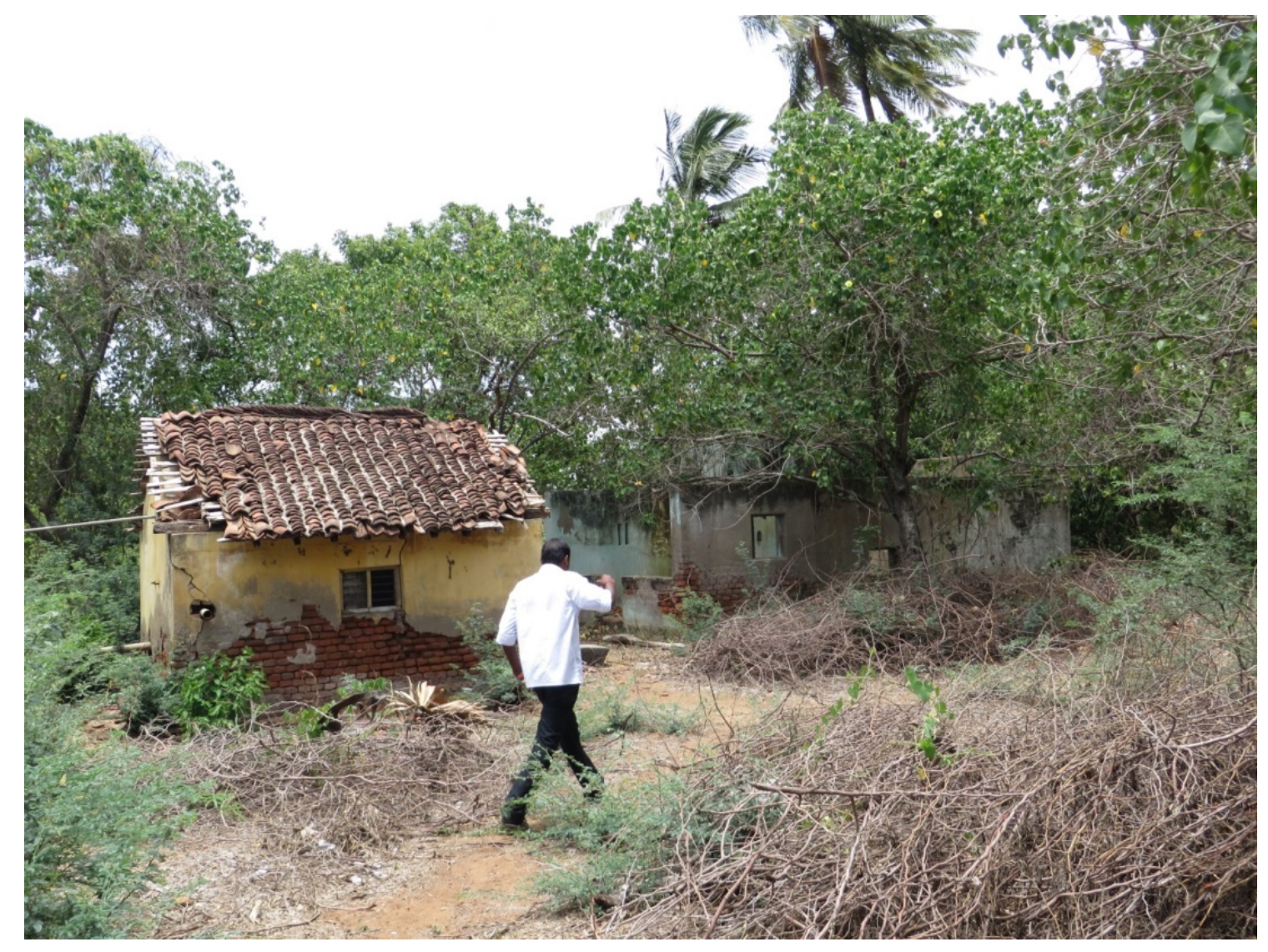

Figure 6. Vasanthakumar’s Abandoned Ancestral Home

A small pond on the property, that Vasanthakumar explains used to be freshwater, is now salty. Many of the trees are also dying, what he says is a result of high concentrations of salt in the soil. The property is only used now for harvesting coconuts from some remaining trees and collecting firewood for cook fires. As we walked around his old homestead, he described what life was like for his family then. He said, "When we lived here we were all so happy, so many people were always around and it was always noisy with the sound of children, dogs, and chickens” (Interview data 2014). He seemed sad about having to leave that land. His family has since shifted to another plot of land that is much smaller, forcing some of his extended family to live elsewhere. It is only about a 
mile away from their old home, but their conditions have greatly changed because they have less space. They have less room for raising animals such as chickens and goats, cutting into their household income and subsistence. His family also has another problem because of salt intrusion - the land on which they grow rice and cotton (a separate plot of land midway between their old house and their new one, situated along the riverbank) is slowly being taken over by Prosopis juliflora (See Figure 7).

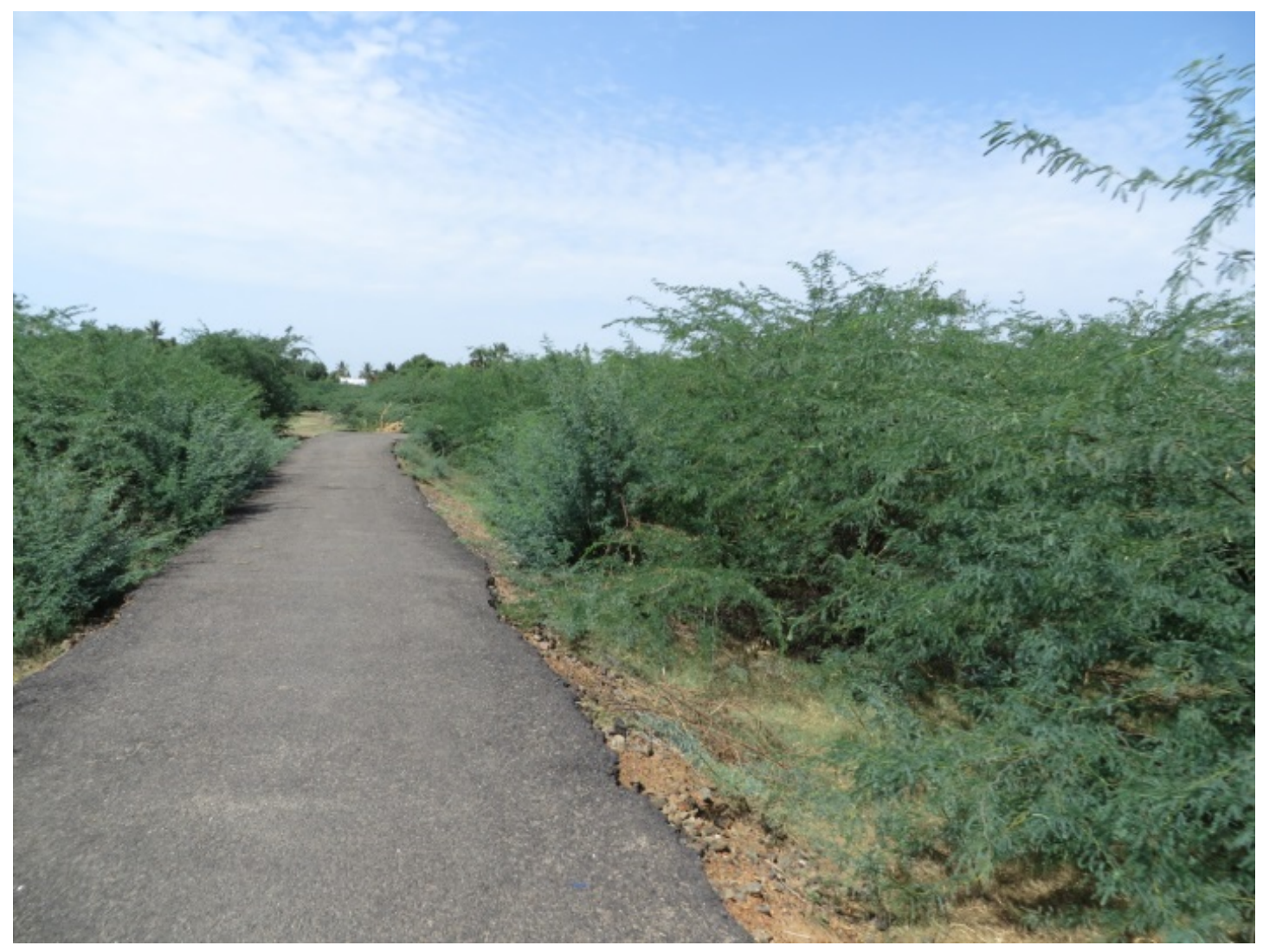

Figure 7. Invasive Growth of Prosopis juliflora in Nagapattinam District

It makes the land unusable for grazing goats and cattle, and is a constant struggle to clear it away when rotating crop areas. They are not the only ones battling this bush; I noticed that it is widespread throughout the wider Nagapattinam district. The salinization of soils 
and groundwater in Poompuhar make it a prime location for such a plant to take root because it can out-compete less hardy vegetation.

The first-hand accounts from community members that I interviewed reveal that the changes to soil and water in Poompuhar are so impactful, that they are changing the livelihood structure of the community. In some cases, such as Rajiv, people are leaving an agrarian livelihood and using their land for other purposes. In other cases, such as Vasasnthakumar's family, the land goes fallow and may be used only for grazing of goats and cattle. However, what seems to be an increasing trend is that more people are switching to shrimp aquaculture themselves. According to a shrimp farm survey conducted by the M.S. Swaminathan Foundation Fish for All Centre, in 2008 there were 17 shrimp farms consisting of 34 ponds in Poompuhar. In 2014, during my field research, there were 50 farms with nearly 100 ponds (Survey data 2014). My interviews reveal that one of the main causes for an increase in local shrimp farms is a sense of inevitability or pressure, due to the salinization of soil and water. People reported that they decided to switch to shrimp farming because they did not know what else to do with their land since they could no longer grow rice and groundnut.

I discuss these agrarian changes more in a following chapter, but what is relevant to risk and vulnerability is the decrease in livelihood diversity due to these environmental changes. I argue that the problems of salinization have reduced the flexibility that landowning families have in terms of how they use their land, and serve to siphon more and more households towards the mono cropping of shrimp. Consequently, households that relied on different crops throughout the year (ex: cotton in the dry season, rice during 
monsoon) are now reliant on only one source of income, which makes them more vulnerable to economic hardships if the shrimp enterprise were to fail. Rather than improving livelihood diversity as aquaculture development programs aim, shrimp aquaculture is causing further livelihood homogeneity.

Problems with salinization of water also make households more vulnerable to drinking water shortages, which is a serious problem for an area like Poompuhar that already suffers from a lack of infrastructure such as indoor plumbing in many homes. In my interviews and household surveys, no one reported problems with drinking water due to salinization. However, it is highly likely that with an increase in shrimp farming activities, drinking water will be affected.

Another vulnerability introduced to Poompuhar as a result of environmental problems, is an increase in social conflict between different land users. In my interviews with landowners affected by salinization, there was an underlying feeling of anger and resentment toward shrimp farmers. So far, these feelings had resulted in cases of vandalism and theft on some shrimp farms in the village. Shrimp farm owners complained to me that members of the community had come on to their property at night and stolen shrimp. In fact, because of the threat of vandalism, every shrimp farm I visited in Poompuhar and even the wider Nagapattinam district had at least one person that stayed on the farm overnight as security. In other regions in India and around the world, environmental problems from shrimp farming have escalated to violent clashes between community members (Interview data 2014, Stonich and Bailey 2000). I would not be surprised if similar events occurred in Poompuhar if salinization problems continue. 
In addition to significant changes in water and soil quality, another way in which shrimp farming in particular contributes to environmental risk is the introduction of nonnative species into local bodies of water. This creates the potential for declines in natural fish stocks, as well as economic problems for capture fishermen. Until 2008, shrimp farmers in Poompuhar only cultured the native Indian species, Penaeus monodon (Giant Tiger Prawn). However, currently, every shrimp farmer in Poompuhar is culturing the Pacific White Leg species, Litopenaeus vannamei, which is endemic to the Pacific Ocean (Survey data 2014). According to my interviews with shrimp farmers, two of the main reasons for this switch are 1) to avoid problems with disease and 2) higher market prices. Every shrimp farmer that I interviewed who had previously farmed Giant Tiger Prawn mentioned problems with disease outbreaks, particularly "White Spot Syndrome.” In 2007 and 2008, shrimp disease outbreaks were particularly widespread in India, causing a significant decline in cultured shrimp production (Interview data 2014). Table 2 shows that between 2006 and 2008 total shrimp aquaculture production in India declined 57,747 metric tonnes. In response to these disease problems, aquaculture scientists developed "Specific Pathogen Free” strains of L. vannamei brood stock that promised lower risks of disease. In November 2008, the Government of India issued a notification allowing for the legal import of the non-native species of shrimp. This served as an incentive for shrimp farmers to switch species (Interview data 2014). Table 2 shows that after the introduction of L. vannamei in India, shrimp production increased in 2009 and then dramatically increased again in 2011. 


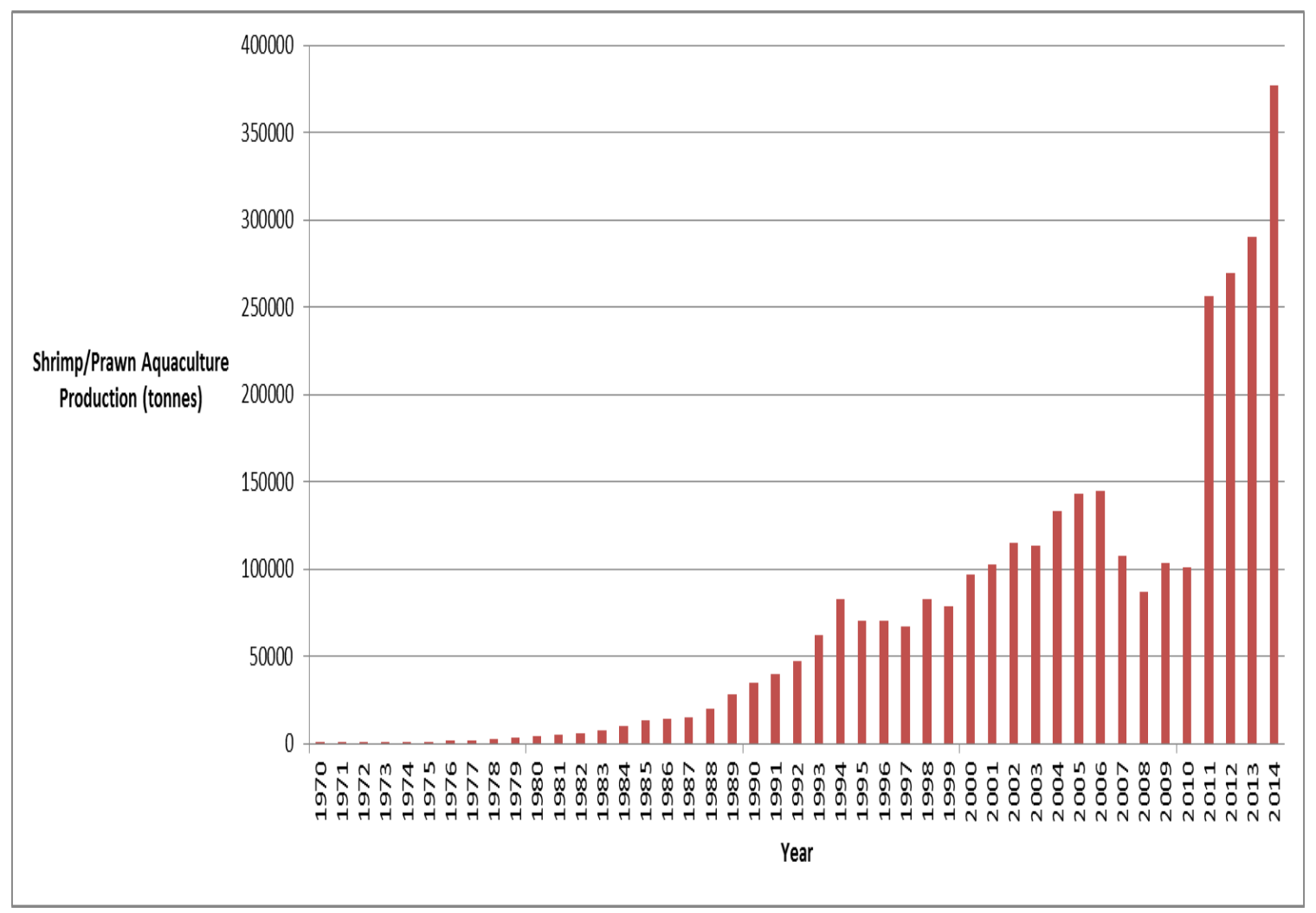

Table 2. Total shrimp and prawn aquaculture production in India by year (FAO).

The other main reason for the shift in production is the dramatic difference in market value of L. vannamei versus $P$. monodon. My research revealed that shrimp farmers in Poompuhar received between 90 and 250 rupees per kilogram of cultured Tiger Shrimp, compared to 450-620 rupees per kilogram of Pacific White Leg Shrimp. An explanation of why this difference exists was summed up well in an interview I had with Arjun, one of the most successful shrimp farmers in Poompuhar. He explained,

It has more edible flesh so that is why the international market prefers it. Most shrimp are exported headless. Tiger prawns have a head to body ratio of about 60-40, whereas vannamei it is reversed. So compared to tiger prawn, there is more body (Interview data 2014). 
This reasoning is logical and reveals a certain trend in international consumption preferences: that bigger really is better when it comes to seafood. In fact, from my interviews with individuals from a shrimp export company, I found that they believe that consumers equate size with quality. Cultured shrimp are only considered acceptable for export markets if they meet certain minimum size parameters, otherwise they are deemed "low quality" and are sold in local markets. Another reason that L.vannamei may be preferred in Japan and the US (the main importers of shrimp), is due to its familiarity of taste. Because L. vannamei is endemic to those areas, consumers in Japan and the U.S. are used to eating that variety of shrimp, making it a familiar product with a recognizable taste. Arjun explained to me that $L$. vannamei has a different taste than that of $P$. monodon; he described it as "softer." According to him, local people do not like the taste of L. vannamei but “foreigners” do. Consequently, L. vannamei has a higher value in the export market.

When I visited local fish markets and watched fishing boats bring in their catch around Nagapattinam district, I found that fishermen were catching L. vannamei shrimp. Fishermen were selling the Pacific White Leg shrimp alongside the Giant Tiger Prawn, which is still the main variety caught in the Bay of Bengal. Their explanation of why they are suddenly catching a non-native species of shrimp in local waters is that L.vannamei, the most popular type of shrimp currently farmed in South India, is escaping shrimp farm ponds through wastewater discharge and making their way into the ocean through river ways. Once the shrimp are in the ocean, they are reproducing and establishing a thriving population. Shrimp farms try to avoid this problem by filtering the water before it 
discharges by placing mesh membranes at the sluice gates of each pond. As the shrimp pond water empties out into drainage canals, it flows through these filters. However, it is possible that some small shrimp make it through the mesh filters.

Other studies in different shrimp farming regions have already documented the introduction of non-native shrimp species into wild populations due to aquaculture. Penaeus merguiensis, commonly known as the banana prawn and endemic to the IndoWest Pacific region, has been introduced in Fiji (Briggs et al. 2004). However, the impacts of the introduction of non-native shrimp species on the ecosystem is not well understood (Gillet 2008). Some studies suggest that disease outbreaks in cultured stock may spread to wild populations and cause die-offs (Briggs et al. 2004; Clay 2004). Unfortunately, there are not any studies involving the South Indian coastal region and fishermen in Nagapattinam did not seem concerned about the issue. I mentioned the topic of $L$. vannamei shrimp escaping into local water bodies during one of my interviews at a local aquaculture research institute, and asked if there was concern over the spread of non-native species of shrimp in the Bay of Bengal. The researcher skirted the question and left me without an answer. I am not sure if this is because he did not want to talk about it, or if he did not have anything to say about it; it seems as though this potentially significant environmental change is not getting the attention it deserves. I believe that inattention to the spread of non-native species of shrimp in local waters puts the environment at risk of unintended and potentially catastrophic effects such as spread of diseases and native population declines. Ultimately, the livelihoods of local fishermen would be affected if their catches declined, creating more vulnerability to poverty. 


\section{Conclusion}

Thus far, scholars and development organizations such as the Food and Agriculture Organization (FAO) have attributed the environmental problems associated with shrimp aquaculture to incorrect operating procedures by aquaculture practitioners (FAO 2007). Ultimately, they blame any problems on the practitioner and tie issues to a lack of education and training, legitimizing the need for technocrats and their solutions. This process, which serves to de-politicize social problems, is one of the main side effects of development that Ferguson found in his research as well. While most aquaculture practitioners do lack formal training, that does not mean that they do not have specialized knowledge.

I do not believe that merely providing more training programs will solve the problem. It is evident that that approach has already failed, since the amount of aquaculture extension programs is increasing, yet the issue of environmental problems associated with shrimp farming has not decreased since issues first arose in the 1990s (FAO 2007; Lewis et al. 2003). My analysis in this chapter demonstrates that the root cause of these problems, conceptualized as environmental risk, is a complex issue of estrangement between aquaculture technicians and practitioners, combined with an environmental incompatibility between current aquaculture practices and agriculture. The blame does not rest upon a single stakeholder group, rather environmental risks are a product of a systemic mismatch between development goals, practices, and the needs of the community. Additionally, the creation of environmental risk also has implications for community resilience; as risks would limit the ability of community members to overcome disturbances. Consequently, as environmental risks increase vulnerability, they 
in turn decrease resilience. An increase of cooperation and engagement between these stakeholders would not only encourage the spread of important technical knowledge, but also alleviate issues of trust and allow development planners to better the needs of aquaculture practitioners. I believe this is the first step in decreasing vulnerabilities and improving resilience.

In this chapter, I have framed the "side effects" of aquaculture development as environmental risks, to call attention to how programs affect community vulnerability in unexpected ways, particularly in communities that are already vulnerable. This allows space for development planners to re-think how programs work and allow for their improvement. It also provides a frame for evaluating community resilience, which is a big part of contemporary development programs. Unlike James Ferguson who stated that it is "politically naïve" to ask whether or not aid programs can be made to help poor people (Ferguson 1994:180), I believe that it is irresponsible not to. 


\section{Chapter V. Commercial Aquaculture as Post-Disaster Development}

In addition to aquaculture as a general tool for rural development, it also takes the shape of a special type of development, that is, post-disaster recovery following the Indian Ocean tsunami of 2004. My research reveals that the tsunami disaster that affected the coastal areas of Tamil Nadu created an opportunity for greater intensification of aquaculture development strategies in the area. Following the tsunami, development practitioners looked to aquaculture as a method for stimulating the local economy, building upon previous ideologies of the development project. However, as part of the recovery process, aquaculture was also linked to conceptualizations of community resilience. I argue that the utilization of aquaculture livelihoods in this way, connected the aquaculture industry to a new process of development - one that is specifically focused on diversifying livelihoods rather than merely boosting an export economy.

I once again use James Ferguson’s (1994) insights into the “side effects” of development programs; this time, I use his arguments as a way to explain the impacts of the post-tsunami recovery efforts in the Poompuhar area. As I discussed in the previous chapter, Ferguson (1994) found that development programs often expand bureaucratic state power and reframe political obstacles as technical problems best solved by “experts.” I argue that this same process occurred following the Indian Ocean tsunami of 2004, particularly through the ways in which aquaculture research and extension programs spread in the Poompuhar area. The use of aquaculture as an alternative livelihood strategy led to investment in more aquaculture research facilities sponsored by

the government, further strengthening bureaucratic control over the aquaculture industry. 
It also increased the involvement of aquaculture researchers and extension workers throughout the community by addressing community resilience as an issue best solved by technocrats. This served to strengthen the "rule of experts" within the Indian aquaculture industry.

This chapter has three main sections. In the first section, I discuss the immediate effects of the tsunami on Poompuhar, specifically the damage to households, property, and livelihoods. In the second section, I explain the recovery response of NGOs and government organizations following the tsunami. In the third section, I focus on the alternative livelihood programs that involved commercial aquaculture training and discuss why these programs are significant. I assert that these development interventions are significant because they align aquaculture with conceptualizations of community resilience and serve to expand the bureaucratization of the aquaculture industry. I conclude that although the tsunami led to the expansion of the aquaculture development apparatus, that is research institutes and extension programs, it has largely left aquaculture practices in Poompuhar unchanged.

\section{Community Damages from the Tsunami}

On the morning of December 26, 2004, an earthquake with a magnitude of 9.0 occurred off the West coast of Sumatra. The earthquake triggered a tsunami that travelled thousands of miles, hitting many countries throughout the Indian Ocean basin such as India, Sri Lanka, Indonesia, Thailand and Somalia. More than 4500 km of India's eastern coastline were affected up to $3 \mathrm{~km}$ inland, in addition to the country's island territories of Andaman and Nicobar (BEDROC 2009; Thirumalai et al. 2007). Within India, the state 
of Tamil Nadu suffered the most damage and loss of lives. According to my interview with Dr. Lakshmi, a professor in disaster management in India and a key participant in the tsunami recovery efforts, there are several reasons why this is the case. First, she explained that Tamil Nadu has the highest percentage of settlements along the coast compared to other states in India. This means that there were a high number of homes directly hit by the tsunami wave. Second, the location of Tamil Nadu in the Indian Ocean made it particularly vulnerable based on the movement of the tsunami wave. Third, Tamil Nadu has the largest fishery in India, meaning that it has the most production and most fisher folk. This means that many people were on or near the ocean at the time of the disaster (Interview data 2014). Within the state of Tamil Nadu, the Nagapattinam district was one of the hardest hit, as its landmass slightly protrudes into the Bay of Bengal.

The Nagapattinam district encompasses $190 \mathrm{~km}$ of coastline along the Bay of Bengal. It is primarily rural, with fishing as a major occupation. Of the 8,081 people killed in Tamil Nadu during the 2004 tsunami, 6,065 were from Nagapattinam district alone, which is $75 \%$ of the total death toll (Thirumalai et al. 2007). $87 \%$ of the people affected in the district were from fishing communities, while the remainders were agricultural laborers, traders, tourists and religious pilgrims (Thirumalai et al. 2007). Of the people killed within the district, 69\% were women and children (Nagapattinam District 2016). The timing of the disaster may account for this high percentage because it occurred the day after Christmas, which meant that there were many people on holiday enjoying the beaches. It also occurred in the morning, when women often wait on the beach to welcome the fishermen returning from their work on the ocean. The district 
administration called Nagapattinam “Ground Zero" because of the immense destruction in such a small radius.

My interviews with the panchayat office clerk and the Vanagiri panchayat President revealed that within Poompuhar, 224 people died during the tsunami. Additionally, an unknown number of people died in the period after the tsunami from injuries and disease. Vasanthakumar, my translator, described the horror of the days following the tsunami. He told me, "For days after the tsunami, we would find dead bodies floating in the river or washed up in our rice fields. We would collect them and cremate them” (Interview data 2014). Every person I met during my time in Poompuhar had either a friend or a relative who was killed or injured in the tsunami, proving how catastrophic it was for the community. Many others also lost their homes in the flooding. In fact, of the 77 household surveys I conducted, 24 participants reported that they either lost their home or had some damage to their house from the tsunami. Fishermen were particularly affected because their homes were closest to the beach, consequently the whole fishing colony was destroyed in the flooding. They also suffered losses of expensive boats and fishing gear that many could not afford to replace on their own. Of the 77 household surveys I conducted, 11 participants reported that they lost their boat in the tsunami.

Members of the agricultural community and shrimp farmers also spoke to me about the damages they suffered to their land from the flooding. Fields were inundated and filled with muck and debris. The soil quality changed and most farmers reported high levels of salt. Livestock such as goats and cows were killed and farming equipment was 
damaged. The district government reports that nearly 13,000 cattle were killed throughout the district (Nagapattinam District 2016). Even shrimp farmers, who had ponds in operation at the time, reported that their water pumps and engines were destroyed in the flooding. Another major loss was in the cultured shrimp itself because the tsunami occurred during harvest time. Most of the shrimp farms were about to harvest their crops in the next few days, so they lost their entire investment.

In addition to the home and livelihood damage, public infrastructure and facilities were also damaged. Roads were clogged with debris, electricity was disrupted, and drinking wells were contaminated. Within Nagapattinam district, 44 schools, 4 Public Health Centres, and 1 Government Hospital were damaged (Nagapattinam District 2016).

Overall, the damage to the community permeated every aspect of village life, affecting families, infrastructure, and livelihoods. As I will discuss in the next section, there was a swift response from the local and international community to aid in rebuilding. Some people were able to restore their lost homes, property, and businesses, while some have not, even ten years later.

\section{Recovery Responses}

From the perspective of the experts who were involved in coordinating relief efforts, there were various stages of the recovery process. At first, the emphasis was on immediate survival needs and infrastructure replacement (houses, etc.). However, quite quickly, the emphasis moved to improving community resilience. In this section, I will 
discuss these stages with a particular focus on livelihood skill training that became the focus of community resilience programs.

Dr. Lakshmi explained that, “The tsunami response in Tamil Nadu was very interesting and unprecedented because it involved both top-down and bottom-up responses” (Interview data 2014). This is evident in the coordinated efforts that took place in the months following the disaster. Immediately following the tsunami, the Nagapattinam district government took control of relief efforts. The Chief Minister, the head of the district administration, deployed senior officers from different departments such as public health, public works, and the electricity board to oversee the efforts (BEDROC 2009). However, soon after the tsunami, relief personnel and materials came from numerous NGOs and international aid groups, overwhelming the area. There was a need to organize these efforts to insure that the people who needed the help actually got help.

On January 1, 2005 (less than a week after the tsunami) two local NGOs, the South Indian Federation of Fishermen Societies (SIFFS) and the Social Need Education and Human Awareness organization (SNEHA) - both with a history of work with local fishing communities - came together to form a central coordination center. The coordination center, called the NGO Coordination and Resource Centre (NCRC), was a consortium of NGOs that helped organize aid work and served as a liaison between different groups (Interview data 2014). The NCRC created a network through the distribution of laptops and mobile phones amongst aid workers that allowed the consortium to track supplies coming in, determine aid distribution, and give feedback 
about areas of need (Interview data 2014). Overall, at least 500 NGOs registered with the NCRC, which demonstrates the overwhelming amount of support and attention that the disaster attracted (BEDROC 2009). It also highlights the difficult task that the NCRC faced, organizing relief efforts.

The relief efforts organized by the NCRC and in partnership with government agencies, involved several themes. First, there was the distribution of immediate relief materials such as food, cooking fuel, clean water, clothes, and temporary shelter. During my household surveys, people reported that they also received refrigerators (called iceboxes), flashlights, rope, fishing nets, and lifejackets (previously most fishermen did not even own lifejackets according to my interviews).

Then one of the main projects was rebuilding all the homes that were destroyed. Within the Nagapattinam district, 2,169 homes were damaged and 17,461 homes were completely lost in the tsunami (BEDROC 2009). The NCRC collaborated with the state of Tamil Nadu to fund the construction of new homes. Additionally, private companies and international organizations also built homes, such as the Asian Development Bank. Dr. Lakshmi explained that along with the construction of new homes, the government gave certain stipulations to improve the resilience of households and encourage a better quality of life. For example, families were given formal ownership of the land on which their new homes were constructed, which in many cases may have been the first time these families had ever officially owned land. The government also stipulated that the deeds to the homes must be in the husband and wife's names (in the case of a married couple). This presumably was to boost the agency of women within the community and 
ensure that they have a home in the case that their husband dies (to help combat the marginalization of widows, which is a common problem in the area). Additionally, all homes constructed as part of the tsunami recovery were insured for 10 years. The newly constructed homes also had basic amenities such as toilets and septic tanks, which many homes did not have previously.

The majority of these newly constructed homes went to fishing households because they experienced most of the damage (Interview data 2014). However, subsequent community surveys conducted by NGOs coupled with complaints from villagers, demonstrated that other families had lost their homes and deserved compensation. Therefore, a few non-fishing families also received new homes in the months following the tsunami. Ten years following the tsunami, this is still a point of contention in the village, as some people believe that the fishing households received unfair aid. These complaints come from farming households, many of which are still living in unstable mud-brick and thatch homes, while fishermen were given larger and nicer cement block homes. It is understandable that such a situation would create animosity and jealousy within the village.

In addition to new homes, fishermen that lost their boats in the tsunami also received government loans to buy new boats. Farming households received gypsum and lime to help restore the correct $\mathrm{pH}$ in their soils from the Madurai based NGO, Covenant Centre for Development (CCD). There was also some compensation from the government for loss of family members, in place of life insurance, which most people did not have. Over 4,000 legal heirs received financial assistance of Rs. 1.00 lakh from the 
Chief Minister’s Relief Fund and the Prime Minister’s Public Relief Fund (Nagapattinam District 2016).

Another recovery priority organized by the NCRC was damage assessment. Surveyors measured and mapped the vulnerabilities of community members in order to create a plan to improve resilience. For example, NCRC workers collected information about the needs of small farm operators versus large farm operators, what types of things they were at risk for, and what resources would help them. Surveyors found that water regulator equipment on the Cauvery River needed maintenance and that drainage canals needed desilting. They carried out these improvements with the help of the community as a way to proactively prepare for any future environmental disaster (Interview data 2014).

The first two stages of the recovery process illustrate an important point, that is, that communication and collaboration between people in the village and development professionals/disaster recovery experts was productive and successful. The examples I discussed show how groups of people worked together and the needs of the community became the number one priority. Villagers were able to see measureable benefits to their community, through the rebuilding of homes and distribution of food, and consequently they allowed development experts into their lives. As I have discussed in previous chapters, this type of participatory process is not characteristic of traditional development strategies but it seems that such a tragic event really galvanized development workers and brought them closer to the community. Unfortunately, as later phases of the recovery unfolded, some of this collaboration fell apart - particularly in instances of sill training, which I will discuss next. 
The final strategy of recovery that the NCRC implemented was skill training. After the recovery efforts met the immediate survival needs of people following the tsunami, such as housing, food and drinking water, another major problem emerged; the local economy of rural villages, traditionally based on fishing and farming, was severely damaged. One fisherman in Poompuhar explained, "After the tsunami I had nothing. My boat was gone. My nets were gone. I had no way to earn a living” (Interview data 2014). Additionally, many farmers, including shrimp farmers in Poompuhar, suffered tremendous financial losses because the tsunami hit at harvest time. Kaliyaparumal, a shrimp farm owner with ten years of aquaculture experience in Poompuhar, told me that he lost Rs. 10 lakhs because the tsunami ruined his whole shrimp harvest. That amount is equivalent to almost US\$20,000.

The NCRC and local government decided to implement skill training and alternative livelihood programs to provide more jobs and strengthen the resilience of local communities like Poompuhar. These ideas were based on disaster theory that posits that one way to protect communities particularly vulnerable to natural disasters and environmental changes, is to make them more resilient through diversification of livelihood opportunities (Blaikie et al. 1994). That way, people do not depend on only one main industry for income, which can be particularly risky. If numerous industries contribute to the local economy, it may be able to withstand sudden fluctuations. This theory is similar to the idea of crop diversification in agriculture to protect against instances of disease. 
The community resilience approach is not unique to the case of Poompuhar or other post-disaster development instances however. This discourse follows trends within the broader international development sector, where resilience has become a common “buzzword” and favored metric of progress (Barret and Constas 2014; Gaillard 2010). Development professionals have gravitated towards resilience as a concept because it provides the possibility for a quantifiable framework - for example, creating " $X$ " number of different types of jobs. It is also a holistic concept that integrates a variety of social factors, which is attractive in an age where people are becoming more aware of the complex entanglements of our society. Scholars have also provided evidence that it can be successful. For example, Pant et al. (2012) investigated the impact of integrated agriculture-aquaculture farming systems on community resilience in Nepal. They found that households that diversified their livelihood practices with aquaculture were more likely to have the capacity to overcome ecological, social and economic disturbances/fluctuations, consequently improving overall resilience.

Following this theory, the government of Tamil Nadu and NGOs invested funding and support for "alternative livelihood options" for fisher folk so that they would have different skills and means of making an income (Interview data 2014). Development practitioners specifically targeted fisher folk for this program because they were one of the hardest hit populations in Tamil Nadu. Additionally, fishing communities already had a history of poverty and vulnerability (Interview data 2014). Dr. Lakshmi also explained that women were given special consideration in these programs because historically, they have less employment opportunities. 
My interview with Santosh B., one of the employees of a local NGO that was one of the leading organizations spearheading the post-tsunami recovery, revealed that technicians introduced many alternative livelihood opportunities. Trades such as fish processing, tailoring, basket weaving, and dairying were among the many options (Interview data 2014). Some programs were successful, particularly skills related to fish processing, but many failed to be sustainable or profitable. For example, according to Dr. Lakshmi, a shoe store was only kept open when the district collector came to visit. Santosh explained that one of the main reasons that programs failed is that they did not rely on the traditional livelihood skills that already existed in the communities. In some cases, they introduced trades that were foreign to the village and thus were too difficult to practice or unwanted by villagers. My interviews with community members also revealed that livelihood techniques are deeply ingrained in people and tied to important factors such as caste and gender. Susie, a fisherwoman in Poompuhar explained to me, "We are fishing folk. All we know how to do is fish. If you tell us to do something else, we won't do it. We will only fish” (Interview data 2014). This quote explains how people, particularly fisher folk, can resist efforts to learn new trades because their livelihood is tied up with their very identity. Susie's husband is a fishermen in the village and she is part of a SHG in Poompuhar that was trained by the M.S. Swaminathan Foundation Fish For All Centre to make fish pickle for sale in local markets. Development workers refer to this approach as "adding value" to fish products. The problem is that thus far, the women's SHG had yet to profit from their new skill. They were only breaking even in production costs. Instead, they found that they made more money catering lunches for visiting research groups at the local research center. 
The cases of failed livelihood training programs provide another example of the "rule of experts," as previously discussed in other chapters. It illustrates how there is a lack of understanding and communication between development workers and villagers. This results in the needs and desires of the community being ignored or misinterpreted, while the initiatives of the development workers take precedent.

Aquaculture training was also a major part of alternative livelihood programs following the tsunami. In the following section, I will discuss this process and how it was important in linking aquaculture with conceptualizations of resilience, which I argue, reinvigorated or rebranded rural development strategies. I will also discuss how this led to the expansion of aquaculture research and development throughout the region, a significant outcome of the tsunami.

\section{Aquaculture as Post-Disaster Development}

Aquaculture training was another aspect of the alternative livelihood programs promoted after the tsunami. Such training was sponsored by the state Fisheries Department and two local research centers constructed in Nagapattinam district, Rajiv Gandhi Centre for Aquaculture (RGCA) and (M.S. Swaminathan Research Foundation (MSSRF) Fish for All Centre. The RGCA facility is located a few kilometers outside of Poompuhar and is part of the research subsidiary of MPEDA, meaning that it is funded by the central government. The MSSRF Fish for All Centre is located in Poompuhar itself, near the beach and is funded by the M.S. Swaminathan Research Foundation, which is a non-profit trust. An important point to note is that these two research centers did not exist prior to the tsunami. It was only a result of all the recovery funding and 
programming that they were constructed to support the livelihood training programs. In fact, the Poompuhar Panchayat President at the time of the tsunami, Ms. Manimekhalai, donated part of the land for the construction of the MSSRF Fish For All Centre.

The aquaculture programs developed after the tsunami consisted of demonstration farms, training sessions, and SHG funding; all geared towards encouraging people in the area to take up different types of aquaculture practices. In particular, both the RGCA and MSSRF Fish for All Centre promote alternatives to shrimp farming that researchers believe are more environmentally and economically sustainable. For example, the RGCA has a mud crab demonstration farm in Karaikal, approximately $37 \mathrm{~km}$ south of Poompuhar. It also is in the process of establishing a demonstration farm in Tamil Nadu for raising brine shrimp, which are valuable as feed in the aquaculture industry. Additionally, the MSSRF Fish for All Centre has funded and organized two women's SHGs in the Poompuhar area for freshwater fish farming.

These aquaculture programs are significant in two main ways. First, they mark a re-branding of aquaculture development programs in India, linking initiatives with conceptualizations of resilience. As I have discussed in the previous chapter, commercial aquaculture expansion has been closely linked with development ideologies that have traditionally focused on food security and economic gains. However, following the tsunami, this development discourse in India has expanded to include ideas from disaster and risk management. For example, the MSSRF Fish For All Centre informational brochure states that the Centre was 
conceptualised in response to the felt need of the coastal communities

along the Tamil Nadu coast to bring about a collective and a holistic approach for the coastal community in the field of resource management, sustainable livelihood options and for disaster preparedness and management (MSSRF).

This quote clearly highlights the alignment between aquaculture and disaster management, and fits into conceptualizations of resilience that hinge upon changes to livelihood practices, specifically through the mention of "sustainable livelihood options."

The reason that this linkage between aquaculture development and resilience in India is important is because it recognizes new ways in which such practices can be beneficial to communities. This suggests that due to increasing community vulnerabilities to natural disasters from climate change, aquaculture may be incorporated into more development programs throughout the country. It also demonstrates that development workers are trying to find a way to measure community well-being and progress that synthesizes social, economic, and environmental factors.

The second reason that the post-disaster aquaculture programs are significant is because they led to the expansion of aquaculture research and extension not only in Poompuhar, but also throughout India. For example, during my fieldwork in 2014, the RGCA had nine ongoing projects to develop new aquaculture technologies in India such as a mud crab hatchery and seabass cage culture (Interview data 2014). They also have 11 different facilities spread throughout South and East India where they carry out 
experiments and public demonstrations (See Figure 8).

\section{RGCA Project Locations}

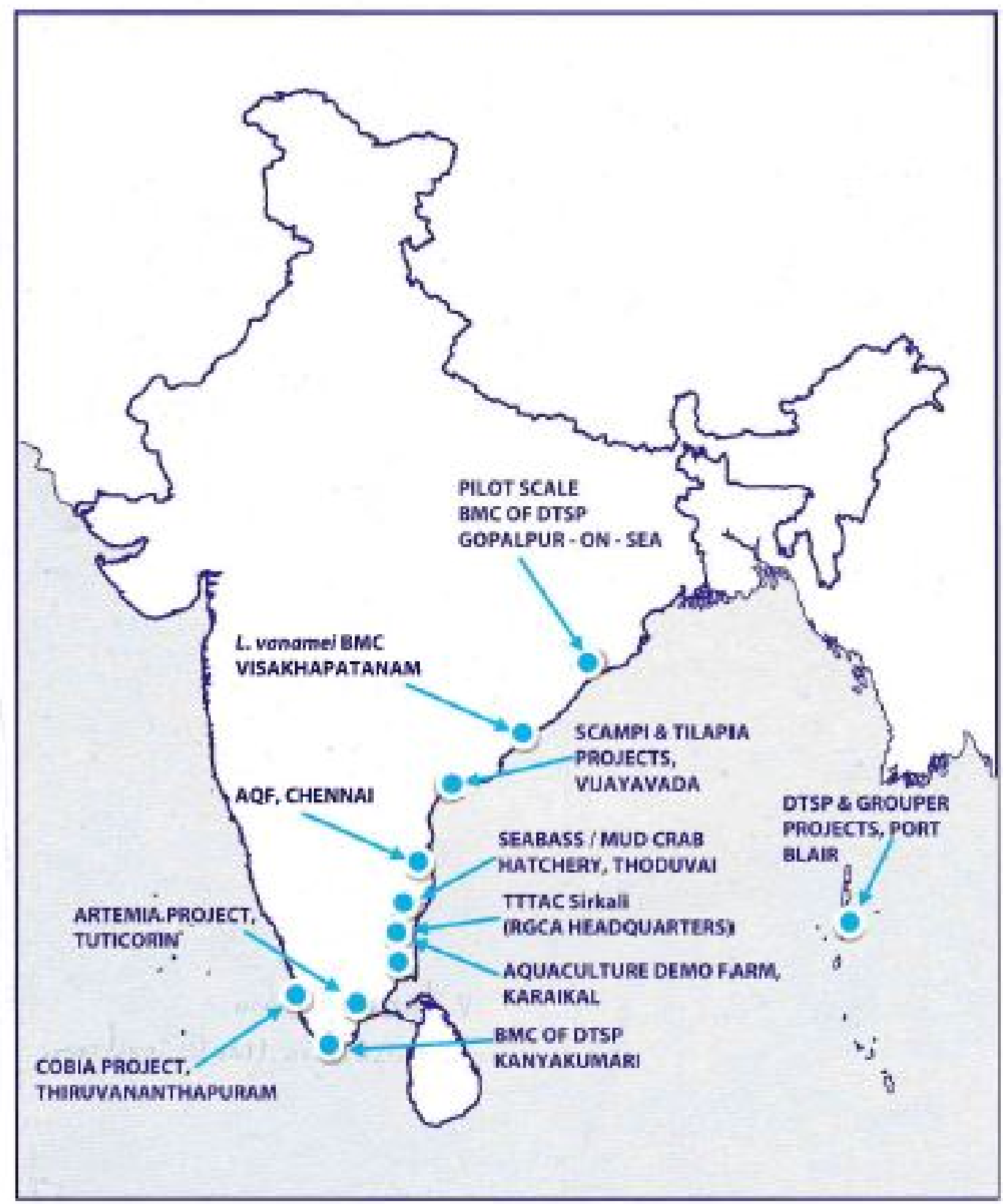

Figure 8. Locations of RGCA Projects in 2014 (map created by RGCA) 
This demonstrates that these institutes have extended the reach of aquaculture development throughout India, well beyond Poompuhar. Now "RGCA" and "MSSRF" are synonymous with aquaculture development in the area. When I went on interviews in Nagapattinam district and mentioned that I was affiliated with MSSRF (because they were hosting my fieldwork), people already knew what type of research I was doing.

These findings suggest that the tsunami created an opportunity for the intensification of aquaculture development programs and public awareness of various aquaculture practices throughout India. The spread of state sponsored aquaculture research programs also demonstrates how post-tsunami development led to the expansion of government involvement throughout the community, aligning with Ferguson's (1994) arguments that development leads to bureaucratization.

However, it is important to note that although the tsunami has led to the expansion of aquaculture development programs and possibly public awareness of aquaculture through the increased number of training programs, actual aquaculture practices within Poompuhar have not really changed since the tsunami. My interviews with community members revealed that before the tsunami, the main aquaculture practice taking place in the village was shrimp farming, and after the tsunami that fact has not changed. Although the development workers have promoted alternatives to shrimp farming, these practices have not caught on in the village. The number of shrimp farms in Poompuhar did increase though after the tsunami, which is partially because people transitioned to shrimp farming because their agricultural land was salinized from the tsunami (and other environmental changes that I discuss). 
What has changed for the aquaculture practitioners in Poompuhar is their access to water quality monitoring and consulting services, both of which RGCA provides. Before the tsunami, shrimp farmers could not monitor levels of bacteria or nutrients within their shrimp ponds unless they had lab equipment of their own, which was highly unlikely. The RGCA facility outside of Poompuhar includes a state-of-the-art laboratory where shrimp farmers can now send water samples and shrimp to be analyzed for a fee. This increases the capacity for better management practices within Poompuhar. It is important to note however, that because these services cost a significant fee, many of the shrimp farmers do not make use of the services or at least not on a regular basis. The RGCA facility also contributes to the production of specific pathogen free (SPF) lines of shrimp stock that undergo rigorous bio-monitoring and quarantining procedures in order to provide farmers with seed that is free of disease. These SPF stocks are not inherently immune to disease, but they do improve quality control and reduce the amount of disease outbreaks within shrimp farms in the area. So overall, the RGCA has improved overall shrimp aquaculture management, although more improvements could be made.

\section{Conclusion}

The Indian Ocean tsunami of 2004 significantly affected the state of Tamil Nadu, particularly the village of Poompuhar. The majority of people affected were in poor, rural areas that had little preparation to deal with such a tragedy. Fortunately, the local community, government and international groups came together and aided in the region's recovery. The recovery efforts hinged upon resilience building, particularly livelihood diversification. A major part of alternative livelihood programs promoted as recovery 
efforts was that of commercial aquaculture training. In this way, aquaculture was used as a type of rural development strategy in the post-disaster context.

In the wake of these programs, more aquaculture research and extension facilities were built, there was more funding for aquaculture development, and more awareness spread throughout the region about aquaculture techniques. However, rather than actually creating more varied professions within the community, my findings demonstrate that these interventions actually left livelihoods, specifically aquaculture practices, largely unchanged. Community members may be more aware that alternatives to shrimp aquaculture exist, but that awareness has not translated into much interest in those alternatives or actually changed aquaculture practices. What resulted was an expansion of the bureaucratization of aquaculture development and a strengthening of the rule of experts in the aquaculture industry. 


\section{CHAPTER VI. THE AQUACULTURE TRANSITION AND THE GLOBAL INTIMATE: UNDERSTANDING AGRARIAN CHANGE IN THE WAKE OF COMMERCIAL SHRIMP AQUACULTURE}

Studies have shown the connection between shrimp aquaculture and changes in agrarian structure (Islam 2014; Ito 2002; Saguin 2015). For example, researchers document that shrimp aquaculture affects labor, income, and land tenure (Islam 2014). A large body of literature has also focused on one particular aspect of what can be termed, the "aquaculture transition," that is, the globalization of aquaculture through the analysis of aquaculture products as an export commodity (Belton and Little 2008; Bush and Marschke 2014). However, there is a need for more discussion regarding connections between the aquaculture industry and other regional and global networks. I argue that the commercial aquaculture industry in India, through processes of agrarian change, is embedded in multiple extralocal networks of materials, scientific knowledge, labor and risk. Highlighting these complex networks helps scholars to understand the socioeconomic impacts of aquaculture on multiple scales.

My analysis builds upon the theoretical framework of the "global intimate," a concept that feminist geographers such as Geraldine Pratt and Victoria Rosner (2006) and Alison Mountz and Jennifer Hyndman (2006) used to understand the multiscalar interactions that take place through globalization, particularly social relations that often go un-noticed. Mountz and Hyndman conceptualize the "intimate" as "embodied social relations that include mobility, emotions, materiality, belonging, alienation” (2006: 447). In this way, the "intimate" is a concept that is more descriptive than the "local;" it encompasses the home, the body, and more abstract categories such as ways of knowing 
and vulnerability. Mountz and Hyndman argue that the intimate and global constitute one another, rather than occupying "separate spheres” (2006: 448). In other words, it is a way of looking at multiple scales simultaneously as well as analyzing how everyday processes in the home, community, and region are shaped, and in turn shape, global processes. Consequently, the global intimate is a different way to interrogate processes of globalization, challenging the traditional dichotomy of global and local scales as well as highlighting the impacts globalization has at a more personal level, particularly within the household.

Thus far, scholars have contributed to the global intimate literature in a variety of ways to interrogate the processes and impacts of globalization. For example, Cindi Katz (2001) investigated the socio-economic changes in a village in Sudan following the application of a rural development project called the Suki Agricultural Project. Katz found that the project, which intended to boost Sudan's export economy, led to significant gendered changes in employment, education, land tenure, and access to natural resources. Changes in the local economy resulted in the migration of young men out of the village, leaving women and children to carry out much of the agricultural responsibilities. My research contributes to analyses like Katz’s by exploring how development programs, entangled in processes of globalization, have affected gendered relations.

Additional studies contribute to the global intimate literature by drawing attention to intimate scales of analysis such as the body, emotion, and sexuality. For example, Min Jin Lee (2012) studies inter-cultural discourses and perceptions of interracial love, which 
allows her to interrogate racial stereotypes in a global context. Andrea Wood (2006) studies the production and consumption of queer themed manga and how the transnational circulation of such materials has the potential to subvert sexual norms across cultures. Both of these studies underscore the point that globalization affects us on many different levels, sometimes in ways that are less visible to others. Building upon this point, as I began to analyze the effects that the commercial aquaculture industry has had on Poompuhar's agrarian structure, I realized that these transitions involved flows of more than just money and shrimp - things that are less noticeable or more difficult to measure, such as flows of knowledge and risk. I took inspiration from the global intimate literature to analyze these flows. In this chapter, I demonstrate how networks of materials, knowledge, and risk connect the village of Poompuhar to neighboring districts and states, as well as to China and the United States. I also discuss how the aquaculture transition in Poompuhar affects the more intimate aspects of the village, such as food security, social stratification and gendered labor. My analysis consequently contributes to discussions of agrarian change by linking it to the global intimate.

The chapter has three main sections. In the first part of the chapter, I describe how the aquaculture transition is taking place and the motivations behind it. In the second section, I explain the various changes taking place due to the emergence of shrimp aquaculture, such as the intensification of cash cropping, different resource use, and gendered division of labor. In the third part of the chapter, I demonstrate how shrimp farming involves wider connections to extralocal networks of materials, scientific knowledge, and labor. 


\section{Motivations Behind the Aquaculture Transition}

The aquaculture transition taking place in Poompuhar is largely due to the spread of shrimp farming, which dominates aquaculture production in the area. Satellite photos from 2003, 2011, and 2015, available in Google Earth, serve as visual documentation of the spread of these shrimp farms over the last 13 years (See Figure 9). The top photograph is from May 2003, the middle photograph is from July 2011, and the bottom photograph is from June 2015. Shrimp ponds are marked in red. Between each of the photographs, there is a gradual change in the color and border of different land plots, which shows the transition from agriculture to aquaculture. Specifically, the plots that changed from a mottled/light green to a solid/darker green, surrounded with a thicker dirt border are evidence of a transition from rice or pasture to a water filled shrimp pond. In some cases, a plot changes from green to a sandy, whitish brown color, which is evidence that a shrimp pond has either recently been constructed or is in between harvests. Other clues in these photographs that point to a transition to aquaculture, are the presence of aerators, small jetties, and sluice gates within the plots of land. In these photographs, you can see that approximately 49 shrimp ponds had been developed by May 2003. As of July 2011, there were 69 ponds, and as of June 2015, there were 94 ponds. It is unclear in these images, which ponds are actively in use, as some ponds may have been abandoned over time but still visible. However, it does strongly suggest there is an increase in shrimp farm development over the past 12 years. Survey data also corroborates the trend of increasing numbers of shrimp farming activity, as I discussed in the previous chapter. 

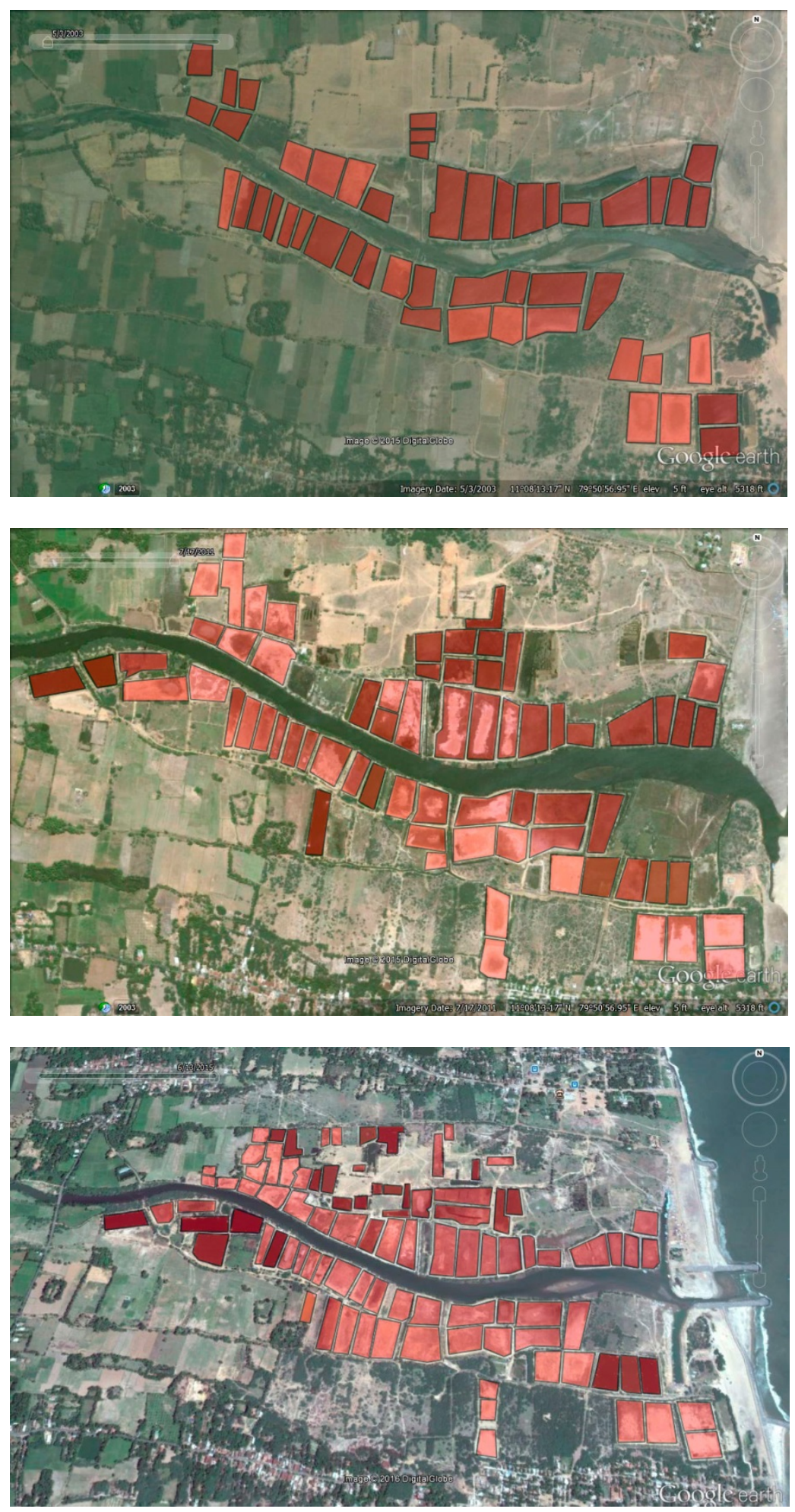

Figure 9. Satellite Images of Shrimp Ponds in Poompuhar 
In the previous chapters, I examined some of the reasons that motivate people to transition livelihood techniques from agriculture to shrimp farming, particularly changes to the local environment. Here, I analyze this topic in more detail. According to my interviews, there are two main driving forces behind why people choose to convert to aquaculture: 1) economics, and 2) a feeling of "last resort". I argue that both forces are linked to risk. In the case of economics, shrimp farmers risk financial instability in order to "hit the jackpot." Alternatively, the feeling of last resort is a result of villagers victimized by the externalities of aquaculture, forcing them into the industry. In other words, current shrimp farmers pass on the risk of the shrimp industry to others in their community. This cycle of risk is what Mountz and Hyndman (2006) would consider an intimate social relation, one that has gone unremarked by other scholars.

Shrimp farming is considered a risky business venture by aquaculture managers and even some farmers I interviewed, because there have been several major occurrences of local market crashes due to disease outbreaks in shrimp stock. Karthik, a shrimp farmer in Poompuhar explained, "The [shrimp farming] industry is like the lottery - it's not all in our control. One farmer makes a mistake and it affects everyone.” In this quote, Karthik refers to the problem of disease spreading rapidly between shrimp farms if the workers practice poor management, such as over-stocking ponds or not monitoring water quality. Additionally, Dr. J. Raj, a professor involved in aquaculture research and development at a local fisheries college told me, “We don’t want the farmers to gamble. We want something more reliable for livelihood security, that's why we're moving away from shrimp and to fish” (Interview data 2012). Dr. J. Raj was referring to efforts to 
promote fish farming instead of shrimp, an endeavor that has been going on throughout India for decades. The experience of shrimp farmers in Poompuhar demonstrates why extension workers like Dr. J. Raj want local people to abandon shrimp aquaculture. Half of the shrimp farmers I interviewed complained to me about problems with disease outbreaks in their ponds, and at the time of my study, several farms were experiencing an outbreak of White Spot Syndrome, a virus that leads to high mortality rates in the shrimp stock. Disease outbreaks are so detrimental to shrimp farmers because they can kill an entire stock in a matter of days. Outbreaks also decrease growth rates, leading to lower market values, and White Spot Syndrome in particular is highly contagious. This means that the virus can quickly spread from one pond to another, and even between other shrimp farms through vectors such as birds (picking up shrimp from one pond and dropping it in another pond), and mud crabs. Diseases can also spread through water from farms discharging contaminated water into drainage canals connecting multiple farms. RGCA and the CAA urge farmers to notify managers and each other through a text message system if there is a disease outbreak in their stock, so that they can take precautions and stop the spread of disease. However, an extension worker told me that shrimp farmers often do not notify others if they have disease problems because they are ashamed.

The volatility of the shrimp market is also evidenced in the shrimp farm data collected by the M.S. Swaminathan Research Foundation Fish for All Centre in 2009, which reports that 11 out of 17 shrimp farmers had a negative net income that year from their harvests. These negative profits are attributed to disease outbreaks and high 
operation costs, such as the cost of shrimp seed, feed, and electricity. The 2009 data shows that the average operation cost of one shrimp pond (at the time) was 285,303 rupees a year, approximately U.S. \$5,706. The majority of these operating costs were from the feed inputs. Meanwhile, the average income from one shrimp pond was 273,275 rupees a year, approximately U.S. \$5,466. That is an average deficit of 12,028 rupees a year. This deficit may seem small, but in an economy where the average daily income of a laborer is approximately 450 rupees, it is quite significant. On the other hand, during the same year, the data shows that one shrimp farmer was able to profit 934,950 rupees, approximately U.S. $\$ 18,699$. This demonstrates the unpredictability of the local cultured shrimp market.

Despite these risks however, shrimp aquaculture is still viewed as a way to "get rich quick” by local villagers, especially compared to rice farming (Interview data 2014). The reason for this is due to the incredible difference between what a farmer can make per kilogram of rice (and other agricultural crops) versus shrimp. During my data collection, farmers were receiving only 17 rupees $/ 1 \mathrm{~kg}$ for rice, 50 rupees/ $1 \mathrm{~kg}$ for cotton, and 20 rupees/ 1kg for groundnut. In sharp contrast, they received between 450-620 rupees $/ 1 \mathrm{~kg}$ for cultured shrimp (Interview data 2014). That means that cultured shrimp fetches up to 36 times the price of rice, creating a strong incentive to make the transition to shrimp. Other studies corroborate this data, reporting that the average yearly income of a rice farmer is approximately US\$ 4,000, compared to US\$60,000 for a shrimp farmer (Flaherty et al. 2009). This means that a shrimp farmer can typically suffer several years of loss and still support their household after only one profitable harvest. The large profit 
margins for cultured shrimp also mean that farmers can recoup their start-up investment, estimated at 1,000,000 Rs. (US\$20,000), in only a year or two (Flaherty et al. 2009); the main barrier being access to initial financing.

Besides larger profit margins, the other reason that people transition from agriculture to aquaculture is what I describe as a "last resort," or what I have briefly discussed in the previous chapter as a sense of inevitability. Some lands have suffered such high levels of salinization (either from the tsunami or adjacent shrimp farming) that the owners can no longer farm any other crop or productivity has severely flagged. In those cases, the owners felt that shrimp farming was a good option because high salt levels in the soil and water are not a problem for such practices. I describe this driving force as that of a "last resort" because to these people shrimp farming was not their desired profession. In some cases, these landowners know that they are probably contributing to further salinization of the land but they feel that they have to go along with it or risk suffering unemployment and poverty. Due to the difficulty of growing crops on the salinized soils, the only alternative would often be to let the land sit vacant and unused.

My translator, Vasanthakumar, is an example of this kind of thinking. He has a background in environmental studies and years of experience conducting water quality samples as an environmental contractor. He explained to me that he has seen how shrimp farming can be harmful to the environment and on many occasions, he complained about how shrimp farmers as well as managers do not seem to care about the impacts of the industry. However, despite his negative impressions of the industry, Vasanthakumar was 
hoping to get enough money together to eventually start a shrimp farm of his own, because he felt it was the only way for his family to make a profit from their land. Currently, his father is farming rice and cotton, but merely breaking even on his endeavors. Vasanthakumar explained to me, "My father is only farming because that's what he likes to do and what he knows. It's not for the money. He isn't making any money from it.” I asked him if he and his two brothers would try to farm their family land if his father passed away. He said he didn’t think so. Vasanthakumar's family is an example of a family on the cusp of transition, torn between tradition and a longing for progress. Being the oldest son, Vasanthakumar feels a lot of pressure to provide for his family, especially in the future when his parents are too old to work. Therefore, he is willing to pursue a livelihood he does not agree with if it means he can improve the wellbeing of his family.

Another villager who represents an instance of turning to aquaculture as a last resort is Ramakrishnan, a shrimp farmer who is now in his 70s. The story of how he entered the shrimp farming business clearly illustrates the social and political tensions entangled with the aquaculture transition. He explained,

About 15 years ago, the first aquaculture farm entered the area next to my farm land. There were seepage problems from the shrimp farm. I wrote a letter to the district collector complaining. The collector came to see, but the pond owner's money and political influence swayed the collector. So I decided I would open a [shrimp] pond, too (Interview data 2014).

Like Vasanthakumar, Ramakrishnan’s first choice was not to join the shrimp farming industry. Only after other avenues had failed, did he decide to make the transition, reminiscent of the adage, "If you can't beat them, join them.” 
Other studies report similar agrarian shifts from rice paddy to shrimp farming, such as Sanae Ito's research on freshwater prawn cultivation in southwestern Bangladesh (Ito 2002). Similarly, Ito reported that the driving force behind this transition is the high market value of shrimp. Additionally, Flaherty and others' research in Orissa, India (2009) found that the majority of people switched to shrimp farming from rice paddy following the "Super Cyclone" of 1999. Like the salinization problem in Poompuhar, villagers in Orissa turned to aquaculture when their fields became too saline to produce rice due to extreme coastal flooding. Flaherty et al. refers to this process as a “compulsion” to transition to shrimp farming, reminiscent of Poompuhar's situation of last resort. Deb’s (1998) research regarding the impacts of shrimp farming in southwest Bangladesh also uncovered similar impacts. He argues that villagers choose to take up shrimp farming despite knowing that it will have harmful environmental impacts on their community because they are trying to do what is best for their families. Deb refers to this process as "deliberate blindness." These research findings underscore the point that shrimp farming as a livelihood strategy is often not the first choice for villagers yet poverty and environmental change drive them to the aquaculture transition.

\section{The Aquaculture Transition vs. Traditional Agriculture}

The transition to cultured shrimp involves several significant departures from traditional agricultural practices and structures in Poompuhar. I have discussed some of these changes in the previous chapters, but in this section, I go into more detail about how the aquaculture transition compares to traditional agricultural practices. In some ways, these changes follow the formula of an agrarian transition, where there is a shift from 
small-scale subsistence farming to a capitalist mode of production (Bernstein and Byres 2001; Saguin 2015). It will become evident that these changes involve various aspects of both the global and the intimate.

\section{Intensification of Cash-cropping}

Although farmers were already engaged in the market economy by producing one or two "cash crops" that they would rotate depending on the season, such as rice or cotton, there was still some level of subsistence farming taking place. Small corners of their land would be used to grow vegetables and lentils, or to graze cattle and goats that would provide milk and/or meat for the household. Many farmers are still following this agrarian approach, but those who have made the transition to shrimp aquaculture are not. The switch to shrimp aquaculture effectively ends subsistence practices on plots of land because all the space is used to maximize pond area in an effort to get "more bang for the buck.” As I will discuss further in a later section, this change may reduce food security because households are producing less food for themselves, making them completely dependent on local markets. However, this is often a necessary approach in shrimp farming because the initial start-up cost and operation costs are so high, that in order to profit, shrimp farmers must have high yields. Consequently, the aquaculture transition involves an intensification of cash cropping and the entrance of monoculture farming, where shrimp is the sole "cash crop" and the land sits dormant in between harvests of shrimp.

As I discussed in a previous chapter, monoculture farming introduces additional types of risk due to problems with disease outbreaks within the stock. For example, if a 
pond solely stocked with $L$. vannamei suffers a viral infection, the entire stock in the pond will most likely perish, resulting in a total loss for the farmer. This is a well-known occurrence amongst shrimp farmers (Interview data 2014). Alternatively, if the pond was stocked with a variety of aquatic species, otherwise known as "polyculture," a viral infection is less likely to lead to a complete loss because not every species would be susceptible. Therefore, polyculture can be less risky for practitioners. However, in Poompuhar, and even the wider district, shrimp polyculture practices have not caught on with practitioners. Of the 49 aquaculture farms I surveyed, only 8 practiced polyculture (3 within Poompuhar) and none of them included shrimp - they were all freshwater fish farms that raised various species of fish in the same ponds. My interviews with shrimp farmers suggested that the reason shrimp polyculture is not locally popular is due to the perception that it takes more work and special knowledge.

\section{Introduction of an Export Commodity}

Another major departure from traditional agricultural practices in Poompuhar is the production of an export commodity. In the case of other agricultural items such as rice and cotton, they are sold in local markets or other areas of India. Rice farmers also explained to me that the government of India buys a lot of the rice that is produced and then redistributes it through ration programs. However, as I explained in the previous chapter, cultured shrimp is exported out of India to countries such as Japan and the United States. Very rarely do shrimp farmers or other households consume farm-raised shrimp because it is too expensive, costing one person's entire daily wages per kilogram of shrimp (Interview data 2014). I found during my field research that only wealthy 
families in the village consumed shrimp, and even then, the shrimp was small meaning that it was cheaper than export quality. This is not a trend unique to Poompuhar, or even India, as cultured shrimp is primarily an export commodity worldwide (Rivera-Ferre 2009; Stonich et al. 1997). Interestingly enough, one shrimp farmer asked me if it is true that Americans eat shrimp every day, just as many Indians eat rice. He was under this impression because of the amount of shrimp exported to the U.S. He figured with so much demand for shrimp it must be a daily staple in the American diet. He was surprised when I told him that it was not the case. This anecdote is a prime example of how the transition to an export commodity distances the producer from the consumer, so that the farmer does not know who is eating their food (and in the case of Americans, anecdotal evidence suggests that the consumer does not know where it is coming from).

The result of this transition from locally sold cash crop to exported cash crop is that shrimp farm owners are now affected by the global economy rather than just the local economy. This means that it can be more difficult for farm owners to predict market trends or estimate how much profit they will make. It also means that they are exposed to more financial risk. For example, India’s seafood export declined between 2001 and 2002, a loss of 486.84 Rs. crore (US\$ 4868.4 million), this coincided with the U.S.'s recession in 2001 that lasted 8 months. During this time, the value of shrimp also declined (Flaherty et al. 2009). There was another decline in cultured shrimp exports to Europe and Japan in 2004 due to antibiotic residue found in quality control samples (Flaherty et al. 2009). One shrimp farmer in Poompuhar, Karthik, also mentioned in an interview with me that the Indian cultured shrimp market is heavily dependent on China's 
shrimp market. This is because China is the world's leading producer of cultured shrimp. Karthik explained that if it were not for China, Indians would be getting much more for their cultured shrimp because China is flooding the market. According to him, China is also able to drive the price of shrimp down because they have cheaper operating and labor costs. Karthik explained, "In China they have more of a family business which minimizes the labor cost.” He is referring to the fact that shrimp farms in Poompuhar rely more on non-family labor, perhaps due to cultural customs that deter women from participating (as discussed in another section). Instead of keeping profits within the family, shrimp farm owners must pay outside workers. In 2015, The MPEDA created two mobile applications ("apps”) to help mitigate the financial risk of the global shrimp market (The Hindu 2015). The first, called m-KRISHI Aqua Service, provides farmers with guidance regarding management practices based on weather trends, type of feed used, and productivity. The second is a set of numbers that farmers can call to receive market updates about current pricing trends for both P. monodon and L. vannamei. These examples show the complicated mix of factors that shrimp farmers need to consider when planning their harvests. They need to balance the trends and demands of global markets with intimate knowledge of local labor practices and consumption preferences. In this way, shrimp farmers engage with the global intimate themselves.

\section{Food Security}

The transition to an export commodity also affects another intimate aspect of local households, that is, food security. Because cultured shrimp are not locally consumed, production does not improve local household's access to protein as development 
programs hoped. Additionally, because shrimp farming is only practiced by middle-upper class members of the community and does not require many additional laborers, the profits from shrimp farming do not reach most of the village. In many cases it seems to be hurting the household incomes of people who traditionally participated in rice and cotton farming as hired laborers, because the transition to aquaculture has limited their employment opportunities. Consequently, households from a lower socioeconomic class would have less money to purchase sources of protein.

However, other products involved in the aquaculture transition do improve availability of protein. Cultured freshwater fish (the only other cultured product produced in Poompuhar at the time of this project) has a very different pattern of marketing and consumption. Freshwater fish such as carp are stocked and raised in small ponds, often on agricultural land. Villagers sell the fish live in local markets or keep them for personal consumption. Carp farmers explained to me that people from the surrounding villages buy their fish particularly on weekends, holidays, and other special occasions such as a wedding. Freshwater fish are affordable for the average household to purchase at least once a week, thus contributing to local food security. From my discussions with researchers and aquaculture extension workers, I gathered that they believe that shrimp farming does not contribute to food security, while alternative practices such as fish aquaculture hold more promise. That is one of the reasons why they encourage other types of aquaculture instead of shrimp. 


\section{Increased Inputs}

Shrimp aquaculture also involves many more inputs than traditional agriculture. First, it requires much more water because whole hectare plots must be inundated with 3 feet of water. In the case of Poompuhar, the water for shrimp ponds is pumped from ground water resources using bore wells and supplemented with river water. This means that shrimp farmers must compete for water with other users, particularly in times of drought. Second, the shrimp farms in Poompuhar rely on specialized machinery such as pond aerators, water pumps, and feed dispersal units. This contrasts to rice or cotton, which many farmers in Poompuhar grow without the use of any machinery. Third, shrimp farmers utilize more chemical and mineral inputs than other crops. The shrimp farmers in Poompuhar add lime, dolomite, calcium, bleach (before the shrimp are added to kill pest contaminants), probiotics, and vitamins. The complexity of these inputs contrasts starkly with rice and cotton farms, which mainly rely on pesticides, when needed, without all of the other inputs. Lastly, shrimp farms in Poompuhar use more electricity and fuel to power all the machinery, which according to my interviews is a major production cost. The increase in inputs, especially the mechanization of practices, is another similarity between the shift to shrimp aquaculture and traditional agrarian transitions.

\section{Employment}

Another major change associated with the aquaculture transition in Poompuhar is employment. As I previously mentioned, development planners envision aquaculture as a job creator, alleviating high rates of unemployment that plague rural villages in places 
like Poompuhar. However, my interviews and surveys suggest that agriculture practices such as rice and cotton farming actually employ more people than shrimp or fish farming. For one shrimp farm, with an average of two ponds, only four people are needed for daily maintenance (Interview data 2014). Only during particular short periods, such as during a harvest or pond waste removal at the end of a harvest, are more people hired to help. During those periods, 20-40 people are hired. However, often the shrimp harvest employs people outside of the community who are in contract with the export companies rather than the shrimp farm owners (Interview data 2014). In contrast, rice farms that are 3-5 acres, for example, require on average 60 laborers during the season. Once one type of crop season is over, other crops are planted, meaning that those 60 laborers will have employment for several months rather than several days as in the aquaculture industry. Of course, many people are needed to process shrimp for export, removing heads and tails, deveining, and packing them in boxes. However, those activities do not take place within the village. Instead, once the shrimp is harvested, it is packed on ice and shipped to cities hours away where the processing plants are located. Therefore, shrimp farming provides more employment for urban areas rather than the targeted rural communities.

The problem of low employment associated with aquaculture versus agriculture is not a unique phenomenon to Poompuhar, however. My research findings support other studies, such as A. K. Deb’s in Bangladesh (1998), that estimate that shrimp farming reduces employment by 75\% compared to rice farming (Deb 1998). However overall, research shows that employment is higher than rice farming when you consider ancillary activities such as processing (Gowing et al. 2006). I estimate that this case is true for 
India, but I stress the importance of where employment is being generated (urban versus rural).

\section{Social Stratification}

I argued that one of the main reasons people in Poompuhar want to transition to aquaculture, specifically shrimp farming, is because they perceive it as profitable. However, with a closer look, I found that these profits were not affecting the wider community and only helping the families of aquaculture farm owners who are mostly from the middle-upper class. For example, just because an aquaculture farm was profitable did not mean that more workers were hired or that the existing workers would make more money (Interview data 2014). Daily wages for shrimp farm laborers were fixed across the board, at 450 rupees a day. This amount is the same for any type of nonskilled laborer in the village. A community member explained to me that the money made through aquaculture only stayed within the owner's family and did not trickle down to other households. In comparison, traditional agriculture practices in the village, such as rice farming, split profits between many households in a type of sharecropping system. There are a few local businesses in Poompuhar that are associated with the shrimp farming industry in particular, such as the shrimp feed store and the ice manufacturing plant. However, the owners of these companies are not from the poor sections of the village. The owner of the ice plant, for example, lives in one of the largest houses in the village. Therefore, in this case, shrimp farming is only allowing middle to upper class people to remain at the same high socio-economic level. 
Shrimp farming is not improving the socio-economic status of people who are below the poverty line; rather my interviews revealed that shrimp farming is in fact creating a large socio-economic divide within the village. The son of one of the most successful shrimp farmers in the village said to me, "Before shrimp farming we were all equal. Only after shrimp farming started did we have very rich people in the village” (Interview data 2014). This man’s father is considered a "big man” in the village and has great influence over the actions of other shrimp farmers and decisions within the community. He owns a large multi-storied house with several vehicles, all situated on an expansive piece of property. Without shrimp farming, he would not have achieved this status; an outcome that development planners did not foresee. It is important to note that this man's statement should be taken with a grain of salt, because certainly there were different socio-economic levels within the village before shrimp farming started. This historical stratification is connected to caste. Some portions of the village contained, and still do contain, groups of low-caste households, referred to as Scheduled Caste members or Dalits. However, this quote does demonstrate that changes to socio-economic stratification has occurred, perhaps intensifying the wealth of certain families. Consequently, it may also be leading to the introduction of more luxury items within the village, such as cars, big-screen televisions, and home computers, as wealthy shrimp farmers are able to purchase more. However, at the time of my research, none of these items was available for purchase within the village, meaning that if a household wanted to purchase a luxury item they would have to go to the nearest city, Mayiladuthurai, 45 minutes away by car. 


\section{Gendered Labor}

A primary focus of the global intimate literature is to highlight people and communities that are marginalized or alienated through processes of globalization (Mountz and Hyndman 2006). Mountz and Hyndman also argue that globalization “...produces and is produced by racialized, gendered, sexualized difference in specific ways” (2006: 449). Following this theme, another particularly "intimate” area affected by the aquaculture transition is the distribution of labor within the village and how this change is significantly gendered. Other studies have drawn attention to the "invisibility" of women in the fisheries and aquaculture sector, arguing that women make important contributions to fishery activities yet are often unaccounted in reports and census data (Weeratunge et al. 2010). This may be because women's contribution is in ancillary activities such as fish processing, or because they engage in unpaid labor (Alauddin and Hamid 1998). However, in Poompuhar I witnessed a different type of erasure of women in the labor force due to shrimp aquaculture, that is, a literal one. This erasure is apparent in Figure 10. The top image shows a group of women planting rice. The bottom image shows a group of men harvesting cultured shrimp. These two images are typical scenes in the village of Poompuhar and illustrate how labor is particularly gendered, where women work as agricultural laborers but not aquaculture laborers.

According to my interviews with community members in Poompuhar, women are a major part of the workforce for rice planting and cotton harvesting. The women that work as agricultural laborers are generally from lower income families or lower castes (Interview data 2014). Alternatively, my interviews revealed that one of the reasons 
women do not work on shrimp farms in Poompuhar is because villagers perceive the work as inappropriate for women due to the long work hours, sometimes during the night, involved in shrimp farming. Another reason that women are not involved as aquaculture laborers is linked to social class. As I have discussed in previous sections, the majority of shrimp farm owners are from the middle-upper class of the village because they have the land and money for starting a shrimp farm. However, my interviews revealed that in middle-upper class families there is social stigma if female family members work outside the home. Consequently, shrimp farm owners would rather hire outside labor than engage their female family members as laborers on the shrimp farm. And because shrimp farming requires less laborers than rice farming for example, men, who are expected to be the primary income earner in village households, are hired instead of women. As a result, only men engage in shrimp farming activities in Poompuhar, which means that the transition to shrimp aquaculture results in less available work for women from lower income or lower caste families.

Research conducted by Flaherty et al. (2009) concerning shrimp farming in Orissa, India found similar gendered labor patterns, particularly related to social class. They found that women's participation in shrimp farming is limited, and that the women who do participate are from lower castes. They also found that the majority of shrimp farm owners are from upper castes, and preferred not to allow their female family members to work on the shrimp farm. Flaherty et al. explains,

The primary reason given by the women respondents especially of upper caste, for non-participation in shrimp culture is social stigma which restricts women to go out of their house and work in a shrimp farm or elsewhere. Their spouses who are engaged in shrimp culture prefer to hire 
labourers to supplement the additional labour force required in the shrimp pond because they feel it as a dishonour to them if their women work (Flaherty et al. 2009: 127).

These results mirror the trends within the shrimp farming industry in Poompuhar, highlighting the point that gender and class are essential to understanding how aquaculture development may affect employment and household dynamics.

It is unclear how women feel about this change because I was unable to fully explore this area of investigation, owing to difficulty in soliciting interviews with women. However, I believe the ramifications of this gendered change in employment are most likely negative for women of lower income households or lower castes because they have fewer employment opportunities. My interactions and interviews revealed that women usually only take jobs if their family desperately needs the income or if they have higher education that allows them to take a skilled job (such as teaching or nursing). This point suggests that women who would traditionally participate in rice or cotton farming, would need the job to support their families, and would lament the loss of that job. Susie, a woman who makes fish pickle as income explained, that any income that she brings in to her household is for her to spend on whatever she wants, usually items that improve the quality of life of her family. For example, she uses her money to buy school supplies for her children and extra food items like milk. Without the extra income, she would not be able to purchase those items. 

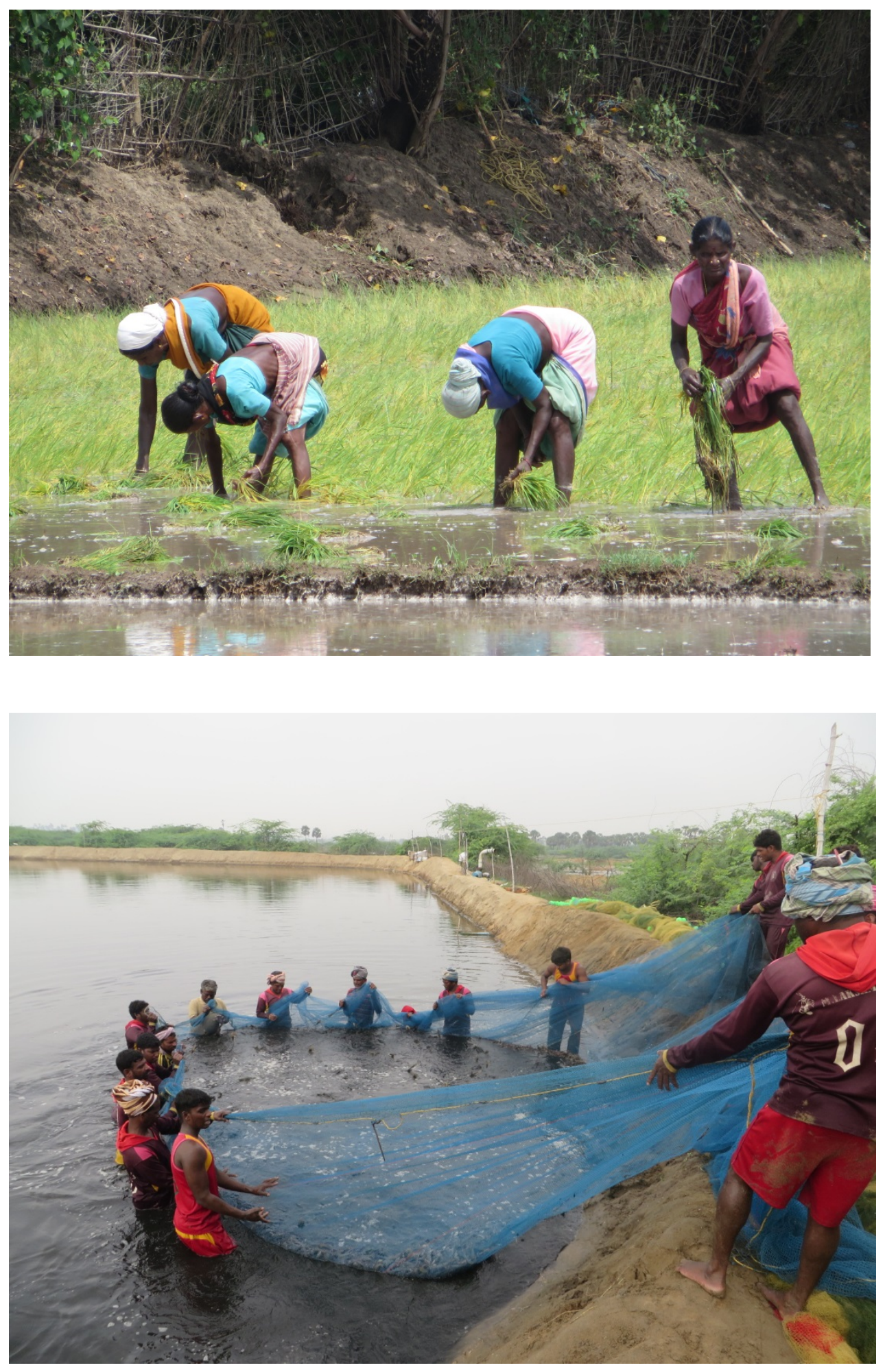

Figure 10. Scenes of Gendered Labor in Poompuhar 
Another factor leads me to believe that the loss of jobs for women in Poompuhar is detrimental for households - that is the disempowerment of women in contributing to financial decisions for the family. In many of my interviews with married women, they complained that any money their husbands got was quickly spent on alcohol. Even the husbands admitted that they would drink away their income if their wives did not take control of it. In fact, even a bank manager told me that the bank prefers to give loans to the women of a household rather than the men, because they have higher repayment rates with women. As a result, in many homes in Poompuhar, women control the household finances. However, studies suggest that if women are unable to contribute to the household income, they may lose some of their agency in making financial decisions (Ahmed 2001; Halim 2004). This means that the loss of agricultural work in Poompuhar could lead to domestic disputes or even financial difficulty.

The study by Flaherty et al. (2009) came to similar conclusions. They found that women believed that shrimp aquaculture was beneficial for the community and themselves only in cases where their households were directly benefitting from shrimp farms. In other words, the women in families that owned shrimp farms (generally higher caste families) benefitted from the profits made on the shrimp farm. However, particularly in one village where shrimp farming had become a contentious activity due to environmental conflict and uncertainties in the industry, women believed that shrimp farming was not benefitting them. In that case, women reported that shrimp farming had actually caused social conflict and consequently, affected the village women's ability to 
socialize outside of their homes. The negative responses regarding shrimp aquaculture also seem to be linked to lower social status.

These points highlight how the aquaculture transition, which is a product of globalization, may lead to the marginalization of women in the work force. Consequently, shrimp farming in particular, may affect family dynamics, the status of women, and household quality of life.

\section{Global Entanglements}

When I started this research project, I did not aim to specifically investigate the global networks of the aquaculture industry. However, during my field research, I realized that the local practices of shrimp farming in Poompuhar are difficult to separate from regional and international networks, and that in order to understand the effects of the aquaculture industry, one has to consider extralocal engagement. With such an entanglement between the village, district, state, and international community, it seems virtually impossible that commercial shrimp aquaculture could exist the way it does, without globalization.

In the previous section, I discussed how the aquaculture transition involves the inputs of new machinery. What I found, is that often the special equipment, machines, and even the shrimp stock itself, comes from outside of Poompuhar (see Table 3). In other words, shrimp aquaculture creates a web of material goods that spans the globe. In Poompuhar specifically, the process begins with licensed brood stock suppliers (approved by the Coastal Aquaculture Authority of India) that export Pacific White-leg shrimp seed 
to India that is then hatched at various hatcheries around the country. The shrimp seed in India comes from two countries, either Thailand or the US (see Table 3). All the shrimp farms in Poompuhar produce the Pacific Ocean variety of shrimp, a species non-native to India. This trend is not ubiquitous in India, however, as Pacific Ocean shrimp is only recently catching on with shrimp farmers. Once the shrimp hatch, they are shipped to the individual shrimp farms. Most of the other inputs such as feed and probiotics come from other areas of India or other countries in Asia. Asia dominates the aquaculture material market because Asian countries lead the world in the production of cultured seafood products.

In addition to the physical equipment and feed inputs, another type of input that is simultaneously global and intimate, is the connection between shrimp farmers and wider networks of knowledge. As I have described in the previous chapters, Indian research institutes such as the Rajiv Gandhi Centre for Aquaculture (RGCA) and the Central Institute of Brackishwater Aquaculture (CIBA) provide aquaculture training and extension services. 


\begin{tabular}{|c|c|c|}
\hline Input Material & Company Name & Origin \\
\hline \multirow[t]{7}{*}{ Broodstock, Shrimp Seed } & Oceanic Institute & Hawaii, USA \\
\hline & Kona Bay Marine Resources & Hawaii, USA \\
\hline & Shrimp Improvement Systems & Florida, USA \\
\hline & SyAqua & Bangkok, Thailand \\
\hline & Vannamei 101 Co. Ltd. & Phuket, Thailand \\
\hline & Charoen Pokphand Foods (CP) & Bangkok, Thailand \\
\hline & High Health Aquaculture Inc. & Hawaii, USA \\
\hline \multirow[t]{3}{*}{ Feed } & Bismi & Tiruvenkadu, India \\
\hline & Charoen Pokphand Foods (CP) & Bangkok, Thailand \\
\hline & Grobest & Taiwan \\
\hline \multirow[t]{4}{*}{ Probiotic and Supplements } & Charoen Pokphand Foods (CP) & Bangkok, Thailand \\
\hline & MicrobAsia Co. & Chennai, India \\
\hline & Biostadt India Limited & Mumbai, India \\
\hline & Tablets India Limited & Chennai, India \\
\hline \multirow[t]{4}{*}{ Aerator } & Sino Aqua & Taiwan \\
\hline & Nanrong & Shanghai, China \\
\hline & SRCS & Hyderabad, India \\
\hline & Nandini Gears & Coimbatore, India \\
\hline Water pump & Texmo & Coimbatore, India \\
\hline Engine & Kirloskar Group & Pune, India \\
\hline \multirow[t]{2}{*}{ Generator } & Leyland & England \\
\hline & Mitsubishi & Tokyo, Japan \\
\hline
\end{tabular}

Table 3. An itemized list of materials used on shrimp farms in Poompuhar, including the name of the company that manufactured/sold the item and where it originated (Interview data 2014; Coastal Aquaculture Authority 2016). 
If someone is interested in learning more about how to start their own aquaculture enterprise, he/she can take part in one of these training programs. Two shrimp farmers in Poompuhar reported that they took part in these programs. These institutes also offer water quality testing for shrimp farmers, which can help farmers know whether their pond water contains the correct nutrient levels or if there are bacteria contaminations. There is also a significant transfer of technical aquaculture knowledge from outside of India through other consulting services. Asian companies, such as Charoen Pokphand Foods (CP) based in Thailand, provide aquaculture consulting alongside the sale of their feed products. The consulting includes how to use their products, water quality standards, strategies for avoiding disease, and suggestions for increasing efficiency (Interview data 2014). For example, while I was in Poompuhar, a representative from CP came to the village and talked to the shrimp farmers about changing their pond stocking in order to increase growth rates and yields. CP also suggested a new type of aerator, called a longarm aerator, to improve efficiency. Just from this one meeting, all of the shrimp farmers in Poompuhar decided to change their practices and try the new stocking method. They were a bit skeptical that it would increase efficiency as much as the consultants were saying, but the farmers told me that if it did not work, they would just go back to their old method for the next season. These consulting companies have a stake in the cultured shrimp market through the sale of products, therefore if productivity increases, they stand to profit as well. A significant point about the network of specialized aquaculture knowledge is that it seems to only flow into Poompuhar from outside sources, rather than a bi-directional knowledge exchange. The shrimp farmers in the village do have their own organization, which meets at least once every crop cycle and allows them to trade 
ideas and experiences. However, no one I spoke to ever described an instance in which the knowledge shared during these meetings was shared with the consultants who visited their village.

The aquaculture transition in Poompuhar has also opened the local labor market up to non-local workers. Traditionally, local community members fill agricultural work in the village but in the case of shrimp farming, outside laborers are hired to help during the harvest. When a shrimp pond is ready for harvest, the shrimp farm owner calls a broker and notifies them that the shrimp are ready to be sold. The broker notifies an export company, and arranges for them to pick up the harvest. The export company arrives at the shrimp farm with their own laborers and the laborers proceed to harvest the shrimp, pack it on ice, and transport it to the processing facilities. I believe the export company prefers to use non-local laborers to cut costs because non-local workers are willing to work for less money, a fact that was mentioned in my interviews. My interview with laborers hired by the Diamond Seafood export company also revealed that all of the workers were from India, but all of them were from outside of the village. Most of them were from Nagore, within the same district as Poompuhar, while others were from Punjab and Gujarat (states further north). These workers are hired by the export company and travel around India to different shrimp farms helping with the harvest. In some cases, local men will also be hired on a daily basis to supplement the export company's workforce if needed. From my interviews with laborers within Poompuhar, I got a feeling that the hiring of non-local workers for shrimp harvest work caused animosity and discontent within the village towards the export company because the villagers felt as 
though their work was being taken away from them. During one shrimp harvest I witnessed, I noticed groups of local village men standing on the edge of the farm property, looking on as if they were jealous. I believe the introduction of non-local workers creates potential conflict between villages and export companies, as well as prejudices against non-local laborers.

\section{Conclusion}

Feminist scholars Alison Mountz and Jennifer Hyndman (2006) assert, “...the intimate is inextricable from the global. They are neither separate spheres nor bounded subjects” (2006: 448). In this chapter, I have built upon this re-conceptualization of the scales of globalization to demonstrate how global and intimate processes entangle as part of the aquaculture transition that is taking place in Poompuhar. Specifically, I discussed how the global demand for seafood has led to the intensification of cash cropping and the introduction of monoculture shrimp farming, both of which have significant implications for the local agrarian structure. The practice of commercial shrimp farming, a major driver of the aquaculture transition in Poompuhar, has also changed the local economy of Poompuhar. It has connected practitioners to global markets as an export commodity and changed patterns of employment and labor. As a result, aquaculture practitioners are exposed to new risks. I have also argued in this chapter that shrimp aquaculture in particular, has significant impacts upon village social relations. It has increased social stratification by boosting the incomes of select families while others are cut out of the profits. The transition to commercial aquaculture has also changed women's employment by decreasing the availability of paid work due to gendered labor practices. I have also 
discussed how the aquaculture transition involves complex entanglements in multiscalar networks of materials, knowledge, and labor that have connections to both the global and the intimate.

I believe that understanding these entanglements allows scholars and development managers to understand the impacts that globalization has upon agrarian societies - how the demand for shrimp in places like the United States leads to loss of jobs, changing social relations and greater vulnerabilities in small villages like Poompuhar. Using the global intimate as a conceptual framework helps to illuminate the various scales involved and draw attention to the people that are marginalized by such processes. Ultimately, this knowledge could help mitigate some of the negative side effects of the aquaculture transition, such as the erasure of women from the labor force and the exposure to financial risk through the spread of mono-cropping. 


\section{CHAPTER VII. CONCLUSION}

Sometimes the best way to end things is to bring everything full circle, back to the beginning. Let me explain how this project all started and why I am interested in aquaculture. My interest in aquaculture began during my undergraduate college career. I was a marine biology student and started a senior thesis project at a local aquarium shop on the Eastern Shore of Maryland. The shop sold exotic fish and corals to aquarium hobbyists and generally, people who spent thousands of dollars keeping a salt-water fish tank as a decorative piece in their home or office. The shop procured its merchandise mainly in two ways: collections in the Solomon Islands, and propagating corals and invertebrates (on site) through asexual reproduction. In other words, if you take a clipping from a living piece of coral or cut a sea anemone in half, you can grow another one. In essence, this is a type of aquaculture. It is important to note that the collections in the Solomon Islands were also products of an aquaculture process, not "wild" collections. The shop owner had established a program with locals in the islands where they would propagate corals and grow them in the ocean on small discs, on the reef itself. When they had grown a sufficient amount, the discs, now covered in living coral, would be collected and shipped to Maryland. By doing so, the Solomon Island locals would get an income. It was a great arrangement that benefitted both the community as well as the shop owner, while also conserving wild coral reefs.

However, the shop owner was interested in experimenting with coral propagation techniques to find the most efficient and successful method, thereby eliminating the need to ship as many corals from the Solomon Islands and ultimately increasing his profits. He 
agreed to have me conduct such experiments at his shop so that I could fulfill my senior thesis requirement, at the same time he learned better propagation techniques. My research at his shop introduced me to the world of aquaculture, something I had known nothing about prior to my project. It showed me the possibilities of applications for coral reef restorations but also opened the door for many more questions. How was the reef in the Solomon Islands affected by the aquaculture program? Was the arrangement really beneficial to the local community? Were they experiencing any changes in their community as a result of the new source of income? What other stakeholders were involved in the global aquaculture industry? I started to realize that that little aquarium shop, located down a dusty unpaved driveway in an obscure rural town, was entangled in much larger networks of global trade, consumption, and labor.

Following my research at the local aquarium shop in Maryland, I worked as a science intern at the Maryland Coastal Bays Program, a non-profit organization involved in environmental research, conservation, and education. The organization helps collect population data of local wetland and marine species and works with the community to preserve and restore native habitats. However, while I was working there, the lead science coordinator explained to me one of the challenges of doing the type of work that the organization does. He told me that one of the difficulties is identifying the needs of environmental stakeholders, such as commercial fishermen, local homeowners, and farmers. He said there was a need for more people to specialize in fostering humanenvironmental relationships, in other words, more environmental anthropologists. 
As I finished my bachelor's degree and moved on to my graduate career, these questions about aquaculture, my interest in marine and environmental issues, and the call for more social science research swirled in my mind. This dissertation project is the culmination of me connecting all the dots. I combined my experience in marine biology with my thirst for exploring questions about the commercial aquaculture industry and entered the Global and Sociocultural Studies program. When I started to delve into the aquaculture literature, I found some gaping holes.

I found that aquaculture practices are responsible for producing nearly half of the world's seafood yet when I talked to people, they had not heard of such processes. I learned that India is one of the world's top producers of aquaculture products, yet most studies take place in South America or East Asia. What materials there are concerning the aquaculture industry in India, mention widespread protests against shrimp farming in the 1990s yet there are few follow-ups on the situation in more recent times. Why did shrimp aquaculture dominate the Indian industry? Were the social and environmental problems associated with shrimp farming resolved? What are people's opinions about aquaculture now? This series of events and questions led to my decision to study aquaculture in India and as I continued to investigate, I discovered more reasons that make this research important.

Ultimately, the purpose and importance of this dissertation is to highlight how specific conceptualizations of development and progress determine patterns of food production and consumption. And in turn, how these patterns of production and 
consumption leave their mark on the social relations and biophysical environments in the communities that are the targets of these development paradigms.

\section{Analysis and Major Findings}

My analysis of the rich qualitative data has enhanced anthropological understandings of aquaculture livelihood systems in several key ways. First, I used archival materials to trace the historical legacies of the development project within the expansion of the commercial aquaculture industry in India. This analysis sets the stage for further discussions of the processes and discourses that drive contemporary development of aquaculture practices. Additionally, while scholars such as Vandana Shiva (2000) and Stonich and Bailey (2000) have compared the emergence of commercialized aquaculture (the Blue Revolution) to the industrialization of the agriculture sector (the Green Revolution), I believe their comparisons have only scraped the surface in terms of explaining how and why these processes are similar. I argued that the commercial aquaculture industry emerged as part of a broader turn towards investing in development in India that involved the Green Revolution as well, and that the same initiatives of rural development continue to drive aquaculture expansion in contemporary times. I specifically analyzed the areas of food security, environmental impacts, and gendered issues in my analysis, discussing the similarities and important divergences between the Green and Blue Revolutions.

The second contribution of this dissertation to anthropological studies is an analysis of stakeholder perceptions involved in commercial aquaculture. I compared the perspectives and goals of development workers and researchers to aquaculture 
practitioners. My analysis found that there is a disparity between the goals of aquaculture development programs and actual aquaculture practices, which I attribute to a state of “estrangement.” I argued that the estrangement, defined as a lack of engagement and participation between aquaculture managers, researchers, and practitioners is caused by the technocratic and top-down governance structure of the aquaculture industry. I highlighted four main ways in which the technocratic, top-down governance creates this estrangement: 1) a lack of participatory approaches, 2) a mismatch between the groups of people extension programs target and actual aquaculture practitioners, 3) a lack of NGOs, and 4) lack of trust between stakeholders.

The third contribution that this dissertation makes is by linking the interactions of stakeholders to the creation of vulnerability and risk. I argued that the estranged relationship between aquaculture stakeholders ultimately leads to a failure of development programs and aquaculture management, which in turn makes the communities in which aquaculture is being practiced more vulnerable to disturbances. These findings demonstrate how rural development programs can have unintended effects upon communities that are already pre-disposed to certain socio-economic and biophysical risks.

The fourth contribution of this dissertation is the discussion of how aquaculture is used as a special type of rural development technique, that is, as a post-disaster recovery strategy. I argued that the way in which development practitioners promoted aquaculture as an alternative livelihood technique following the tsunami of 2004, is an example of the contemporary forms of the development project. In other words, commercial aquaculture 
as a recovery strategy perpetuates the development discourse in a "rebranded" way. However, this process not only served to further the goals of rural development programs, but also served to expand aquaculture research. I argued that the added attention and funding to livelihood training programs following the tsunami led to the construction of key aquaculture research and extension facilities. However, I illustrate that despite the efforts to diversify local livelihoods, specifically aquaculture practices, actual livelihoods in Poompuhar are largely unchanged.

The final contribution that this dissertation makes is explaining how the aquaculture transition in Poompuhar is taking place and how it has changed agrarian structures and livelihoods within the community. Through a detailed analysis of interview data, I uncovered two main factors that motivate people to transition to aquaculture; those are economic forces, and what I describe as a feeling of "last resort.” These findings support other case studies of aquaculture transitions in different areas, pointing to a common trend in the spread of commercial aquaculture, specifically shrimp farming (Deb 1998; Flaherty et al. 2009; Ito 2002). My analysis also explains how the aquaculture transition in Poompuhar has led to the intensification of cash-cropping practices as people switch from farming cotton and rice to farming shrimp. This process has led to the introduction of an export commodity market within the village, connecting villagers to broader networks of trade, materials, and social relationships as well as exposing them to greater economic and environmental risk. Additionally, I highlighted the implications that changing livelihood practices has on village food security, employment, social stratification, and gendered labor patterns. Overall, the analysis suggests that the rise of 
shrimp farming in Poompuhar has been largely detrimental to households and the wider community.

\section{Contributions to Theory}

This dissertation makes two significant contributions to theory. The first contribution that this study makes is to the field of development studies, specifically postdevelopment theory. Numerous scholars have investigated the ways in which development programs impact local communities and the ways in which such programs can improve. One common critique that James Ferguson (1994), Tania Murray Li (2007), as well as others make, is that development programs are often designed in such a way as to legitimize the interventions of "experts” or "technocrats" (Mitchell 2002; Rivera-Ferre 2009). My dissertation research demonstrates similar processes involved in the expansion of commercial aquaculture in India, yet I go further by connecting this process with theories of vulnerability and risk. I argue that the social production of vulnerability as theorized by Blaikie et al. (1994) also applies to the case of aquaculture as rural development, where a technocratic governance structure leads to stakeholder estrangement and the creation of vulnerability. Therefore, to use Ferguson's terminology, the "side-effect" of aquaculture development programs in India is the further marginalization of local community members through problems of environmental degradation and agrarian change. I believe that connecting post-development theory to that of vulnerability and risk is helpful in thinking about the ways in which development programs affect communities, particularly whether or not they improve community resilience. By using the language of vulnerability and risk, it makes critiques of 
development programs more tangible to development professionals and may be more persuasive for changing their practices.

The second contribution that this dissertation makes to theory is through the application of the global intimate in analyzing the multiscalar affects and connections of the commercial aquaculture industry. Thus far, scholars have used the theory of the global intimate to analyze representation and identity formations in relation to global capitalism (Cahill 2006). Similarly, Cindi Katz (2001) explores how globalization affects people in different places and in different ways, particularly through gendered labor. There is also a large body of work concerning sexuality and intimacy in a transnational context that seeks to investigate how political, racial, and gender boundaries are broken (Lee 2012; Rius 2012; Wood 2006). These studies make important contributions to unraveling the multiscalar processes of globalization; however, more attention is needed

concerning aquaculture livelihood practices or rural development programs. Because both of these issues are embedded within global and "intimate" scales, the theory of the global intimate is a useful way to highlight how these processes entangle. Specifically, it is an effective way to think about how the commercial development of aquaculture affects things such as household dynamics, social interactions, knowledge production, food production/consumption, and even risk.

\section{A Note on Generalizability and Future Directions}

Due to resource constraints, this study focused on only one village in Tamil Nadu, India. Like other case studies, the scope of the research restricts the generalizability of the findings and analysis. In other words, the findings do not necessarily apply to other 
communities or other instances of aquaculture development. However, comparisons to other work concerning the social impacts of aquaculture do make a case for the applicability of the findings to other areas, particularly in India. Additionally, there are several avenues for future research that would expand the scope of generalizability of the research findings.

First, the dissertation findings could benefit from a comparative study in another region of India. This would allow for greater generalizability as well as uncover a better understanding of how aquaculture expansion, in its various forms, takes place throughout the country. For example, the work of Bhatta and Bhat (1998) suggest that commercial shrimp aquaculture in particular may have followed a different model of expansion in Kerala, through the spread of corporate farms. I believe that process would be important to investigate, as well as updating any findings from their 1998 study. A comparative study could explore how and why aquaculture expansion is different and what implications it may have on local communities in Kerala. Additionally, data collection at another site could allow for a deeper investigation of other types of aquaculture activities such as seaweed cultivation or seabass cage culture, which the current study did not have the opportunity to explore.

Another important direction for future research is an investigation of the beginning of the aquaculture commodity chain, i.e. seed hatcheries, the sites that provide shrimp or fish seed. This is an understudied area of aquaculture and I believe that it would provide important insights into the impacts that seed production and collection have on the communities in which they are located. This would involve data collection 
not only in India, at local hatcheries, but also in the United States where many of the shrimp seed suppliers are located.

A final suggestion for further research on this topic would be a longitudinal study in Poompuhar and the broader area of Tamil Nadu. This would provide a deeper understanding of changes over time, and perhaps highlight some changes that were less apparent during my data collection. This would also increase the ethnographic richness of the study and provide more opportunities for building rapport with community members, which would ultimately help in accessing the perspectives of some of the unrepresented sections of the community. 


\section{LIST OF REFERENCES}

Abila, R. O. 2003. Fish trade and food security: Are they reconcilable in Lake Victoria. Rome: FAO.

Adger, W. Neil. “Vulnerability.” Global Environmental Change 16 (2006): 268-281.

Aducci, M. 2009. Neoliberal Wave Rocks Chilika Lake, India: Conflict over Intensive Aquaculture from a Class Perspective. Journal of Agrarian Change 9(4): 484-511.

Agüero, M. and E. González. 1997. Aquaculture economics in Latin America and the Caribbean: a regional assessment. In A.T. Charles, R.F. Agbayani, E.C. Agbayani, M. Agüero, E.T. Belleza, E. González, B. Stomal \& J-Y. Weigel, eds. Aquaculture economics in developing countries: regional assessments and an annotated bibliography, pp. 28-34. FAO Fisheries Circular No. 932. Rome.

Ahmed, Nesar. 2001. "Socio-Economic Aspects of Freshwater Prawn Culture Development in Bangladesh.” Scotland, UK: University of Stirling.

Alauddin, M., and M.A. Hamid. "Coming Out of Their Homesteads? Employment for Rural Women in Shrimp Aquaculture in Coastal Bangladesh.” International Journal of Social Economics 25, no. 2-4 (1998): 314.

Asian Development Bank. Tsunami Emergency Assistance Project Action Taken Report. Government of Tamil Nadu Disaster Management and Mitigation Department, October 31, 2009.

Babbie, Earl R. 1998. The Practice of Social Research. Wadsworth Publishing Company.

Baker, Kathleen and Sarah Jewitt. 2007. "Evaluating 35 Years of Green Revolution Technology in Villages of Bulandshahr District, Western UP, North India.” Journal of Development Studies 43(2): 312-339.

Banerjee, Abhijit, and Lakshmi Iyer. 2002. "History, Institutions and Economic Performance: The Legacy of Colonial Land Tenure Systems in India.” Working Paper 02-27. Massachusetts Institute of Technology Department of Economics Working Paper Series. Cambridge, MA: Massachusetts Institute of Technology.

Barraclough, Solon, and Andrea Finger-Stich. 1996. "Some Ecological and Social Implications of Commercial Shrimp Farming in Asia.” UNRISD Discussion Paper 74. Geneva: United Nations Research Institute for Social Development and World Wide Fund for Nature-International. 
Barrett, Christopher B., and Mark A. Constas. 2014. "Toward a Theory of Resilience for International Development Applications.” Proceedings of the National Academy of Sciences 111 (40): 14625-30. doi:10.1073/pnas.1320880111.

Barrett, Gene, Mauricio I. Caniggia, and Lorna Read. 2001. “"There Are More Vets than Doctors in Chiloe' Social and Community Impact of the Globalization of Aquaculture in Chile.” In Social Capital and Globalization, 36. Faroes.

Barton, Jonathan R., and Arnt Floysand. 2010. "The Political ecology of Chilean salmon aquaculture, 1982-2010: A trajectory from economic development to global sustainability.” Global Environmental Change 20: 739-752.

Batliwala, S. 2007. “Taking the power out of empowerment - an experiential account.” Development in Practice 17(4-5): 557-565.

Baviskar, Amita. 1995. In the belly of the river: tribal conflicts over development in the Narmada Valley. Delhi: Oxford University Press.

Beck, Ulrich. 1992. Risk Society: Towards a New Modernity. 1 edition. London; Newbury Park, Calif: SAGE Publications Ltd.

BEDROC. 2009. "Building Local Capacities for Disaster Response and Risk Reduction: An Oxfam-BEDROC Study.” Nagapattinam, India.

Belton, Ben, and David Little. 2008. “The Development of Aquaculture in Central Thailand: Domestic Demand versus Expor-Led Production.” Journal of Agrarian Change 8(1): 123-143.

Bernard, H. Russell. 2011. Research Methods in Anthropology: Qualitative and Quantitative Approaches. 5 edition. Lanham, Md: AltaMira Press.

Bernstein, Henry, and Terence J. Byres. 2001. "From Peasant Studies to Agrarian Change.” Journal of Agrarian Change 1 (1): 1-56. doi:10.1111/1471-0366.00002.

Besley, Timothy and Robin Burgess. 2000. "Land Reform, Poverty Reduction, and Growth: Evidence from India.” The Quarterly Journal of Economics: 389-430.

Bhat, M. G. and R. Bhatta. 2004. "Considering Aquacultural Externality in Coastal Land Allocation Decisions in India." Environmental and Resource Economics 29(1): 1-20.

Bhatta, R. and M. Bhat. 1998. Impacts of aquaculture on the management of estuaries in India. Environmental Conservation 25(2): 109-121.

Blaikie, P., B. Wisner, T. Cannon, and I.Davis. At Risk: Natural Hazards, People's Vulnerability and Disasters. London: Routledge, 1994. 
Borlaug, Norman. 2004. “Biotech Can Feed 8 Billion.” New Perspectives Quarterly 21 (4): 97-102. doi:10.1111/j.1540-5842.2004.00706.x.

Bouis, H., 2000. Commercial vegetable and polyculture fish production in Bangladesh: their Impacts on household income and dietary quality. Food and Nutrition Bulletin 21 (4), 482-487.

Boyd, Claude E. 2002. Mangroves and Coastal Aquaculture. In Responsible Marine Aquaculture. R. Stickney and J. McVey, eds. Pp. 145-158. Wallingford, U.K.: CABI Publishing Co.

Briggs, Matthew, Simon Funge-Smith, Rohana Subasinghe, and Michael Phillips. 2004. "Introductions and Movement of Penaeus Vannamei and Penaeus Stylirostris in Asia and the Pacific.” RAP publication. Bangkok: Food and Agriculture Organization of the United Nations Regional Office for Asia and the Pacific.

Bush, S. R., and M. J. Marschke. 2014. Making social sense of aquaculture transitions. Ecology and Society 19(3): 50. http://dx.doi.org/10.5751/ES-06677-190350

Cahill, Caitlin. 2006. “'At Risk’? The Fed Up Honeys Re-Present the Gentrification of the Lower East Side.” Women’s Studies Quarterly 34 (1/2): 334-63.

Cai, J., P. Leung, and N. Hishamunda. 2009. Commercial aquaculture and economic growth, poverty alleviation and food security: assessment framework. FAO Fisheries and Aquaculture Technical Paper. No. 512. Rome: FAO.

Chakravarti, A. K. 1973. "Green Revolution in India.” Annals of the Association of American Geographers 63(3): 319-330.

Chandrasekharan, H., A. Sarangi, M. Nagarajan, V.P. Singh, D.U.M. Rao, P. Stalin, K. Natarajan, B. Chandrasekaran, and S. Anbazhagan. 2008. "Variability of soil-water quality due to Tsunami-2004 in the coastal belt of Nagapattinam district, Tamilnadu." Journal Of Environmental Management 89, no. 1: 63-72. Academic Search Complete, EBSCOhost (accessed May 12, 2016).

Charles, A.T., R.F. Agbayani, E.C. Agbayani, M. Agüero, E.T. Belleza, E. González, B. Stomal, and J.Y. Weigel. 1997. Aquaculture economics in developing countries: regional assessments and an annotated bibliography. FAO Fisheries Circular No. 932. Rome.

Clay, Jason W. 2004. World Agriculture and the Environment: A Commodity-ByCommodity Guide To Impacts And Practices. Island Press.

CMFRI. 2015. “Vision 2050.” Kochi, Kerala: Indian Council of Agricultural Research. 
Coastal Aquaculture Authority. 2016. "Attention: Hatcheries Importing SPF L Vannamei Brood Stock.” http://www.caa.gov.in/uploaded/doc/attn_importspfbroodstock-18-042016.pdf.

Cope, Meghan. 2010. “Coding Qualitative Data.” In Qualitative Research Methods in Human Geography, 3rd edition, 281-94. Ontario: Oxford University Press.

Corbin, Juliet, and Anslem Strauss. Basics of Qualitative Research 3e. 3rd ed. London: Sage Publications, 2008.

Costa-Pierce, Barry A. 2002. Farming Systems Research and Extension Methods for the Development of Sustainable Aquaculture Ecosystems. In Ecological Aquaculture: The Evolution of the Blue Revolution. Barry A Costa-Pierce, ed. Pp. 103-124. Oxford: Blackwell Science.

Cullather, Nick. The Hungry World America’s Cold War Battle Against Poverty in Asia. Cambridge, Mass.: Harvard University Press, 2010.

Dasgupta, Sugata. 1985. Towards a Post-Development Era: Essays in Poverty, Welfare, and Development. Mittal Publications.

Davis, D. Allen, Tzachi M. Samocha, and C.E. Boyd. 2004. “Acclimating Pacific White Shrimp, Litopenaeus Vannamei, to Inland, Low-Salinity Waters.” Fact sheet 2601. SRAC Publication. USA: Southern Regional Aquaculture Center.

Deb, A.K. 1998. "Fake blue revolution: environmental and socio-economic impacts of shrimp culture in the coastal areas of Bangladesh.” Ocean Coast. Manage. 41(1): 63-88.

Dewalt, Billie R., Philippe Vergne, and Mark Hardin. 1996. "Shrimp Aquaculture Development and the Environment: People, Mangroves and Fisheries on the Gulf of Fonseca, Honduras.” World Development 24(7): 1193-1208.

Dierberg, F.E. and W. Kiattisimkul. 1996. "Issues, impacts, and implications of shrimp aquaculture in Thailand. Environmental Management 20: 649-666.

Escobar, Arturo. Encountering Development: The Making and Unmaking of the Third World. New Jersey: Princeton University Press, 1995.

Escobar, Arturo. Territories of Difference: Place, Movements, Life, Redes. Durham: Duke University Press, 2008.

Esteva, Gustavo, and Madhu Suri Prakash. 1998. Grassroots Post-Modernism: Remaking the Soil of Cultures. Palgrave Macmillan. 
Falcon, Walter, Ashley Dean, Rosamond Naylor, Ivan Ortiz-Monasterio, David Lobell, John Harrison, Toby Ahrens, et al. 2011. Seeds of Sustainability: Lessons from the Birthplace of the Green Revolution in Agriculture. Edited by Pamela A. Matson. 1 edition. Washington, DC: Island Press.

FAO. 2007. "Improving Penaeus Monodon Hatchery Practices: Manual Based on Experience in India.” FAO Fisheries Technical Paper 446. Rome.

FAO. 2016. Aquaculture topics and activities. Aquaculture. In: FAO Fisheries and Aquaculture Department [online]. Rome. Updated 14 September 2015. [Cited 28 April 2016]. http://www.fao.org/fishery/aquaculture/en

FAO. 2012. Report of the Global Conference on Aquaculture 2010 - Farming the Waters for People and Food. Rome: FAO Fisheries and Aquaculture.

Ferguson, James. 1994. The Anti-Politics Machine: Development, Depoliticization, and Bureaucratic Power in Lesotho. Minneapolis: University of Minnesota Press.

Flaherty, M., K. C. Samal, D. Pradhan, and S. Ray. Coastal Aquaculture in India: Poverty, Environment and Rural Livelihoods. New Delhi: Concept Publishing Company, 2009.

Freed, Stanley A., and Ruth S. Freed. 2002. "Green Revolution : Agricultural and Social Change in a North Indian Village. Anthropological Papers of the AMNH ; No. 85." http://digitallibrary.amnh.org/handle/2246/311.

Gadgil, Madhav and Ramachandra Guha.1993. This Fissured Land: An Ecological History of India. California: University of California Press.

Gaillard, J.C. 2010. "Vulnerability, Capacity and Resilience: Perspectives for Climate and Development Policy.” Journal of International Development 22 (2): 218-32. doi:10.1002/jid.1675.

Gillett, R. Global Study of Shrimp Fisheries. FAO Fisheries Technical Paper. Rome: Food and Agriculture Organization of the United Nations, 2008.

Glaeser, Bernhard. The Green Revolution Revisited: Critique and Alternatives. Taylor \& Francis, 1987.

Gowing, J.W., T.P. Tuong, and C.T. Hoanh. 2006. "Land and Water Management in Coastal Zones: Dealing with Agriculture-Aquaculture-FIshery Conflicts.” In Environment and Livelihoods in Tropical Coastal Zones: Managing Agriculture-FisheryAquaculture Conflicts, 1-16. Oxon, UK: CABI International. 
Gujja, B. and A. Finger-Stich. 1996. "What Price Prawn?: Shrimp Aquaculture’s Impact in Asia.” Environment 38(7): 12-39.

Gunderson, Lance H. "Ecological Resilience - In Theory and Application.” Annual Review of Ecology and Systematics. 31 (2000): 425-439.

Gupta, Akhil. 1998. Postcolonial Developments: Agriculture in the Making of Modern India. Duke University Press.

Halim, Sadeka. 2004. "Marginalization or Empowerment? Women’s Involvement in Shrimp Cultivation and Shrimp Processing Plants in Bangladesh." In Women, Gender and Discrimination, 95-112. Rajshahi: University of Rajshahi.

Hershberger, William K. 2002. Genetic Changes in Marine Aquaculture Species and the Potential for Impacts on Natural Populations. In Responsible Marine Aquaculture. Robert R. Stickney and James P. McVey, eds. Pp. 221-232. Wallingford: CABI Publishing.

Holling, C.S. "Resilience and Stability of Ecological Systems.” Annual Review of Ecology and Systematics 4 (1973): 1-23.

Hopkins, Stephen J., M. Richard DeVoe, and A. Frederick Holland. 1995.

"Environmental Impacts of Shrimp Farming with Special Reference to the Situation in the Continental United States.” Estuaries 18(1A): 25-42.

Islam, Saidul. 2014. Confronting the Blue Revolution: Industrial Aquaculture and Sustainability in the Global South. University of Toronto Press.

Ito, S. 2002. "From rice to prawns: Economic transformation and agrarian structure in rural Bangladesh.” Journal of Peasant Studies 29(2): 47-70.

Katz, Cindi. 2001. "On the Grounds of Globalization: A Topography for Feminist Political Engagement.” Signs: Journal of Women in Culture and Society 26 (4): 1213-34.

Kapila, R. and Kapila, U. (eds) (2002) Indian Agriculture in the Changing Environment, Vols. 1 and 2 (Delhi: Academic Foundation).

Kearns, Robin A. 2010. "Seeing with Clarity: Undertaking Observational Research.” In Qualitative Research Methods in Human Geography, 3rd edition, 241-58. Ontario: Oxford University Press.

Khan, S. A. 2011. "Decentralization and Women Empowerment: Exploring the Linkages.” Journal of Political Studies. Academic OneFile. Web. 30 Nov. 2011.

Kurien, J. State and Shrimp: A Preliminary Analysis of the Economic and Ecological Consequences of India's Fishery Policies. Bangkok: FAO Technical Consultation, 1997. 
Kutty, Methil Narayanan. 2005. “Towards sustainable freshwater prawn aquaculture lessons from shrimp farming, with special reference to India.” Aquaculture Research 36:255-263.

Lee, Min Jin. 2012. "What We Women Talk About When We Talk About Interracial Love.” In The Global and the Intimate: Feminism in Our Time, 232-42. Gender and Culture. Columbia University Press.

Lewis, James, and Ilan Kelman. 2010. "Places, people and perpetuity: Community capacities in ecologies of catastrophe.” ACME 9(2): 191-220.

Lewis, R.R. III, M.J. Phillips, B. Clough and D.J.Macintosh. 2003. Thematic Review on Coastal Wetland Habitats and Shrimp Aquaculture. Report prepared under the World Bank, NACA, WWF and FAO Consortium Program on Shrimp Farming and the Environment. Work in Progress for Public Discussion.Published by the Consortium. 81 pages.

Li, Tania. The Will to Improve: Governmentality, Development, and the Practice of Politics. Durham, NC: Duke University Press, 2007.

Lipton, Michael, and Richard Longhurst. 2010. New Seeds and Poor People. Routledge.

Magis, K. “Community resilience: an indicator of social sustainability.” Soc. Nat. Resour. Int. J. 23, no.5 (2010): 401-416.

McGuirk, Pauline M., and Phillip O’Neill. 2010. “Using Questionnaires in Qualitative Human Geography.” In Qualitative Research Methods in Human Geography, 3rd edition, 191-216. Ontario: Oxford University Press.

McMichael, Philip. Development and Social Change: a Global Perspective. Los Angeles: SAGE, 2012.

Ministry of Agriculture. Report on the working group on fifth year plan (1974-1979) fisheries. New Delhi, 1973.

Ministry of Agriculture and Irrigation. Report on the National Commission on Agriculture, 1976, Part VIII, Fisheries. New Delhi, 1976.

Mitchell, Timothy. Rule of Experts: Egypt, techno-politics, modernity. Berkley: University of California Press, 2002.

Mountz, Alison, and Jennifer Hyndman. 2006. "Feminist Approaches to the Global Intimate.” Women's Studies Quarterly 34 (1/2): 446-63. 
MPEDA. 2015. "State-Wise Details of Shrimp and Scampi Production.” The Marine Products Export Development Authority. http://164.100.150.120/mpeda/cms.php?id=eWVhci13aXNlLXNwZWNpZXMtd2lzZS1z dGF0ZS13aXNl\#.

MSSRF. n.d. "Fish For All Research and Training Centre."

Mukherjee, Amitava. 1994. “ India’s farmers could be world's top suppliers.” Fish Farming International 21(7): 12-13.

Mutchnick, Robert J., and Bruce L. Berg. 1995. Research Methods for the Social Sciences: Practice and Applications. Pearson.

“Nagapattinam District, Tamil Nadu, INDIA | Tsunami Relief.” 2016. Accessed May 22. http://www.nagapattinam.tn.nic.in/relief.html.

NFDB. n.d. "Guidelines for Intensive Aquaculture in Ponds and Tanks.”

Niazi, Tarique. 2004. "Rural Poverty and the Green Revolution: Lessons from Pakistan.” The Journal of Peasant Studies 31(2): 242-260.

Ocampo-Thomason, P. 2006. Mangroves, People and Cockles: Impacts of the ShrimpFarming Industry on Mangrove Communities in Esmeralda Province, Ecuador. In Environment and Livelihoods in Tropical Coastal Zones: Managing Agriculture-FisheryAquaculture Conflicts. eds. Chu Thai Hoanh, To Phuc Tuong, John W. Gowing and Bil Hardy. Cambridge: CAB International.

Orr, Alastair. "Why were So Many Social Scientists Wrong about the Green Revolution? Learning from Bangladesh.” The Journal of Development Studies 48, no. 11 (2012): 1565-1586.

Oxfam.1995. The Oxfam Handbook of Relief and Development. Oxford: Oxfam.

Pant, Jharendu, Benoy Kumar Barman, Khondker Murshed-E-Jahan, Benjamin Belton, and Malcolm Beveridge. 2014. "Can Aquaculture Benefit the Extreme Poor? A Case Study of Landless and Socially Marginalized Adivasi (ethnic) Communities in Bangladesh.” Aquaculture 418-419 (January): 1-10.

doi:10.1016/j.aquaculture.2013.09.027.

Pant, J., M.K. Shrestha, and R.C. Bhujel. 2012. "Aquaculture and Resilience: Women in Aquaculture in Nepal.” In Small-Scale Aquaculture for Rural Livelihoods: Proceedings of the Symposium on Small-Scale Aquaculture for Increasing Resilience of Rural Livelihoods in Nepal, 19-24. Institute of Agriculture and Animal Science, Tribhuvan University, Chitwan, Nepal and The WorldFish Center, Penang, Malaysia. 
Paez-Osuna, Federico, Saul R. Guerrero-Galvan, and Ana C. Ruiz-Fernandez. 1998. “The environmental impact of shrimp aquaculture and the coastal pollution in Mexico.” Marine Pollution Bulletin 36(1): 65-75.

Pearse, Andrew Chernocke. 1980. Seeds of Plenty, Seeds of Want: Social and Economic Implications of the Green Revolution. Oxford : New York: Oxford University Press.

Perkins, John H. 1997. Geopolitics and the Green Revolution: Wheat, Genes, and the Cold War. Oxford University Press.

Pillai, N.G.K., P. K. Katiha, and Central Marine Fisheries Research Institute. 2004. Evolution of fisheries and aquaculture in India. Central Marine Fisheries Research Institute.

Pradhan, Dolagobinda and Flaherty, Mark. 2007. "National Initiatives, Local Effects: Trade Liberalization, Shrimp Aquaculture, and Coastal Communities in Orissa, India.” Society \& Natural Resources, 21: 1, 63 -76.

Pratt, G. and Rosner, V. 2006: Introduction: the global and the intimate. Women's Studies Quarterly 34, 13-24.

Primavera, J.H. "Overcoming the impacts of aquaculture on the coastal zone.” Ocean \& Coastal Management 49: 531.545.

Rahnema, Majid, and Victoria Bawtree. 1997. The Post-Development Reader. Zed Books.

Razavi, S. and C. Miller. 1995. From WID to GAD: Conceptual Shifts in the Women and Development Discourse. Geneva : United Nations Research Institute for Social Development.

Rius, Marisa Belausteguigoitia. 2012. "The Pedagogy of the Spiral: Intimacy and Captivity in a Women's Prison.” In The Global and the Intimate: Feminism in Our Time, 243-50. Gender and Culture. Columbia University Press.

Rivera-Ferre, Marta G. Can Export-Oriented Aquaculture in Developing Countries be Sustainable and Promote Sustainable Development? The Shrimp Case. J Agric Environ Ethics 22 (2009): 301-321.

Roche, Michael. 2010. "Historical Research and Archival Sources.” In Qualitative Research Methods in Human Geography, 3rd edition, 173-90. Ontario: Oxford University Press.

Ross, Michael L. 1999. “The Political Economy of the Resource Curse.” World Politics 51 (2): 297-322. doi:10.1017/S0043887100008200. 
Sachs, Jeffrey and Andrew Warner. 1995. "Natural Resource Abundance and Economic Growth.” NBER Working Paper 5398.

Sachs, Wolfgang. 1992. The Development Dictionary: A Guide to Knowledge as Power. Zed Books.

Saguin, Kristian. 2015. "Blue Revolution in a Commodity Frontier: Ecologies of Aquaculture and Agrarian Change in Laguna Lake, Philippines.” Journal of Agrarian Change.

Samaddar, Arindam. 2006. “Traditional and Posttraditional: A Study of Agricultural Rituals in Relation to Technological Complexity among Rice Producers in Two Zones of West Bengal, India.” Culture \& Agriculture 28 (2): 108-21.

Sayer, Andrew. 1992. Method in Social Science: A Realist Approach. Psychology Press.

Shiva, Vandana. The Violence of the Green Revolution: Third World Agriculture, Ecology and Politics. London: Zed Books, 1991.

Shiva, Vandana. 2000. Stolen Harvest: The Hijacking of the Global Food Supply. Cambridge: South End Press.

Shiva, Vandana, and Gurpreet Karir. 1996. "Towards sustainable aquaculture:

Chenmmeenkettu."

Singh, Joginder, and R.S. Sidhu. 2006. "Accounting for Impact of Environmental Degradation in Agriculture of Indian Punjab.” Agricultural Economics Research Review 19: 37-48.

SNEHA. 2009. SNEHA’s Memory Lane. Nagapattinam, India: SNEHA.

Sobha, I. 2007. “Green Revolution: Impact on Gender.” J. Hum. Ecol 22: 107-13.

Springer, Jenny. 2000. "State Power and Agricultural Transformation in Tamil Nadu.” In Agrarian Environments: Resources, Representation, and Rule in India, 86-106. Durham and London: Duke University Press.

Stickney, Robert R., and James P. McVey. 2002. Responsible Marine Aquaculture. First edition. Wallingford, Oxon; New York: CABI.

Stonich, Susan C., John R. Bort and Luis L. Ovares. 1997. Globalization of shrimp mariculture: The impact on social justice and environmental quality in central America. Society and Natural Resources: An International Journal 10(2): 161-179. 
Stonich, S.C. and C. Bailey. 2000. Resisting the Blue Revolution: Contending Coalitions Surrounding Indutrial Shrimp Farming. Human Organization 59(1): 23-34.

Swaminathan, M. S. (1996) Sustainable Agriculture: Towards an Evergreen Revolution (Delhi: Konark Publishers).

Swapan, Mohammad Shahidul Hasan and Michael Gavin. 2010. A desert in the delta: Participatory assessment of changing livelihoods induced by commercial shrimp farming in Southwest Bangladesh. Ocean and Coastal Management 54: 45-54.

The Hindu. 2015. "Shrimp Farmers Can Now Get Global Market Price Infor via SMS,” July 9, sec. Business Line.

Thirumalai, P., J. Senthil, and P.H. Anand. "Impact of Tsunami on Aquaculture Farms Along the Nagapattinam Coast Zone, Tamil Nadu, India.” Journal of the Indian Society of Remote Sensing 35, no. 1 (2007): 67-72.

UN.1995. The World's Women 1995; Trends and Statistics. New York: United Nations.

Vandergeest, Peter. 2007. "Certification and Communities: Alternatives for Regulating the Environmental and Social Impacts of Shrimp Farming.” World Development 35(7): 1152-1171.

Vasconcellos, Ana Maria de Albuquerque, and Mario Vasconcellos Sobrinho. 2015. "Institutional Development for Good Governance: The Role of Intermediary NGOs in Para State, Amazonia.” Rev. Adm. Publica 49 (3): 793-815.

Villholth, K.G., P.H. Amerasinghe, P. Jeyakumar, C.R. Panabokke, O. Woolley, M.D. Weerasinghe, N. Amalraj, S. Prathepaan, N. Burgi, D.M.D.S. Lionelarathne, N.G. Indrajith, and S. Pathirana. 2005. Tsunami impacts on shallow groundwater and associated water supply on the East Coast of Sri Lanaka. Colombo, Sri Lanka: International Water Management Institute (IWMI).

Vivekanandan, V., and J. Kurien. 1997. "Socioeconomic and Political Dimensions of Shrimp Culture Development in India: The Case of Andhra Pradesh.” In Second International Symposium on Sustainable Aquaculture. Oslo, Norway.

Warren, Carol B., and Jennifer Kay Hackney. 2000. Gender Issues in Ethnography. Second Edition. Vol. 9. Qualitative Research Methods. SAGE.

Weeratunge, N., K. A. Snyder, and C. P. Sze. 2010 Gleaner, fisher, trader, processor: understanding gendered employment in fisheries and aquaculture. Fish and Fisheries 11: 405- 420. 
Weichselgartner, Juergen, and Ilan Kelman. 2015. "Geographies of Resilience Challenges and Opportunities of a Descriptive Concept.” Progress in Human Geography 39 (3): 249-67. doi:10.1177/0309132513518834.

Whitcombe, E. (1972) Agrarian Conditions in Northern India, Volume 1: The UP Under British Rule 1860-1900 (Berkeley: University of California Press).

Whitmarsh, David and Maria Giovanna Palmieri. 2008. Aquaculture in the Coastal Zone: Pressures, Interactions and Externalities. In Aquaculture in the Ecosystem. eds. M. Holmer, K. Black, C.M. Duarte, N. Marba, and I. Karakassis. Springer.

Wood, Andrea. 2006. “'Straight' Women, Queer Texts: Boy-Love Manga and the Rise of a Global Counterpublic.” Women’s Studies Quarterly 34 (1/2): 394-414.

Wyban, James, and James N. Sweeney. 1991. Intensive Shrimp Production Technology: The Oceanic Institute Shrimp Manual. The Institute.

Yadava, Yugraj Singh. 2002. "Shrimp Farming in India -- Lessons and Challenges in Sustainable Development.” Aquaculture Authority News. 
Appendix 1 - Household Survey Guide 
Household Survey Guide

குடியிருப்புகளின் ஆய்விற்கான வழிகாட்டி

Questions:

கேள்விகள்:

1. How many members are in the household?

உங்கள் குடித்தனத்தில் எத்தனை பேர் உள்ளனர்?

2. What is the age and gender of each household member?

உங்கள் குடித்தனத்தில் உள்ளவர்களில் ஆண்கள், பெண்கள்

எத்தனை பேர் என்பதை அவர்களின் வயதுடன் குறிப்பிடவும்?

3. What is each household member's occupation?

உங்கள் குடித்தனத்திலுள்ள ஒவ்வொருவரும் என்ன

வேலை/தொழில் செய்கிறார்கள் என்பதை குறிப்பிடவும்?

4. What is your highest level of education?

உங்களின் அதிகபட்ச கல்வித் தகுதி என்ன?

5. How long have you lived in this community?

நீங்கள் எவ்வளவு காலமாக இந்தச் சமூகத்தில் வசிக்கிறீர்கள்?

6. Is your family involved in the farming of fish/shrimp?

உங்கள் குடும்பம் மீன் பண்ணை / இறால் பண்ணைத்

தொழிலில் ஈடுபடுகின்றனராஉள்ளனாா? 
7. What is your opinion about the fish/shrimp farms in your community?

உங்கள் சமூகத்திலுள்ள மீன் பண்ணை மற்றும் இறால்

பண்ணைத் தொழில் குறித்த உங்களது கருத்துக்களைக்

கூறுங்கள்?

8. What were your experiences during the tsunami of 2004 ?

2004 சுனாமியின்போது தங்களுக்கு ஏற்பட்ட அனுபவங்களைக்

கூறுங்கள்?

9. What kind of changes happened in your community as a result of the tsunami?

சுனாமியால் தங்களது சமூகத்திற்கு என்ன வகையான

மாறுதல்கள் ஏற்பட்டன?

10. What recovery efforts took place after the tsunami?

சுனாமிக்குப் பின்னர் தங்கள் பகுதியில் ஏற்பட்ட மீட்பு

நடவடிக்ககைகள் குறித்து குறிப்பிடவும்? 
VITA

\section{BRITTANY LOUISE KIESSLING}

Born, Maryland

2004-2008

B.S., Biology

Salisbury University

Salisbury, Maryland

2004-2008

B.S., Environmental Science

University of Maryland

Eastern Shore,

Princess Anne, Maryland

2009-2010

Research Assistant

Institute of Public Opinion Research

Florida International University

Miami, Florida

2009-2012

M.A., Global and Sociocultural Studies

Florida International University

Miami, Florida

2010-2016

Graduate Assistant

Florida International University

Miami, Florida

\section{PRESENTATIONS}

Kiessling, B.L. (2012) Fishing for Empowerment: The Interconnections between Commercial Aquaculture Development and Issues of Gender and Sexuality in Bangladesh. Paper presented at Graduate Student Conference, Florida International University, Miami, Florida.

Kiessling, B.L. (2015) Blue Development: Analyzing the Role of the State in the Rise of Aquaculture in India. Paper presented at Graduate Student Conference, Florida International University, Miami, Florida.

Kiessling, B. L. (November 2016) Commercial Aquaculture as a Post-disaster Development Tool in Tamil Nadu, India. Paper presented at the meeting of the American Anthropological Association, Denver, Colorado. 